\title{
Cazadores de la Puna Seca y Salada del Area Centro Sur Andina (norte de Chile)
}

LaUtaro NúÑEZ ${ }^{1}$ Y CALOGERo SANTORO ${ }^{2}$

\section{RESUMEN}

A comienzos del Holoceno, cerca de los 11000 años AP, habrían arribado los primeros cazadores andinos a los auspiciosos pero no exuberantes territorios de la Puna Seca y Salada, al sur oeste del plateau andino. Esta área de estudio comprende en la actualidad el sur de Perú, norte de Chile y suroeste de Bolivia.

En esta oportunidad presentamos una versión resumida de los datos e hipótesis que han explicado el proceso de adaptación y cambio de las poblaciones de cazadores localizados en las regiones puneñas meridionales, cuyas diferencias han sido descritas previamente por nosotros. La Puna Seca, ubicada al norte de la localidad de Lirima, habría sido favorable para los asentamientos basados en actividades de caza y recolección en torno a pisos altoandinos, accesibles durante todo el año. La ausencia de una marcada estacionalidad en la distribución y disponibilidad de los recursos no habría determinado patrones de movilidad regulares o cíclicos como ocurre con los grupos trashumantes adaptados a zonas de marcada variación estacional. Esta última condición persiste en la Puna Salada, donde la disponibilidad estacional de los recursos de caza y recolección y la imposibilidad de ocupar los pisos más altos durante el invierno habría incentivado patrones de asentamientos que se ajustan al modelo clásico de trashumancia. En efecto, muchos de los trabajos previos en el área se han caracterizado por una aplicación general del modelo de trashumancia, sin atender las condiciones y particularidades de ambas punas.

Los datos que se presentan a continuación forman parte de un corpus de hipótesis de trabajo que deberán ajustarse en el futuro en relación al avance de los estudios de caza y recolección en los Andes. Es por ahora una primera línea datum que integra a los principales episodios arcaicos con controles cronoestratigráficos en las tierras altas del norte de Chile, como referencia general para las actuales investigaciones en curso.

1 Instituto de Investigaciones Arqueológicas R. P. Gustavo Le Paige. s.j., Universidad del Norte, San Pedro de Atacama, CHILE.

2 Facultad de Estudios Andinos, Universidad de Tarapacá, Arica, CHILE.

\section{División ecológica y recursos}

a) Características generales

En el perfil ecológico entre la costa y la Puna se yuxtaponen varios nichos que integran las dos ecozonas ecológicas mayores de este estudio (Figura 1). La drástica zonación vertical no ocurre en el sentido longitudinal a lo largo de los Andes (Hester 1966: 378). Sin embargo, Troll (1958) reconoció sensibles variaciones que le permitieron definir diferentes enclaves. Conciernen en este caso las zonas Puna Seca y Puna Desértica o Salada, cuyas características se describen y discuten a continuación.

De acuerdo a la clasificación de Troll, la Puna Seca comparte rasgos con la Puna normal y se distinguen porque esta última presenta una mayor carga de humedad y la posibilidad de actividades agrícolas sobre los $4000 \mathrm{~m}$. Comparten un nivel de $5000 \mathrm{~m}$ para las nieves eternas y la posibilidad de asentamientos extremos hasta $5200 \mathrm{~m}$, constituyendo poblaciones a base de pastos. Mientras que en la Puna Desértica o Salada descienden considerablemente los límites de la agricultura y con ello las poblaciones con instalaciones permanentes (Troll 1958: 24).

En el clásico mapa ecológico de Troll, toda la región alta del Norte Grande de Chile, hasta el límite con Perú, queda incluida dentro de la Puna Salada. Una revisión más cuidadosa de las condiciones de esta zona permiten colocar el límite norte de la Puna Salada más hacia el sur, en las inmediaciones de la localidad de Lirima ( $\mathrm{ca} .20^{\circ}$ Lat. S). El área entre Lirima y la frontera de Chile con Perú queda así mejor acotado esta vez formando parte de la Puna Seca.

Hacia el sur, en lo que corresponde a la Puna Salada, hasta el Salar de Atacama (20 $26^{\prime}$ Lat. S) las condiciones de temperatura y sequedad se tornan drásticas, impidiendo una permanencia de año completo. Se accede, en consecuencia, a un nivel de alta Puna (sobre $4000 \mathrm{~m}$ ), en territorios que sólo pueden ser usados en estaciones cálidas, a base de 


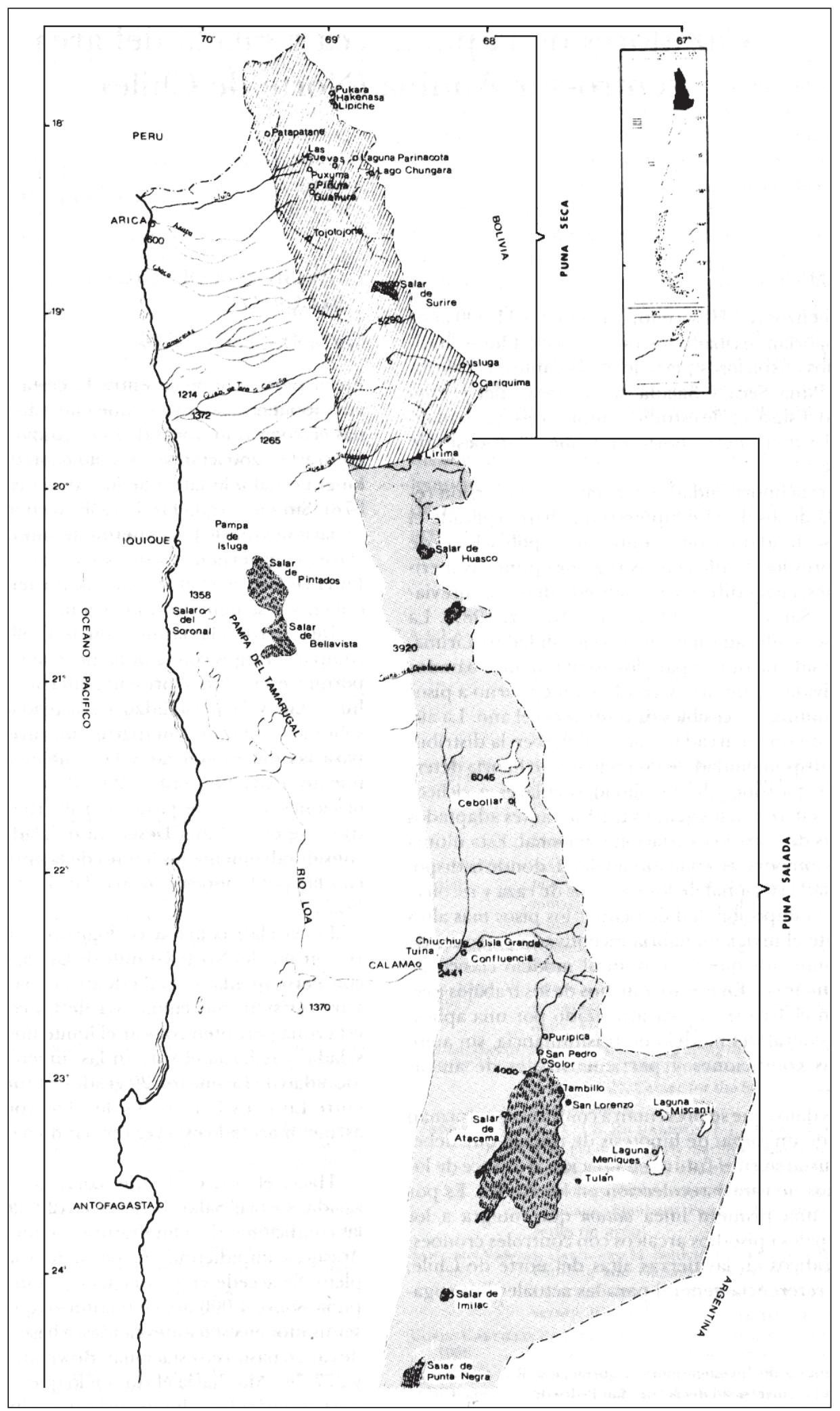

Figura 1. Mapa del área de estudio (norte de Chile), donde se destaca la Puna Seca y Salada, las referencias geográficas más relevantes y los sitios arcaicos señalados en el texto. 
actividades de caza o pastoreo estacional (Bowman 1924: 244-247, 277-278). Más hacia el sur, en lo que corresponde al norte semiárido, el límite de la agricultura desciende a $2000 \mathrm{~m}$, entonces: "la montaña como tal, es ya campo de lucha y no espacio nuclear y de sustento de culturas humanas como en los trópicos" (Troll 1958: 24).

Aparte de las diferencias climáticas, es importante anotar las diferencias ecológicas. Mientras que en la Puna Seca hay un rico ambiente forrajero apto para camélidos, complementado con animales menores, aves y roedores y ausencia de plantas con frutos comestibles; en la Puna Salada de Atacama, el ambiente forrajero es más deprimido, complementado de árboles (algarrobo y chañar) con producción para recolección y molienda en el piedemonte. Como el mayor recurso forrajero es la alta Puna y aquí no hay adaptación invernal, la avifauna presenta patrones de movilidad estacional, estimulando las prácticas trashumánticas. Estas condiciones climáticas, florísticas y faunísticas, no sólo se deben a la ubicación longitudinal, sino también influye la geomorfología vertical, cuyos perfiles ofrecen diferencias sustanciales (Figura 2). Probablemente, estas condiciones, incluyendo la frontera Cariquima-Isluga, comenzaron a estabilizarse desde el Holoceno Temprano, lo que coincide con la aparición de campamentos ubicados en espacios sobre $4000 \mathrm{~m}$ en la Puna Seca, mientras que en la Puna Salada éstos aparecen, sensiblemente en alturas más moderadas en pisos de oasis y quebradas (ca. $3000 \mathrm{~m})$.

Ciertamente, la adaptación a las ecologías de la Puna Seca y Salada imprimieron condiciones particulares a los patrones de asentamiento y circuitos trashumánticos. Por ejemplo el nivel de base regional, bajo la Puna Seca, se localiza en la cuenca de la Pampa del Tamarugal (ca. $1000 \mathrm{~m})$. Allí se agolpan las aguas subterráneas, dando lugar a los bosques de Prosopis sp. (algarrobos y tamarugos), de modo que se sitúa a algo más de $150 \mathrm{~km}$, quedando fuera de un alcance cercano de la ocupación de las tierras altas.

En reversa, el nivel de base regional, bajo la Puna Salada, se sitúa en el borde oriental de la cuenca de Atacama, a ca. $2300 \mathrm{~m}$, con aguas subterráneas que estimulan el crecimiento de bosques de algarrobos y chañares, más cercanos a las ocupaciones de las quebradas y Puna Salada. El uso de sus recursos fue más inmediato, estimulando más el acceso trashumántico.

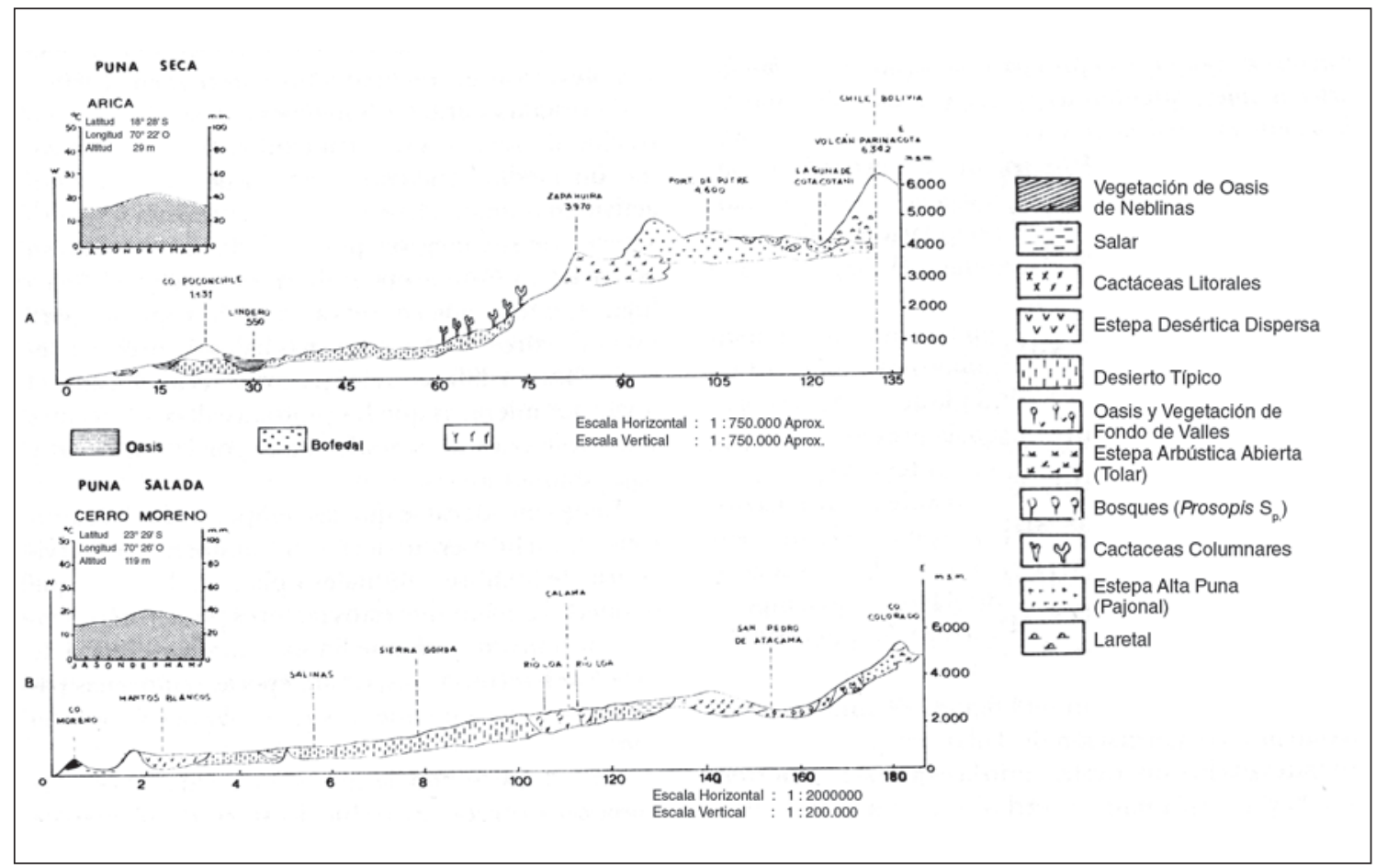

Figura 2. Transecto ecológico oeste-este, con los principales recursos vegetacionales de secciones representativas de la Puna Seca (A) y Salada (B) 
Por otro lado, debido a la distribución y cantidad de precipitaciones, la franja de vegetación de las tierras altas tiende hacia el sur a replegarse en altura en la medida que los márgenes del desierto absoluto penetran más y más hacia el interior. De esta manera, en la Puna Seca la vegetación comienza a los 1500 m mientras que en la Puna Salada ésta comienza a los $2600 \mathrm{~m}$. La incidencia de pastos más estacionales, dependientes de las lluvias de verano, también se incrementa hacia el sur (Villagrán et al. 1982: 15). Igualmente, es notorio un descenso gradual de la temperatura en la misma dirección, incrementando su efecto en sectores sobre $4000 \mathrm{~m}$; a la latitud de la Puna Salada las temperaturas se mantienen bajo el punto de congelación a lo largo del invierno. En la Puna Seca, en cambio, el período de heladas es más corto y desaparece durante el día, permitiendo la sobrevivencia de densas comunidades de plantas $\mathrm{y}$ animales.

\section{b) Puna Seca}

Morfológicamente se distinguen tres pisos ecológicos verticales en la Puna Seca (ver Figura 2): a) valles precordilleranos y praderas de interfluvio ubicados al pie del gran macizo montañoso andino (ca. 2000-3000 m); b) valles cordilleranos (ca. 3000-4000 m) y, c) alta Puna (ca. 4000-5000 m) o plateau altiplánico alterado por volcanes y montañas aisladas de hasta $6000 \mathrm{~m}$. En estos pisos altos desaparecen las estrictas condiciones áridas de la costa con el aumento gradual de la pluviosidad en sentido vertical oeste-este, partiendo de $50 \mathrm{~mm}$ de promedio anual en el piso precordillerano hasta alcanzar en la alta Puna promedios de 300 a $350 \mathrm{~mm}$. Esto define en el área condiciones marginales de desierto en oposición a las condiciones de desierto absoluto vigente en las zonas bajas costeras. Se asocian a los pisos mencionados tres zonas vegetacionales que acusan una drástica zonación vertical de acuerdo a un transecto realizado en la latitud $18^{\circ} 28^{\prime} \mathrm{S}$ (Villagrán et al. 1982).

Estas tres zonas vegetacionales se traslapan, pero no son completamente coincidentes con los pisos ecológicos definidos más arriba. Presentan las siguientes características:

1) Valles cordilleranos y praderas de interfluvio (2000-3000 m). Este piso está asociado con la "Formación Desértica" caracterizada por matorrales y arbustos tales como Atriplex microphyllum y
Ambrosia artemisloides; suculentas como cactus columnares Browningia candelaris y cactus de menor tamaño (Opuntia sp.), y algunas especies de hierbas Coldenia paronichiodes y Philippiamra fastigiata, que se ubican entre 1540-2800 m. Las precipitaciones alcanzan hasta promedios de $50 \mathrm{~mm}$ anuales (Villagrán et al. 1982).

A pesar que varias de aquellas especies tienen valores forrajeros su escasa cobertura (10\%) atrae pocos animales en la actualidad y la actividad pastoril es muy deprimida. Sin embargo, la presencia de ocupaciones arcaicas supondría la existencia de condiciones suficientemente favorables para cazadores recolectores, que consumieron camélidos, roedores y algunos tubérculos, como ha sido constatado en la cueva de Patapatane desde el Holoceno Temprano (ca. 8000-3500 AP) (Santoro y Chacama 1982, 1984).

2) Valles cordilleranos (3000-4000 m). Se asocia a este piso la "Formación de Tolar" con varias comunidades exclusivas, destacando la riqueza de arbustos y subarbustos "siempre verdes" y cadulifolios (tolas, tolillas o tolar) con predominio de Fabiana densa y Baccharis boliviensis, alcanzando un $50 \%$ de cobertura, con precipitaciones anuales promedio de 100 a $300 \mathrm{~mm}$. Esta formación vegetacional se ubica entre 2800-3800 m (Villagrán et al. 1982).

3) Alta Puna (4000-5000 m). Se asocia a la alta Puna la "Formación de Pajonal" dominada por gramíneas perennes de crecimiento en champas, paja o ichu (Festuca orthophylla); formaciones intrazonales de vegas o bofedales (Oxychloe andina y Distichia muscoides); bosquecillos discontinuos de queñoales (Polylepis tarapacana) y agrupaciones de llaretales (Azorella compacta). En promedio presenta 26\% de cobertura, pero llega excepcionalmente a $70 \%$ en los bofedales, en torno a los cuales se desarrolla una importante vida animal. Tal como ocurre en los pisos anteriores, muchas plantas son exclusivas, lo que junto a los factores de temperatura y altitud, definen una fauna especializada, con varias especies que pueden organizar su vida estable en torno a estas cuencas, constituyendo una fuente segura de subsistencia.

Actualmente, es posible encontrar en los bofedales, durante todo el año, grupos de vicuñas (Vicugna vicugna). En especial piños familiares, que comparten pequeños espacios dentro del bofedal como parte de 
un territorio mayor que tienen bajo control. Otros animales se asocian a las áreas rocosas en torno al bofedal como las vizcachas (Lagidium viscacia). Tórtolas o tortolitas bolivianas (Metropelia ceciliae), pato jergón chico (Ana flacirotis) concurren entre una larga lista de roedores y aves. En las praderas adyacentes se encuentra el cholulo (Ctenomys), el ñandú (Pterocnemia pennata tarapacensis), la kiula o perdiz de la Puna (Tinamotis pentlandii), cuya recolección de huevos ofertaron un recurso adicional (Lynch 1980).

De esta manera, los bofedales con su alta concentración de recursos de fácil explotación aparecen como un medio "eficiente" que no demandaba gran actividad humana. Este valor se incrementa si se considera que sus mejores posibilidades se encuentran en invierno (junio-septiembre), porque es el único lugar húmedo que conserva pastos apropiados para los herbívoros. En los pisos más bajos de precordillera y valles cordilleranos los pastos se secan durante el invierno; mientras que las praderas altas adyacentes a los bofedales no son afectadas por la sequedad y bajas temperaturas.

Debe considerarse que las temperaturas bajas extremas, incluso en invierno, no inhiben la supervivencia de hombres, animales y plantas; de modo que se puede concluir que estos factores pudieron provocar e incentivar, más que limitar, la convergencia de cazadores recolectores, desde épocas tempranas para establecer campamentos en cualquier época del año.

En contraste con la abundante vida animal, la Puna Seca ofrece un reducido número de plantas de recolección. Tanto los reportes botánicos como etnográficos reconocen que un alto porcentaje de la flora tiene funciones forrajeras, en cualquiera de los tres pisos (Van Kessel 1980; Kalin et al. 1982; Castro et al. 1982; Villagrán et al. 1982). Las pocas plantas de consumo humano, bayas de cactáceas y algunas hierbas del bofedal, no susceptibles de molienda, fueron posiblemente, un recurso secundario y temporal. Esto coincide con la ausencia de elementos de molienda: metates, morteros y manos, mientras no hubo productos cultivados. Estos rasgos florísticos y culturales contrastan con la situación descrita para la Puna de Atacama, donde en el Período Arcaico Tardío y Medio las actividades de molienda juegan un rol destacado en el patrón de asentamiento y actividades de subsistencia.
Esto parece vincularse en lo que concierne a la recolección de vainas de algarrobo (Prosopis sp.) $\mathrm{y}$ frutos de chañar (Geoffrea decorticans), recursos localizados cerca de las quebradas con intensa ocupación arcaica al pie de la alta Puna de Atacama, y en reversa, a la lejanía de estos recursos en relación al ambiente de la Puna Seca.

En suma, las características ecológicas y culturales de la Puna Seca contrastan con la situación de la Puna Salada, donde desde épocas arcaicas tempranas la caza y recolección estacional tuvo un rol determinante en la definición de los patrones de asentamiento y actividades de subsistencia.

\section{c) Puna Salada}

En la Puna Salada se distinguen, morfológicamente, tres pisos ecológicos (ver Figura 2): oasis y Salares (2100-3100 m); quebradas intermedias en el plateau riolítico (3100-3850 m) y alta Puna (3850-4250 m). Estos pisos presentan algunas diferencias con sus homólogos descritos para la Puna Seca. La primera diferencia corresponde a los límites verticales de la distribución zonal de las plantas que se concentran esta vez entre 3100 a $4380 \mathrm{~m}$. Bajo el límite inferior la vegetación prácticamente es ausente $\mathrm{y}$, sobre el límite superior la cobertura vegetal aparece pobremente desarrollada en lo que corresponde al nivel subnival. Los tres pisos mencionados abarcan dos zonas climáticas: a) Subandina con precipitaciones ocasionales durante el verano y, b) Andina o "alta cordillera", con precipitaciones más regulares (Villagrán et al. 1981: 5-6). Coincide, con la Puna Seca, la existencia de especies exclusivas para cada piso, muchas de las cuales se repiten, pero se distinguen en su concentración y distribución (Villagrán et al. 1981).

A continuación se presentan las formaciones vegetacionales asociadas a los tres pisos mencionados:

1. Oasis y salares (2100-3100 m). Este piso corresponde al Salar de Atacama propiamente tal. La vegetación consiste en arbustos xerofíticos de distribución espaciada con una cobertura de $2.5 \%$ (Villagrán et al. 1981: 6). Las principales asociaciones vegetacionales incluyen: Acantholipia deserticola, Ambrosia artemisloides, Helogyne macrogyne, Helioanthrocereus atacamensis (Villagrán et al. 1981). 
2. Quebradas intermedias en el plateau riolítico (3100-3850 m). Estas quebradas presentan $43.8 \%$ de cobertura vegetacional, ofreciendo las mejores potencialidades para hombres y animales dentro de la zona. Arbustos, subarbustos y especies forrajeras constituyen los componentes más destacados de la vegetación de tolar en este sector. Las principales asociaciones vegetacionales son: Fabiana densa, Baccharis boliviensis, Baccharis incarum, Junelia y Seriphioides, Lampaya medium (Villagrán et al. 1981).

3. Alta Puna (3850-4250 m). A pesar de que este piso presenta mayores precipitaciones en relación a los dos anteriores, a raíz de las lluvias de verano (200-250 mm promedio anual), ofrece una escasa cobertura vegetacional ( $10 \%)$, debido a que las bajas temperaturas inhiben el crecimiento de las plantas durante el invierno. De modo que hay pastos disponibles sólo en el verano (diciembre-marzo) y éstos constituyen la vegetación dominante y extensiva. Hacia los sectores altos de este piso se agregan plantas en cojín (Villagrán et al. 1981).

Los patrones de asentamiento en la Puna Salada debieron organizarse en torno a los recursos concentrados a lo largo de las quebradas, oasis piemontanos y vegas de la playa del Salar de Atacama. Las evidencias arqueológicas demuestran, desde épocas tempranas, un uso importante del piso de quebradas intermedias, quedando los pisos extremos como zonas complementarias de uso más estacional, situación que en general contrasta sustancialmente con la Puna Seca.

Para los efectos de comprender más localmente las variaciones de recursos vegetacionales y la distribución de fauna asociada, se debe considerar como indicador el transecto de la cuenca Tarajne-Tulan, en el extremo más meridional de la vertiente occidental de la Puna Salada o atacameña.

Mientras en las vegas y bordes del Salar de Atacama hay evidencias de capturas arcaicas de camélidos y roedores (Ctenomys fulvus), en las quebradas intermedias que inician el ascenso del plateau riolítico, junto a los camélidos abundan roedores como vizcacha y chinchilla. Pero en la medida que se asciende a las cubiertas vegetacionales estacionales de mayor extensión, la avifauna es más significativa, tal como ocurre en la alta Puna (camélidos, aves acuáticas, aves corredoras, etc.).
El examen del transecto Tulan es entonces muy útil para atender el uso complementario de pisos vegetacionales y faunísticos en términos del desarrollo de un patrón trashumántico más estricto que los casos posibles de la Puna Seca (Figura 3).

En términos de sustentación de un régimen trashumántico es conveniente conocer los indicadores ecológicos que contrastan cada piso altitudinal. En general, el área se considera como un semidesierto de altura con arbustos caducifolios de sequía, arbustos siempre verdes de hojas xerofíticas, gramíneas en champa y plantas en cojín. Globalmente la cobertura vegetacional no supera el $50 \%$, con un clímax por los $3800 \mathrm{~m}$ de altura (Villagrán et al. 1981). Así, bajo los 3850-3150 m dominan los arbustos y subarbustos. Las gramíneas en champa se disponen entre los 3800-3700 m. Sobre los 3900 m las gramíneas tienden a combinarse con las plantas en cojín. En el transecto Tulan se reconocen cuatro pisos con sus respectivos asentamientos arcaicos, asociados a recursos vegetacionales y faunísticos típicos. A continuación se resumen sus características de oeste a este:

Piso Tilocalar (2300-2380 m). Corresponde al borde oriental del Salar de Atacama, donde se localizan lagunetas con concentraciones de aves (flamencos), playas con colonias densas de cholulos (Ctenomys fulvus) y vegas extensas en las playas del Salar, tipificadas por una cobertura vegetacional de cojinetes o champas en las zonas más húmedas (vegas de Tilocalar). Pero en los alrededores de las zonas húmedas, la vegetación es menos continua con una amplia cobertura de arbustos que crecen en las planicies marginales del Salar: rica rica, cachiyuyo, pingo pingo, brea, etc.

Algunos rasgos típicos son el déficit de lluvias, más altas temperaturas, afloramientos de aguas salobres y costras, ausencia de árboles (chañar y algarrobo), la imposibilidad de implantar algún régimen de cultivos y su riqueza forrajera asociada a reducidas vertientes de agua potable. La presencia de densos depósitos de huesos de camélidos en el sitio Tambillo, ubicado en este ambiente, aunque algo más al norte, señala que existió en el pasado una relación entre estas vegas y la sustentación de camélidos. En la actualidad las vegas de Tilocalar son ocupadas por ovejeros de la localidad de Peine. 


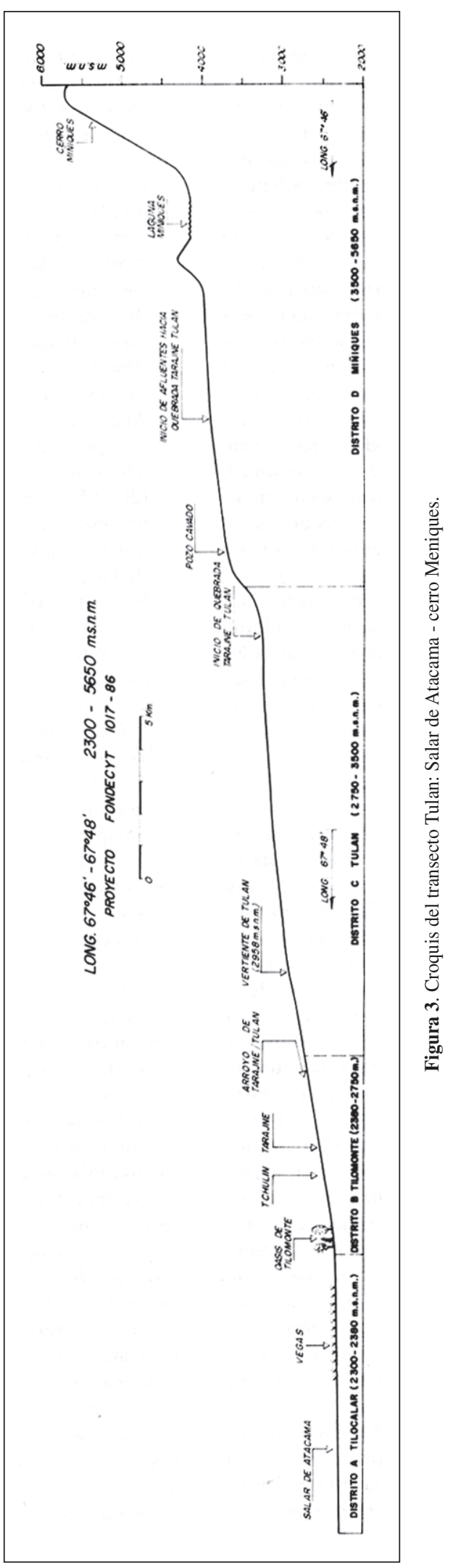

El forraje disponible en las vegas del Salar aunque es estable, tiende a ser más óptimo entre los meses de octubre, noviembre y diciembre, cuando ocurren temporadas secas que crean etapas críticas, como aquella recurrente en octubre que afecta el forraje en pisos tan ricos como Socaire; de modo que los recursos "bajos" de las vegas del Salar fueron alternativas tan importantes que dieron lugar al hábitat de Tilocalar, de larga duración en términos de secuencia. De acuerdo a estos recursos, la concentración de sitios en torno a la vega de Tilocalar se explica sólo en términos de caza y crianza de llamas.

Piso Tilomonte (2380-2750 m). Se corresponde con un sector ecológico y poblacionalmente bien acotado donde se combina el recurso inferior del arroyo Tulan y su desagüe en torno al oasis de Tilomonte con su peculiar arboleda de chañares y algarrobos y actividades agrícolas con regadío.

El uso del espacio se orientó a las arboledas y vegas locales forrajeras, sólo como recurso alternativo en períodos de crisis de pastos al interior del transecto.

No obstante, fuera del oasis y de las vegas del arroyo la cobertura vegetacional es pobre, de carácter subandino, con evidencias de arbustos leñosos y secos, más dispersos, la que pudo ser utilizada por manadas y/o rebaños de paso.

Piso Tulan (2750-3500 m). Se trata de un sector con recursos bien focalizados en el curso del estrecho arroyo de Tulan asociado a un locus poblacional arcaico bien definido, en especial aguas abajo de la vertiente que origina al arroyo.

Sobre los $3000 \mathrm{~m}$ comienza a observarse una cobertura vegetacional equivalente al "piso andino inferior" (Villagrán 1981), con arbustos, subarbustos, caméfitas, equivalente a la formación del tolar andino (Fabiana densa, Baccharis boliviensis).

El tolar concentra el mayor potencial de forraje puesto que algo más del $80 \%$ de sus plantas son útiles a los camélidos, pero como su crecimiento es estacional el uso del tolar es flexible de acuerdo a las condiciones climáticas (pingo pingo, chaca chaca, añawa, etc.). 
El acceso al tolar ocurre después de las lluvias estivales porque sus recursos forrajeros (plantas anuales de desarrollo estacional) son efímeros en términos de depender de más o menos lluvias locales. A juzgar por la evidencia de Toconce, es probable que aquí más de 10 especies forrajeras fueron útiles para los camélidos (Aldunate et al. 1981).

En los alrededores de la quebrada Tulan se desarrollan cuencas reducidas, quebradas y altiplanicies inclinadas de este a oeste con forraje estacional de baja densidad, de naturaleza seca y leñosa, aunque hay depresiones $\mathrm{y}$ colinas con sectores de mayor significado forrajero. Estas pampas fueron utilizadas como recurso complementario a las quebradas y constituyeron el talaje del paso obligado desde las quebradas hacia las vegas de mayor altura (piso Meniques).

El piso Tulan contaba a fines del Período Arcaico con los siguientes recursos forrajeros locales: pingo pingo (Ephedra), cortadera (Cortadera sp.), totora o juncos (Scirpus sp.), ojalar o chokel (Atriplex microphylla Phill) y brea (Tessaria absinthioides). Y con los siguientes recursos foráneos: paja brava (Festuca sp.), pajonal (Stipa sp.) traída desde los 3000 a 4000 m, pajas (Cyperaceae), común en la alta Puna, asociada a la alimentación de camélidos y frutos de chañar (Geoffrea decorticans) y algarrobo (Prosopis sp.).

Piso Meniques (3500-5650 m). Los recursos forrajeros se sitúan en el drenaje de Tarajne a lo largo de quebradas y pampas aledañas con algo más de potencia en relación al distrito anterior. Hay quebradas y cursos de aguas que sostienen vegetación arbustiva permanente que aún sirven como estancias. Pero en general, en el plano inclinado ignimbrítico que asciende hasta la alta Puna los recursos de quebrada son de baja densidad porque gradualmente la cobertura vegetal de interfluvio se incrementa hasta alcanzar un área de forraje sostenido, con más incremento de lluvia estival.

El componente típico de este piso son las lagunas Miscanti y Meniques en donde la población arcaica también configuró un locus relevante. No se ha realizado una prospección intensa en este piso, pero las evidencias señalan que los sitios se ubican en quebradas con recursos forrajeros, como estaciones de paso entre los hábitats más eficientes en torno a la aguada Tulan $(2900 \mathrm{~m})$ y las lagunas referidas (4200 m).
Domina el régimen de la alta Puna (estepario de altura) con alta fluctuación de temperatura entre el día y la noche, bajo registros de hasta $-10,-20^{\circ} \mathrm{C}$, con días despejados y asoleados. Las lluvias ocurren en verano ( $c a .200 \mathrm{~mm}$ anuales), dando lugar a una cubierta esteparia de pastos duros (ichus) y tolares (Baccharis sp.). Estos recursos asociados a vertientes potables dispuestas en el paisaje altoandino permiten hasta hoy el acceso de pastores a las lagunas y vegas forrajeras, donde practican la recolección de huevos de parina y caza eventual en las estaciones cálidas. Tal situación no debió ser muy distinta al modo de ocupar temporalmente la alta Puna por los cazadores arcaicos de los pisos más bajos, en torno a la caza de camélidos, suris, etc., puesto que aquí existe una cobertura de gramíneas dominante a través de extensivos pajonales estacionales. No obstante, sobre los $4250 \mathrm{~m}$ los recursos se debilitan y se transforma el paisaje en un semidesierto de altura.

En términos generales, los recursos de este piso mantienen una biomasa mayor comparada con los anteriores en relación a la sustentación de avifauna. El listado más útil para el consumo es el siguiente: Mamíferos: vicuña (Vicugna vicugna), guanaco (Lama guanicoe), zorro (Pseudalopex culoacus), vizcacha (Lagidium viscacia), chinchilla (Chinchilla chinchilla), sarteneja (Ctenomys sp.), gato montés (Oreaylurus jacobita). Aves: suri o avestruz (Pterocnemia pennata tarapacensis), kiula (Tinamotis pentlandi) o perdiz grande, tórtola cordillerana (Metriopelia melanoptera melanoptera), canarios de cordillera, chorlo de la Puna, etc. Aves acuáticas: parina o flamenco (Phoenicopanus sp.), guayata (Chloephaga melanoptera), ajoya o tagua gigante (Folica gigantea), huairavo (Nycticorax N. tayazuguira) y gaviota andina (Larus serranus). Como estas comunidades no tienen capacidad de hibernación, deben alejarse de sectores más altos.

Entre los pisos Tulan y Meniques y sus zonas aledañas, los recursos forrajeros que nuclean las labores de caza están en quebradas, vegas y pampas de interfluvio con concentraciones en los abrevaderos. Es probable que al igual que en Toconce (Aldunate et al. 1981), más del 60\% de las especies vegetales sean forrajeras, concentradas mayormente en la formación del tolar y en menor grado en los estrechos recursos de las quebradas. Así, la mejor vía posible para sostener poblaciones arcaicas con alta densidad, como ocurre en este transecto era a través de una fina percepción de la variabilidad 
estacional y la consecuente disposición de recursos en distintas estaciones a lo largo de todo el perfil entre $\operatorname{los} 2300$ a $5000 \mathrm{~m}$.

Las diferencias que se han reseñado entre ambas punas ejerce una notable influencia en la definición de los patrones de asentamiento. Estas distinciones afectaron el énfasis en el tipo de actividad de subsistencia, la organización de los circuitos y patrones de asentamiento con diferentes centros gravitacionales. El primer autor (1980b y 1981) usando datos arqueológicos, climáticos y zoológicos ha documentado, para el Arcaico Tardío, la hipótesis de un modelo de trashumancia de caza y recolección, netamente estacional entre el Salar y la Puna alta de Atacama, con hábitats permanentes en el piso de quebradas intermedias, con desplazamientos estacionales hacia el piso de la alta Puna, sobre los 3800 m. Así, se ampliaron considerablemente los postulados de Niemeyer y Schiappacasse (1976). Mientras que en las tierras altas de Arica hemos sugerido como hipótesis, un patrón de caza con hábitats permanentes en el piso alto andino (4000-4500 m), con menor presión o determinación estacional (Santoro y Chacama 1984).

Sin embargo, estas diferencias ecológicas y sus posibles patrones de asentamiento no repercutieron en las respuestas tecnológicas. Schiappacasse y Niemeyer ya señalaron que la Puna es un factor de unificación cultural, basados en: "la semejanza tipológica del material lítico del salar de Surire con los materiales de los salares más meridionales" (1975: 55). Otro tanto ha ocurrido con ciertos tipos de puntas tempranas, recogidas en la Puna de Arica, de formas similares a las registradas en los Andes Centrales (Santoro y Chacama 1982; Lynch 1986: 155).

Podría sugerirse que la unidad ambiental de los Andes en los términos expresados por Hester (1966) habría incentivado tempranamente a cazadores de los Andes Centrales a explorar estas punas meridionales de aspecto parecido. Estos mismos cazadores o sus descendientes aprendieron rápidamente las particularidades de la Puna Seca y Salada, por lo que readaptaron sus patrones de asentamiento más que sus respuestas tecnológicas.

\section{Condiciones paleoclimáticas}

Mientras en la costa las condiciones de aridez se han mantenido por varios millones de años (Craig
1982), en la Puna la situación ha sido más dinámica no sólo durante el Pleistoceno sino también en el Holoceno (Craig 1985). Los ambientes andinos variaron sustancialmente cuando las masas de hielo se replegaron a los niveles actuales, habilitando amplias praderas donde se concentraron plantas y animales. Esto ocurría al final del Pleistoceno y Holoceno Temprano, atestiguado por campamentos de cazadores que adoptaron como propias, distintas regiones a lo largo de los Andes.

Las imágenes satelitales analizadas a la luz de modelos teóricos climáticos generales y la correlación de datos correspondientes a otras regiones, constituyen la fuente principal con que se han intentado reconstruir las fluctuaciones climáticas locales.

De esta manera, se ha sugerido que un dominio climático más húmedo y frío hacia el final del Pleistoceno y comienzo del Holoceno habría sido causado por un desplazamiento latitudinal de masas de aire dominantes o por migraciones del frente polar. De esta manera, el clima del norte de Chile habría sido favorecido por condiciones más húmedas y frías, comparables al régimen de lluvias que hoy existen en la latitud de La Serena (Lynch 1986: 148). Otros autores señalan que la falta de hielos continentales en Sudamérica habría inhibido fenómenos de ese tipo, por lo tanto, el modelo de circulación atmosférica durante el último glacial fue igual que en el presente (Nogami 1982: 47). El clima del Pleistoceno fue, en consecuencia, el efecto de un enfriamiento atmosférico que habría provocado una disminución de la evaporación, aumentando las posibilidades de humedad para el suelo y la flora (Nogami 1982: 45).

Por otra parte, se han observado niveles más altos en los lagos pleistocénicos andinos que no reflejarían la existencia de verdaderos "pluviales" en condiciones climáticas distintas a las actuales. Esto más bien podría interpretarse como una intensificación de las lluvias de verano dentro de condiciones similares a las del presente. Esta situación, a su vez, se vio favorecida por el régimen de temperaturas más bajas que habrían mantenido una mayor disponibilidad de agua sin necesidad que ocurrieran cambios climáticos mayores (Ochsenius 1986: 40).

Las condiciones finipleistocenas en la Puna Seca y Salada parece que sostuvieron ciertos locus de megafauna eventualmente asociados a cazadores 
paleoindios aún no identificados (Núñez 1983a; Santoro 1987). Por otro lado se sabe que ciertos équidos hoy extintos existían en la Puna de Jujuy (Barro Negro) por los 12000 AP (Fernández 1986). De acuerdo a los estudios polínicos en El Aguilar (Markgraf 1985), existieron eventos paleobotánicos localizados en la Puna argentina (4000 m). Estos señalan que antes de los 10000 años AP las cubiertas de herbáceas y compuestas eran más diversas, constituyendo una vegetación de tipo páramo, es decir, con más potencial forrajero que la vegetación tipo Puna.

De acuerdo a Markgraf (1985), durante el Holoceno se distinguen tres fases paleoclimáticas. Entre 10000 a 7500 AP se advierte una alta proporción de gramíneas, pero menos frecuencia de compuestas y herbáceas, similando a la vegetación altoandina. Tal situación plantea un incremento de continentalidad con inviernos más fríos que antes. Entre 7500 a 4000 AP los componentes prepuna aumentan (Ephedra, Chenopodineae/Euphorbiaceae y otros), lo cual sugiere un incremento del régimen de aridez en relación a la fase anterior (disminución de las lluvias de verano). Entre $4000 \mathrm{AP}$ a tiempos recientes las condiciones modernas se establecen con ciertos componentes de páramo, es decir, con más humedad en relación a la fase anterior, pero se plantea que los componentes de prepuna estaban lo suficientemente presentes como para advertir que continuaban las sequías de verano.

La referencia paleoclimática más cercana a nuestra área de estudio proviene de Sajama (4650 m) (Ybert y Miranda 1984). Sus resultados sugieren un clima frío y seco para una primera fase datada entre ca. 7500 a 6000 AP. La segunda fase datada entre ca. 6000-3500 AP presentaría condiciones más frías y húmedas. La tercera fase entre $c a$. 3500-2000 AP presentaría un clima frío y seco, seguido de condiciones climáticas como las actuales.

Esta secuencia se contrasta con los diagramas de polen obtenidos a $50 \mathrm{~km}$ de Escona al noreste del lago Titicaca, en el borde de Perú con Bolivia. Se sugieren condiciones secas y frías entre 10000 a $6500 \mathrm{AP}$, en un contexto de calentamiento lento con lapsos de sequías durante la Fase I. En la Fase II, por los 6000 AP siguió un incremento de la temperatura y mayor humedad. Desde $5500 \mathrm{AP}$ al presente se dispone la tercera fase con la extensión de la estepa altoandina, correspondiente a un clima de alta montaña más húmedo, lo que se podría identificar con las características de la Puna normal (Graf 1981: 367). No obstante, esta tercera fase postglacial, de acuerdo a la recurrencia de polen correlacionado en la zona de Paniri (Loa Superior), admite la posibilidad de que la III Fase de Graf pueda tener vigencia en el extremo más septentrional de la Puna Salada (C. Villagrán com. pers.).

Probablemente el esquema obtenido por Graf tiene mayor validez para la Puna Seca y Salada, puesto que por sobre las diferencias climáticas graduales que ocurren en el presente, entre la Puna normal (área del Titicaca) y las punas del norte de Chile, el clima en el pasado debió depender de los mismos factores generales que hoy día determinan el clima en toda esta región. Estos factores son: a) la corriente de convergencia intertropical, situada en latitudes del Ecuador, responsable de la humedad procedente del noreste $y, b$ ) un frente polar que trae precipitaciones desde el suroeste (Gomes y Little 1981, cit. en Kalin et al. 1988). Sin embargo, la referencia local de Sajama perturba el intento de definir secuencias paleoclimáticas regionales.

Al disponer los escasos datos paleoclimáticos locales con aquellos provenientes de regiones relativamente limítrofes, no se advierte una distribución homogénea o equivalencia de eventos y condiciones ambientales (Tabla 1). En efecto, la carencia de columnas locales con registros geocientíficos y polínicos, de valor cronoestratigráfico, no nos permite correlacionar con más confiabilidad la ocupación de las primeras fases arcaicas en relación a eventos paleoclimáticos específicos.

Es probable que los primeros poblamientos arcaicos (Fase Tuina) accedieron al territorio in toto cuando aún prevalecían las condiciones de páramo y mayor cobertura forrajera (Holoceno Temprano). Las fases siguientes debieron reajustarse a los cambios posteriores al décimo milenio AP, con la instauración de la vegetación altoandina, con frío invernal y condiciones de calentamiento gradual e interferencia de lapsos de sequías. El aumento de un régimen de aridez entre 7500 a 4000 AP pudo incentivar las labores de caza y colecta más especializada, en un marco de mayor confiabilidad en términos de domesticación de plantas del complejo cordillerano y control inicial de camélidos. Así, cuando las condiciones modernas fueron establecidas por los 5500 a 4000 AP, ya se habrían arraigado los primeros 


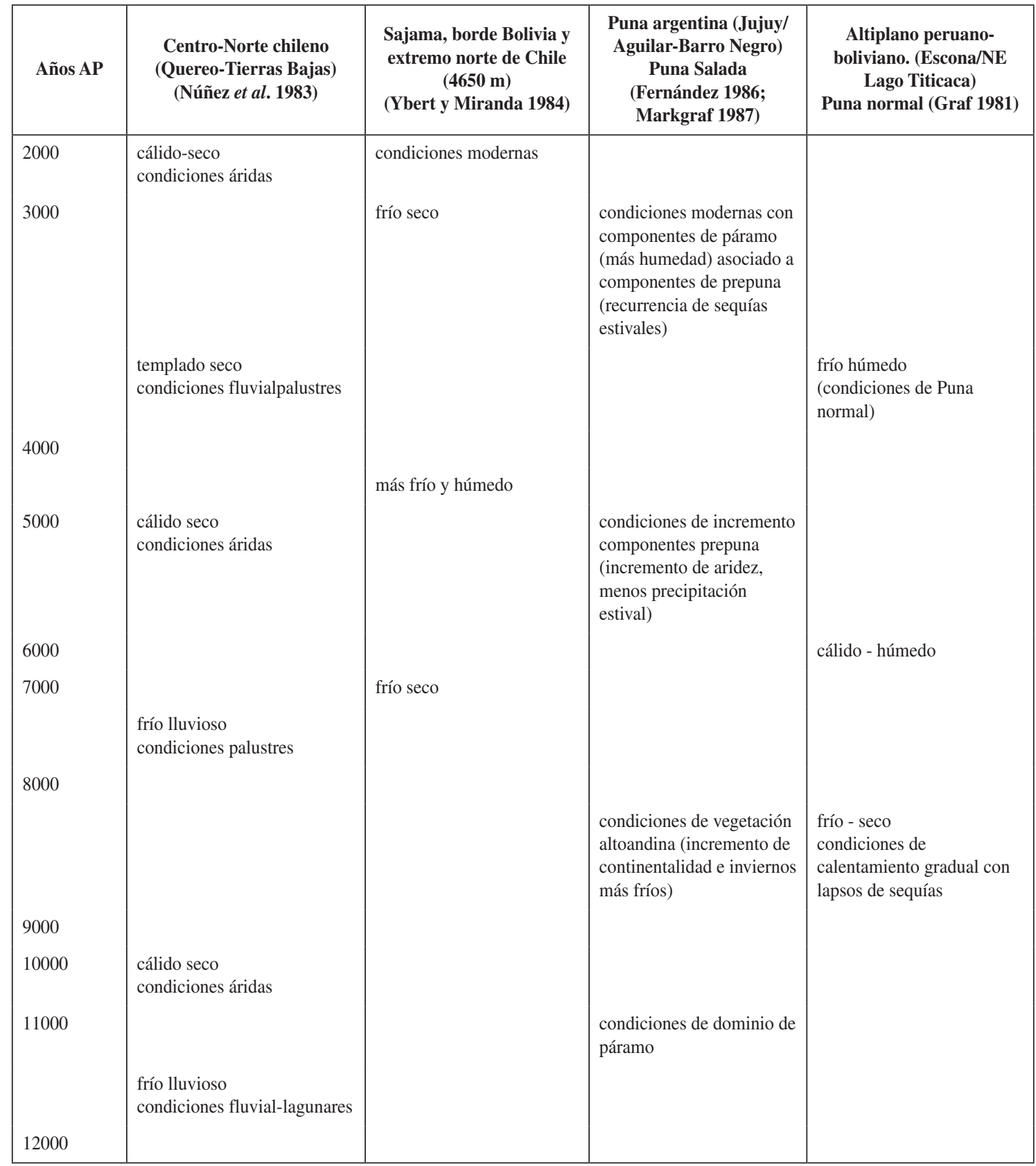

Tabla 1. Comparación de registros paleoclimáticos.

brotes de producción de alimentos cárneos y cultivados (tuberosas y Chenopodium en lo principal). Estas proposiciones deben ser comprendidas como hipótesis tentativas.

En consecuencia, de los factores que pudieron influir en los cambios climáticos postglaciales pueden esperarse distintos patrones de fluctuaciones climáticas, en términos de cambios de temperatura y humedad, de acuerdo a las particularidades de cada región, tal como ocurre en el presente entre la Puna Seca y Salada. Mientras tanto es preferible esperar datos provenientes de estas áreas para análisis paleoclimáticos más concluyentes (Tabla 1).

\section{Historia de la investigación}

Hace poco más de 40 años Bird (1943: 183, 186) sugería que los cazadores recolectores de esta 
región seca y Salada de los Andes habrían tenido posibilidades de vida a lo largo de la costa y desembocadura de ríos. Más aun, supuso que herbívoros como el guanaco debieron estar confinados a los valles bajos y, por esta razón habrían tenido escasas posibilidades de sobrevivir ante la aparición de los cazadores.

Actualmente, a pesar que no existe un conjunto suficiente de datos ecológicos, culturales y paleoecológicos se han avanzado varias hipótesis y sugerencias para explicar la adaptación y dominio de las sociedades de cazadores recolectores sobre las tierras altas de los territorios actuales del norte de Chile y sur de Perú.

Los datos estudiados por el primer autor (1981) permitieron sugerir un modelo de ocupación estacional que ha denominado "proceso de andinización" para referirse a la adaptación creciente a los ambientes de tierras altas de Atacama, desde el Holoceno Temprano, a base de una evaluación cronoestratigráfica. Esto representa un avance respecto de las interpretaciones y periodificaciones basadas en el estudio de colecciones de superficie bajo el supuesto errado que tipología es cronología (Le Paige 1970; Johnson 1978; True y Crew 1980).

Por su parte, más recientemente el segundo autor (1986) ha señalado que las particularidades de los componentes ecológicos y culturales que estructuran el modelo de "andinización" implica mayor variabilidad, en donde el rol estacional fue más significativo en la Puna Salada. En la Puna Seca, en cambio, en la parte más extrema del norte de Chile $\left(18-20^{\circ}\right.$ Lat. S) aquellos componentes habrían estructurado un modelo adaptativo algo distinto al mencionado anteriormente, es decir, con más estabilidad ocupacional en las tierras altas.

El análisis comparativo presentado ha servido de base para subdividir las tierras altas occidentales del Area Centro Sur Andina en dos zonas: la Puna Seca y la Puna Salada o Desértica de acuerdo a las categorías de Troll (1958). Desafortunadamente, Troll excluyó la Puna Seca de esta región de los Andes, clasificando todo el norte de Chile dentro de la categoría de Puna Salada o Desértica. Este criterio ha sido erróneamente reiterado en la literatura arqueológica, lo que ha llevado, salvo algunas excepciones, a la tendencia de considerar el área de estudio como una sola subárea ecológica. Las diferencias entre la Puna Seca y Salada se deben al efecto de una mayor pluviosidad en la primera y la ausencia de temperaturas extremas durante el invierno, favoreciendo ambientes más ricos y auspiciosos en comparación con la mayor inhospitabilidad de la segunda. Así, por ejemplo, la existencia de un rico piso de pastizales soporta una mayor densidad y más estable población de camélidos en la Puna Seca durante todo el año, lo que no ocurre en la Puna Salada.

Los primeros estudios arqueológicos de adaptaciones arcaicas en las tierras altas no sólo consideraron a esta región como una unidad ecológica, sino también como zona complementaria para adaptaciones centradas alrededor de las tierras bajas, especialmente la costa. Esta visión queda sugerida en las interpretaciones de las pioneras excavaciones estratigráficas de Ravinés $(1967,1972)$ en Toquepala y Caru en la sierra sur de Perú. Más tarde se postuló que los cazadores andinos habrían derivado hacia adaptaciones costeras especializadas, de acuerdo a un sitio de la costa del extremo norte de Chile (Alvarez 1980: 1029; Dauelsberg 1982: 38).

Hipótesis y planteamientos más críticos se debatieron en los 60 (Montané 1972; Núñez 1980a; Lynch 1983) a pesar de la incidencia de los estudios orientados a determinar secuencias tipológicas de industrias superficiales. Estas nuevas hipótesis se centraron en torno al patrón de movilidad tras-humántico, esbozado preliminarmente para los Andes por Lanning (1963: 262) y más claramente definido por Lynch (1967a, 1967b, 1971, 1973).

Con anterioridad y en forma independiente, Niemeyer y Schiappacasse (1963: 142-143) habrían sido los primeros en Chile en sugerir los factos involucrados con la definición de un modelo regional de trashumancia, partiendo de evidencias etnográficas (Davis 1963). En un territorio que hoy reconocemos como ideal para el desarrollo de un estilo de caza y recolección más regulado por las variaciones estacionales (Puna Salada), los autores antes citados $(1975,1977)$ sugirieron la posibilidad de conexiones trashumánticas entre la alta Puna y los oasis piemontanos.

Más recientemente, con datos más elaborados, Niemeyer y Schiappacasse (1984: 176-177) han tratado de explicar un modelo alternativo, vinculado con elementos traídos desde las tierras altas, 
encontrados en sitios de la costa (quebrada de Camarones), de acuerdo a la propuesta de Cashdan (1983) basada en el "control social de la territorialidad". Los autores aplicaron este modelo para postular un eventual intercambio de territorios entre grupos distintos de cazadores recolectores adaptados a tierras altas y bajas, respectivamente, lo que permitió a cada uno de ellos el acceso directo a recursos localizados en espacios alejados de sus hábitats originales.

Aunque la hipótesis es plausible, se debe ser prudente ante la aplicación de modelos etnográficos africanos para interpretar y reconstruir sociedades andinas tempranas (Lee y Devore 1968).

Para la interpretación de datos arqueológicos a través de "principios generales de organización" (Bailey 1983: 4) obtenidos de fuentes etnográficas, el caso de los grupos ona y yámana de Tierra del Fuego presentan tal vez más ventajas metodológicas y teóricas para el estudio de los estilos de caza y recolección entre la sociedad arcaica del norte de Chile (Santoro 1987: 12-13; Gusinde 1920: 9-10). Tal acercamiento será expuesto en estudios posteriores.

El modelo de trashumancia en los Andes fue sugerido sobre la base de la variedad de recursos complementarios jalonados en sus dos vertientes, alternados estacionalmente, entre el llamado "invierno" andino entre octubre a abril (húmedo entre enero a marzo), versus la temporada húmeda-brumosa de la costa entre mayo a septiembre. Se asumió, en consecuencia, que los cazadores ubicaron sus campamentos base en la costa entre mayo a septiembre y subieron, temporalmente, a la Puna durante el verano o "invierno andino". También se supuso que las condiciones de la Puna fueron extremadamente drásticas durante el invierno (mayo-septiembre), para permitir la permanencia de hombres y animales (Lynch 1967a, 1980).

Con el inicio de estudios locales, surgieron observaciones y ajustes al modelo general (Le Paige 1975; Núñez 1975; Núñez et al. 1975). Sin embargo, el concepto continúa usándose en sus términos fundamentales, a pesar que no sólo ha sufrido modificaciones (Lynch 1980: 4-5, 1981: 223-224), sino también ha permitido el desarrollo de posiciones teóricas opuestas que han enriquecido la discusión y análisis del problema (Cardich 1980; Rick 1980-1983).
En este contexto, desde la perspectiva de los Andes Centrales se ha sugerido que áreas periféricas como el sur de Perú y norte de Chile, con marcados ciclos estacionales habrían incentivado el desarrollo de patrones de trashumancia estacional entre la costa y la Puna. Sin embargo, aunque el balance general de los estudios de trashumancia tiende a confirmar dicha hipótesis en sus términos generales, un análisis detallado de los datos demuestra la necesidad de establecer ciertas limitaciones "locales".

Primeramente, pueden señalarse las reales y hasta escépticas conclusiones publicadas en los años 70, que señalaron la dificultad de comprobar arqueológicamente patrones de movilidad entre la costa y la Puna. Esto se debió, por un lado, a la incompatibilidad de comparar los tipos de instrumentos producidos en ambas zonas. Se reconoció también que no se contaba con suficiente información contextual y cronológica en los pisos altos. En consecuencia se estableció que la hipótesis de un patrón de trashumancia de largo aliento requería del acopio y análisis de nuevos datos (Núñez 1975; Núñez et al. 1975; Schiappacasse y Niemeyer 1975; Serracino 1975 ss.; Niemeyer y Schiappacasse 1977). Al mismo tiempo, se planteó la hipótesis involucrada con el desarrollo de patrones de movilidad estacional restringidos al interior de zonas ecológicas mayores, como la costa, considerando su amplia variedad de recursos complementarios disponibles horizontalmente, como en los oasis aledaños contrastados más verticalmente.

De esta manera, se han reconocido varios circuitos de trashumancia al interior de áreas ecológicas mayores, con recursos complementarios, tanto en términos de subsistencia como de obtención de materias primas, donde los campamentos bases pudieron ubicarse a no más de uno o dos días de camino de los campamentos temporales. Esto podría corresponder, por ejemplo, a los circuitos de TilivichePampa del Tamarugal y costa inmediata (Núñez y Moragas 1977-78), costa-quebrada Camarones (Schiappacasse y Niemeyer 1984), alta Punaquebradas-oasis de la Puna de Atacama (Núñez 1980b, 1981), quebrada Tarapacá-Pampa del TamarugalPisagua (Núñez et al. 1975; True y Crew 1980; True y Gildersleeve 1980), y quebradas o valles cordilleranos (3000-4000 m) en relación a la alta Puna (seca) (Santoro y Chacama 1984). Los intentos de explicar los patrones de asentamientos de cazadores recolectores tienen como denominador común la idea 
de desestimar la potencialidad y hospitabilidad de la Puna Seca (extremo sur de Perú y extremo norte de Chile) como hábitat de ocupación de año completo (True 1975), al confundirla con las condiciones de las tierras altas de la Puna Salada, donde es imposible vivir durante los meses de invierno -mayo, septiembre (Bowman 1924; Núñez 1980b, 1981).

La diversidad de argumentos desprendidos de un cuerpo de datos todavía no muy denso demuestra que los intentos por comprender los modos de vida de los cazadores recolectores en "las punas" (Seca y Salada) del Area Centro Sur Andina descansan sobre hipótesis plausibles que requieren de mayor acopio y análisis de datos no sólo arqueológicos sino también faunísticos, florísticos, climáticos y ecológicos. A continuación se presentan en forma sumaria, las evidencias arqueológicas locales para continuar avanzando en la hipótesis de la existencia de patrones de trashumancia nucleados dentro de subáreas ecológicas más acotadas como la Puna Seca y Salada, quedando como elemento secundario en el análisis la interacción entre estas zonas y aquéllas más distantes que, en conjunto, requieren de mayor contrastación empírica.

\section{Secuencia cronológica-cultural y patrones de asentamiento}

Se presenta a continuación una descripción sumaria de los sitios conocidos y publicados con excavaciones estratigráficas y dataciones radiocarbónicas de la Puna Seca y Salada. Se ordenan en una secuencia que incluye los períodos Paleoindio, Arcaico Temprano, Arcaico Medio y Arcaico Tardío (Tabla 2).

\section{a) Período Paleoindio (12500?-11000 AP)}

Hasta la fecha no se han registrado ocupaciones para este período. Se han encontrado restos de un milodontino en la Puna de Arica (Santoro y Chacama 1982: 31) pero sin ningún tipo de asociación humana. Este tipo de megafauna, probablemente, no tuvo un gran impacto entre los cazadores paleoindios de los Andes, quienes prefirieron los camélidos (Craig 1985). Sin embargo, se ha sugerido para las tierras altas la existencia de enclaves potenciales como hábitats para cazadores paleoindios de reducida magnitud demográfica (Núñez 1983a).

Futuras exploraciones arqueológicas en la Puna Seca deberán concentrarse en cuencas de alturas moderadas dentro de la alta Puna (ca. $4000 \mathrm{~m})$ como el Salar de Surire, Pampa Paquisa, etc. (Craig 1984). En tanto que, para la Puna Salada, la experiencia parece indicar que deberá continuarse explorando pisos más bajos en ambientes de Salares, oasis y quebradas, no olvidando las grandes cuencas bajas asociadas a bosques de Prosopis a nivel del territorio árido in toto.

\section{b) Período Arcaico Temprano (ca. 11000- 8000 AP)}

Hemos definido dos fases o patrones adaptativos para este período. El más antiguo está representado en la Puna Salada y se denomina Fase Tuina (Núñez 1983b). El otro, más reciente, se localiza en la Puna Seca, denominado Fase Patapatane (Santoro 1986). Estos dos momentos están desfasados en el tiempo, lo que puede deberse más a limitaciones de las ocupaciones registradas que a condiciones particulares de los propios patrones de asentamiento (Tabla 3).

\section{Puna Salada. Fase Tuina 11000-9500/9000 AP}

Esta fase se ha localizado, hasta el momento, sólo en la Puna Salada, en sitios de alturas moderadas (ca. $3000 \mathrm{~m}$ ): Tuina, San Lorenzo y Chulqui. Se caracteriza por un patrón de asentamiento de movilidad moderada (trashumancia inicial) adaptado a los ambientes holocénicos tempranos de la vertiente occidental de los Andes, bajo un patrón de asentamiento cuya movilidad representaría tal vez un nivel "semitrashumántico".

En la vertiente oriental de la Puna Salada, grupos de baja densidad explotaron desde quebradas abrigadas distintas ecozonas de altura, incluyendo la alta Puna y la selva oriental, dándole una mayor amplitud inicial al patrón trashumántico. Estas evidencias corresponden a los habitantes de la cueva de Huachichocana III (3400 m) quienes, aunque cazaban roedores y guanacos, intensificaron la recolección de bulbos, raíces, tuberosas, leguminosas, gramíneas, etc. Utilizaron artefactos como raspadores, unifaces y puntas triangulares asociadas a escasas foliáceas datadas en 10200-8420 AP. También destacan artesanías complejas de cuero y fibra vegetal (Fernández Distel 1974).

Otra ocupación, de esta misma naturaleza, se reconoce en Inca Cueva 4 (3600 m) en el área de Jujuy. Se repiten las puntas triangulares, raederas y raspadores de cuero, junto a sofisticadas artesanías de fibras 
para cordelería y cestos plaited. La presencia de arte rupestre, como expresión de un alto desarrollo creativo, está mejor documentado que en Toquepala, con fechas que también se remontan al noveno milenio AP (Aschero 1985).

El sitio Tuina 1, alero ubicado en la serranía del mismo nombre cerca de Calama (2800 m), presenta fechas de $10820 \mathrm{AP}$, procedente del estrato IV o inicio de ocupación y 9080 AP (sin referencia, probablemente del estrato II) obtenida por la misión de la Universidad de Columbia-Universidad del Norte (Tablas 2, 3 y 8). Correspondería a cazadores que ocuparon serranías de alturas moderadas, con posibles desplazamientos estacionales hacia la alta Puna que incluían la obtención de obsidiana. La ocupación, probablemente, ocurrió bajo un clima seco que fue haciéndose más cálido; datado por Graf-Meir (1977) entre 10000-8200 AP, en las turberas postglaciales de la Cordillera Real y Tres Cruces en el altiplano boliviano. La serranía y pampas de Tuina presentan abundante forraje andino y varias vertientes que concentraban fauna herbívora (camélidos) y roedores. Por otro lado, se ha observado que la línea de nieve y de precipitaciones locales eran más bajas que las actuales. Ambos factores habrían presionado a los cazadores a radicarse temporalmente en torno a estos enclaves de alturas tenues, restringiendo la ocupación de la alta Puna atacameña (Núñez 1984 Ms).

Los artefactos fueron elaborados en pequeños talleres cercanos a las vertientes, utilizando especialmente toba desvitrificada y felsita local. La escasa presencia de artefactos de obsidiana intrusiva habla a favor de ciertos desplazamientos estacionales hacia la alta Puna, donde se localizan los únicos recursos disponibles en el transecto. Estos movimientos debieron ocurrir en primavera y verano pero nunca en invierno debido a las bajas temperaturas (Núñez 1984 Ms).

El asentamiento se estableció en torno a un gran bloque caído, detectándose un depósito de desperdicios bajo el alero y otro inmediatamente afuera, en el límite norte. Se identificaron cuatro estratos, con una profundidad de $35 \mathrm{~cm}$ promedio, que contienen huesos de camélidos y roedores, fogones, desechos de percusión, artefactos usados y algunas preformas. Los estratos IV (inicio ocupación) y II corresponderían a un mismo patrón ocupacional, dada la presencia de artefactos similares, separados

\begin{tabular}{|c|c|c|c|c|c|}
\hline \multirow[b]{2}{*}{ Años AP } & \multirow[b]{2}{*}{ Períodos } & \multicolumn{2}{|c|}{ Puna Seca } & \multicolumn{2}{|c|}{ Puna Salada } \\
\hline & & $\begin{array}{c}\text { Patrón de } \\
\text { asentamiento }\end{array}$ & $\begin{array}{c}\text { Fase } \\
\text { cultural }\end{array}$ & $\begin{array}{c}\text { Patrón de } \\
\text { asentamiento }\end{array}$ & $\begin{array}{c}\text { Fase } \\
\text { cultural }\end{array}$ \\
\hline $\begin{array}{l}2000 \\
4000\end{array}$ & $\begin{array}{l}\text { Formativo } \\
\text { Transicional }\end{array}$ & & & & \\
\hline \multicolumn{6}{|c|}{ 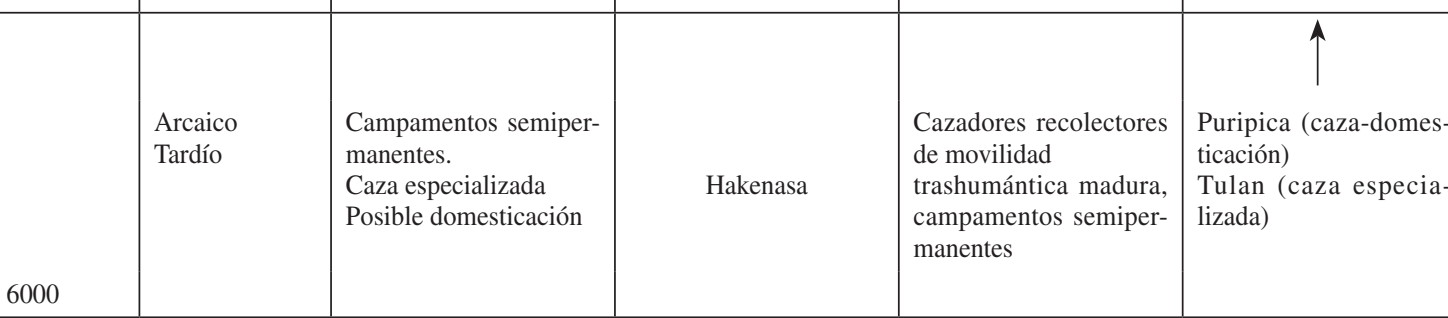 } \\
\hline 8000 & $\begin{array}{l}\text { Arcaico } \\
\text { Medio }\end{array}$ & & Asana? & $\begin{array}{l}\text { Cazadores recolectores de } \\
\text { movilidad trashumántica. } \\
\text { Campamentos expuestos } \\
\text { semipermanentes. }\end{array}$ & Tambillo \\
\hline $\begin{array}{l}10000 \\
11000 \\
\end{array}$ & $\begin{array}{l}\text { Arcaico } \\
\text { Temprano }\end{array}$ & $\begin{array}{l}\text { Cazadores semitrashu- } \\
\text { mantes nucleados en torno } \\
\text { a la ecozona de Puna en } \\
\text { refugios restringidos. }\end{array}$ & $\begin{array}{c}\text { Patapatane } \\
\text { Tuina? }\end{array}$ & $\begin{array}{l}\text { Cazadores rccolectores, } \\
\text { movilidad trashumán- } \\
\text { tica inicial, en refugios } \\
\text { restringidos. }\end{array}$ & Tuina \\
\hline & Paleoindio & & $?$ & & $?$ \\
\hline
\end{tabular}

Tabla 2. Secuencia cronológica resumida del Período Arcaico de la Puna Seca y Salada. 


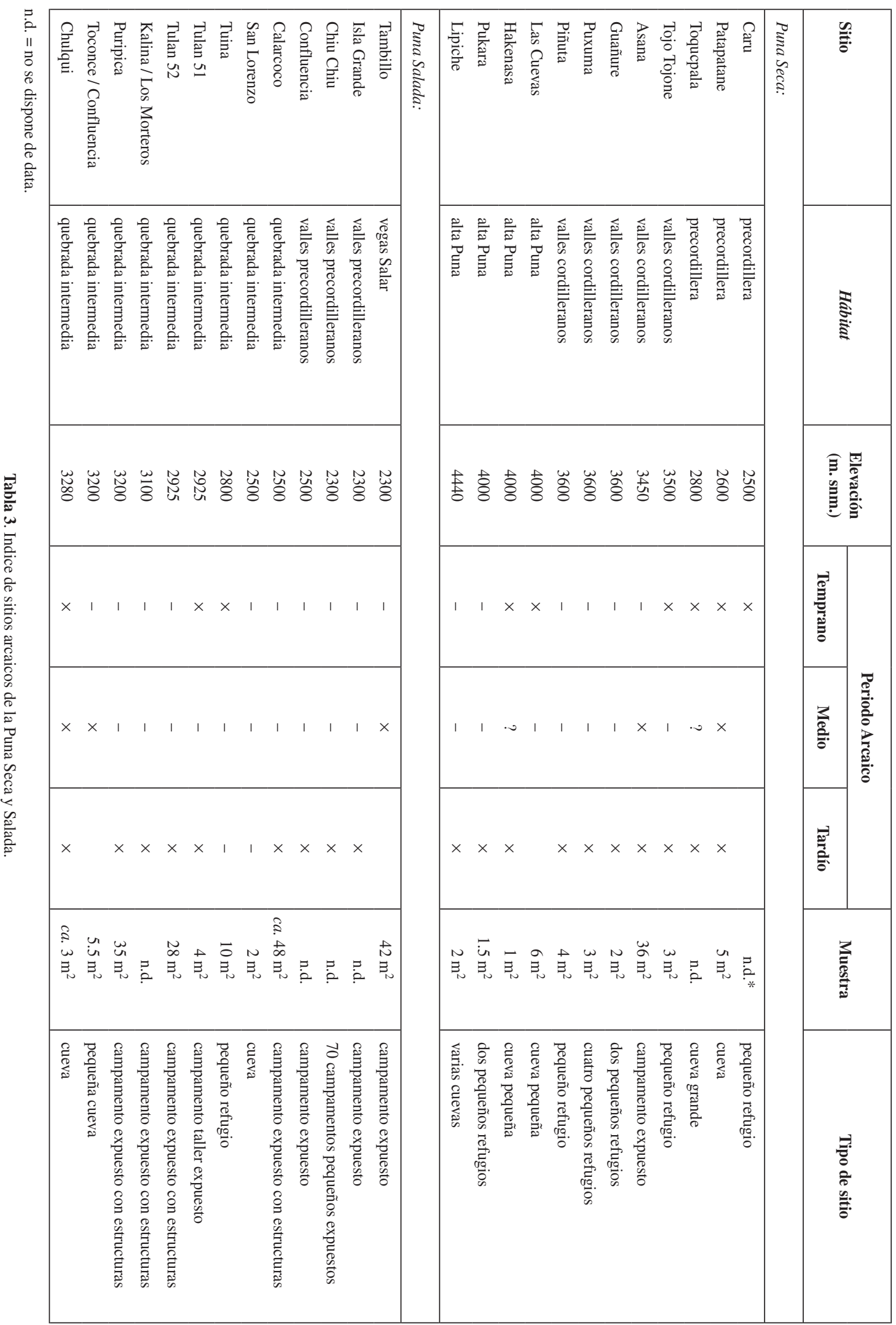


por un micro depósito de cenizas (estrato III) sin ocupación. En tanto que las evidencias del estrato I se han contaminado con depósitos recientes y excrementos de roedores. La base estéril en ambos sectores fue socavada para establecer un espacio resguardado con fines residenciales. Este procedimiento, de acondicionar espacios más deprimidos dentro de cuevas, se observa en Las Cuevas (Santoro y Chacama 1984) e Inca Cueva en el Noroeste Argentino.

Un registro de 71 artefactos líticos, sujetos a clasificación, constituyen la industria lítica. Se caracteriza por el uso predominante de raspadores de dorso alto, raederas, artefactos cortantes, yunques y puntas triangulares presionadas de pequeña factura (Tabla 4 , Figuras 4 y 5).

En la serranía de Tuina se han ubicado otros aleros con ocupaciones similares a la descrita, vinculados a vertientes y actividades de talla lítica en un taller ubicado justo abajo del sitio estudiado. Este sitio repite el mismo tipo de materias primas y artefactos detectados en Tuina 1, en términos de preformas y desechos de talla. De esta manera se pueden reconstruir los circuitos locales entre los aleros altos, vertientes y campamentos al aire libre, dedicados a la talla lítica. El acceso a las quebradas más altas del pie de la Puna y más transitoriamente a la alta Puna fue parte de los circuitos iniciales de mayor alcance territorial (Núñez 1984 Ms).

San Lorenzo, cueva ubicada en uno de los cañones secos que descienden desde la alta Puna hacia el oasis de Toconao, presenta tres fechas tempranas, una de $10400 \mathrm{AP}$, y otra de $9960 \mathrm{AP}$, obtenidas por el primer autor (1983a: 59). Una tercera fecha de 10280 AP, corresponde a una perforación hecha por Spahni, sin contexto publicado (Núñez 1983a; Tabla 8). De nuevo se advierte una ocupación alejada de los territorios altos, orientada a la captura de camélidos, roedores y actividades de recolección,

\begin{tabular}{|c|c|c|c|}
\hline \multirow{2}{*}{ Rasgos } & \multicolumn{3}{|c|}{ Sitios } \\
\hline & Tuina & San Lorenzo & Chulqui \\
\hline $\begin{array}{l}\text { PUNTAS } \\
\text { triangular, base redondeada }\end{array}$ & $x$ & - & - \\
\hline $\begin{array}{l}\text { RASPADORES } \\
\text { dorso alto } \\
\text { dorso bajo } \\
\text { raedera en lasca fina } \\
\text { raedera discoidal } \\
\text { raedera con un lado cóncavo }\end{array}$ & $\begin{array}{l}x \\
\times \\
\times \\
\times \\
-\end{array}$ & $\begin{array}{l}\times \\
- \\
- \\
- \\
\times\end{array}$ & $\begin{array}{l}\times \\
- \\
- \\
- \\
-\end{array}$ \\
\hline $\begin{array}{l}\text { LASCAS } \\
\text { hojas } \\
\text { no modificados c/uso } \\
\text { triangulares retocadas }\end{array}$ & $\begin{array}{l}\times \\
\times \\
-\end{array}$ & $\begin{array}{l}- \\
- \\
\times\end{array}$ & $\begin{array}{l}- \\
- \\
\times\end{array}$ \\
\hline $\begin{array}{l}\text { OTROS } \\
\text { yunques } \\
\text { pomez con estriaciones } \\
\text { huesos de camélidos } \\
\text { lana de camélidos } \\
\text { Lagidium chinchilla } \\
\text { Lagidium viscacia } \\
\text { fragmentos de palos cavadores } \\
\text { bulbos y tubérculos silvestres } \\
\text { aves } \\
\text { Phyllotis }\end{array}$ & $\begin{array}{l}\times \\
- \\
\times \\
- \\
\times \\
- \\
- \\
- \\
- \\
-\end{array}$ & $\begin{array}{c}- \\
\times \\
\times \\
\times \\
\times \\
- \\
\times \\
\times \\
\times \\
\times\end{array}$ & $\begin{array}{l}- \\
- \\
\times \\
- \\
- \\
\times \\
- \\
\times \\
- \\
-\end{array}$ \\
\hline
\end{tabular}

Tabla 4. Artefactos diagnósticos e indicadores culturales de la Puna Salada, Período Arcaico Temprano, Fase Tuina. 


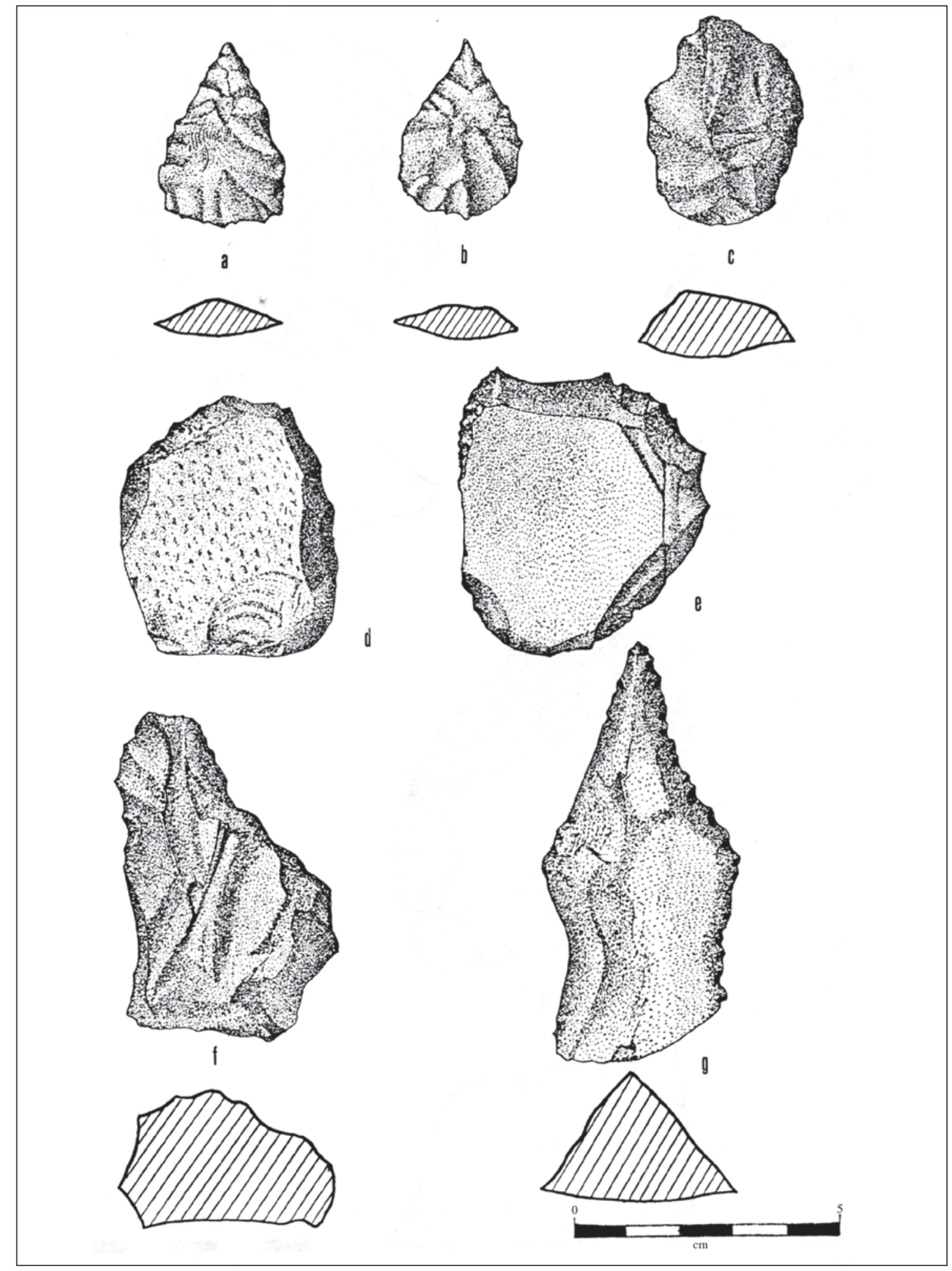

Figura 4. Artefactos indicadores del sitio Tuina (Fase Tuina), Período Arcaico Temprano, de la Puna Salada: a) hoja triangular bifacial de obsidiana (S3W1-E IV); b) hoja triangular bifacial de base redondeada (N1W4-E II); c) raspador elipsoide (C1-E Ia); d) raspador en bordo curvo (S2E1-E IV); e) raspador en un lado curvo (C1-E IV); f-g) raspadores convergentes (N2W2-E IV)-(N7W4-IV). 


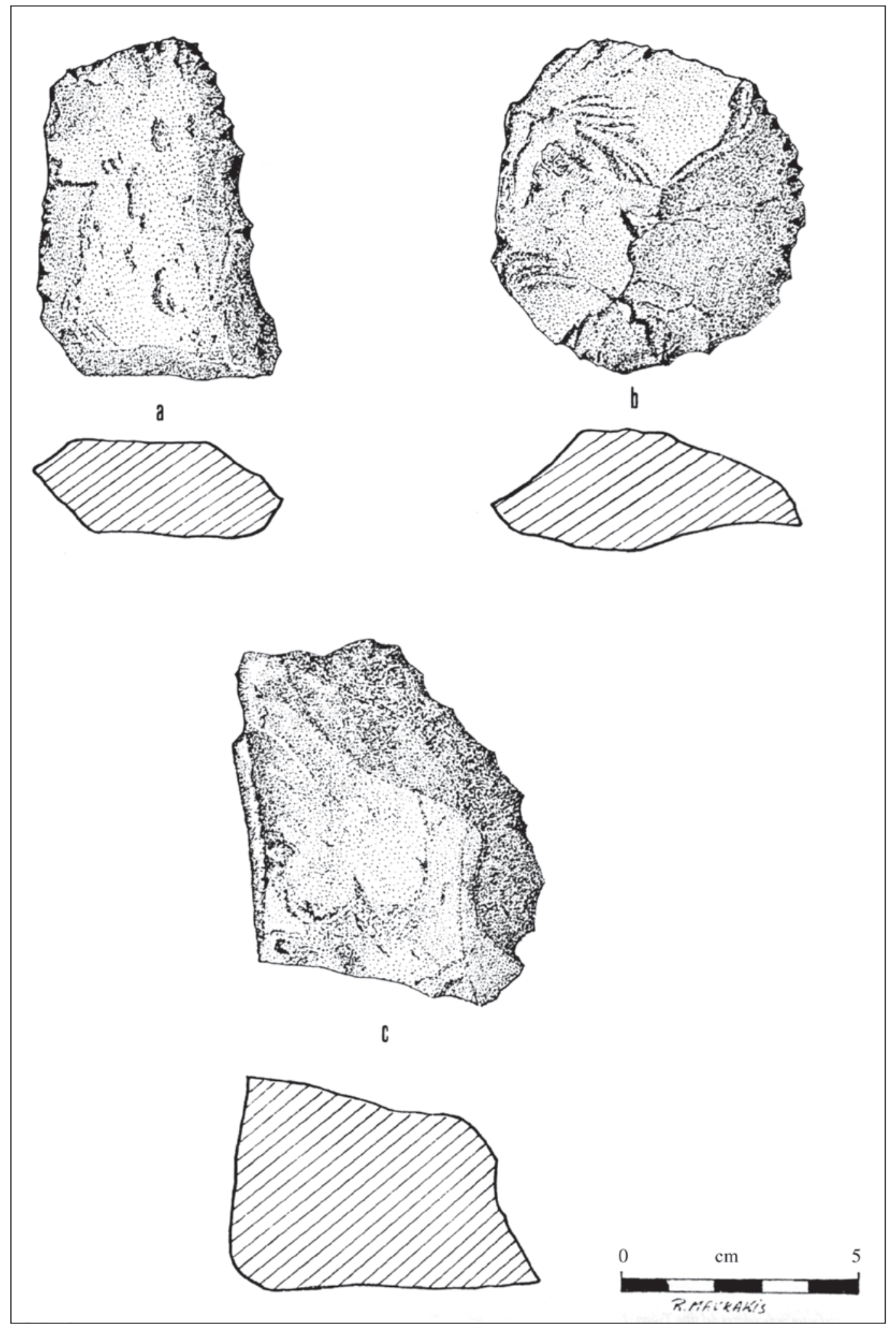

Figura 5. Artefactos indicadores del sitio Tuina (Fase Tuina), Período Arcaico Temprano, de la Puna Salada: a) raspador unilaterial recto (N2W2-E IV); b) raspador discoidal (C1-E Ia); c) raspador tabuliforme de dorso alto en bordo curvo (C1-E IV). 
en un territorio de elevación moderada $(2500 \mathrm{~m})$ y bajo condiciones ambientales similares a las de Tuina. Se detectaron nueve estratos en un depósito de $120 \mathrm{~cm}$ de profundidad y un área de ocupación de $25-30 \mathrm{~m}^{2}$. Los estratos I, II y III corresponden a ocupaciones tardías datadas desde 1355 DC (estrato III). Los estratos IV al IX dan lugar a los episodios tempranos, cuyos artefactos e indicadores culturales se presentan en la Tabla 4. Se puede demostrar que se implantó un régimen de subsistencia apropiado al medio de quebrada y relieve de alturas moderadas, con recursos más adecuados para hábitats de roedores que de camélidos (Núñez 1984 Ms).

El abrigo Chulqui, ubicado aguas abajo del pueblo de Toconce $(3280 \mathrm{~m})$, presenta niveles precerámicos (estratos V y VIa) datados en 9590 AP. Una segunda ocupación en los estratos superiores, sector B, determinó 2130 AP (Sinclaire 1985: 75) (Tabla 8).

El momento de ocupación temprana se vincula con residuos de caza: Lama guanicoe, Lagidium viscacia y recolección de vegetales locales, corno raíces alimenticias con bulbos que aún se recolectan en el perfil de Toconce (Sinclaire 1985). El material lítico reúne a 80 especímenes entre artefactos, desechos, tallados en basalto local, de formas burdas para funciones de corte, raspado y raído (ver Tabla 4).

Estos componentes aunque escasos (excavación en proceso) se comparan coherentemente con los artefactos de Tuina 1, coincidiendo, además, el tipo de fauna cazada y la recolección de raíces detectado en Tuina y San Lorenzo.

Considerando que la fecha de Chulqui es más tardía en relación a los sitios mencionados y que el sitio se ubica en un régimen de mayor altitud, se acepta, siguiendo a Sinclaire (1985) que se trata de episodios tardíos del "patrón Tuina" (Núñez 1984 Ms).

Tuina, San Lorenzo y Chulqui representarían tempranas ocupaciones bajo un patrón de moderada movilidad o trashumancia inicial, circunscrito a la vertiente occidental de la Puna atacameña, incluyendo desde la cuenca media del Loa, oasis y quebradas del Salar de Atacama hasta el valle alto andino del Loa.

Las evidencias aisladas de Tojo Tojone se postularon como un ejemplo de la continuación del modelo de alta movilidad esta vez en la Puna de Arica (Núñez 1983a: 60). Esta interpretación todavía podría mantenerse en pie si Tojo Tojone se continuara analizando en forma aislada en relación a la costa inmediata y, de esta manera, la hipótesis de alta movilidad en avanzadas edades del Holoceno Temprano tendería a reforzarse.

Si se integran las evidencias del territorio alto andino peruano-chileno, con sitios como Las Cuevas, Hakenasa, Toquepala y Caru, se podría sostener, como alternativa, la hipótesis de que a partir de ca. 9500 AP, en la Puna Seca se organizaron circuitos más regularizados de asentamientos que incluyeron distintos enclaves dentro de la Puna, entre los que se incluye Tojo Tojone.

En efecto, al final de la Fase Tuina, en el Período Arcaico Temprano, los patrones de moderada movilidad semitrashumante tienden a desaparecer para dar paso a patrones de definitiva menor movilidad y de carácter menos estacional, lo que marcaría el inicio de la segunda fase del Arcaico Temprano para la cual se ha propuesto el nombre de Patapatane, a base de ocupaciones constatadas al norte de la Puna Salada (Santoro 1986).

\section{Puna Seca. Fase Patapatane ca. 9500-8000 AP}

Esta fase está documentada por los sitios Las Cuevas, Hakenasa, Toquepala, Caru, Patapatane y Tojo Tojone. Las Cuevas y Hakenasa son campamentos localizados en la alta Puna representando una diferencia sustancial respecto de la Fase Tuina en la Puna Salada (ver Tabla 3). Los otros sitios de esta fase se sitúan en los pisos precordilleranos y valles cordilleranos.

Las dataciones radiocarbónicas de la Fase Patapatane se polarizan entre 9500 y 8000 AP sin dataciones intermedias (ver Tabla 8). Las evidencias tempranas de esta fase se representan en los niveles iniciales de los estratos de Toquepala (Ravinés 1967, 1972), Tojo Tojone (Alvarez 1980; Dauelsberg 1983) y Las Cuevas (Santoro y Chacama 1984). Los principales indicadores culturales se resumen en la Tabla 5.

El sitio Tojo Tojone ( $c a .9500 \mathrm{AP}$ ) se caracteriza por sus puntas lanceoladas espesas, que han sido comparadas con formas parecidas datadas 3000 años más tarde en la costa de Camarones; para sugerir un flujo trashumántico desde la sierra hacia los valles y costa específica. También se sugirieron 


\begin{tabular}{|c|c|c|c|c|c|c|}
\hline \multirow{2}{*}{ Rasgos } & \multicolumn{6}{|c|}{ Sitios } \\
\hline & Toquepala & Tojo Tojone & Las Cuevas & Patapatane & Hakenasa & Caru \\
\hline \multicolumn{7}{|l|}{ PUNTAS } \\
\hline \multicolumn{7}{|l|}{ Puntas lanceoladas: } \\
\hline doble punta & $x$ & $x$ & - & - & - & - \\
\hline base redondeada & $x$ & $x$ & - & - & - & - \\
\hline aserrada c/aletas laterales & $x$ & $x$ & - & 3 & - & - \\
\hline \multicolumn{7}{|l|}{ Puntas triangulares: } \\
\hline pedúnculo paralelo & $x$ & $x$ & 2 & - & - & - \\
\hline pedúnculo convergente & - & - & 1 & - & 2 & - \\
\hline pedúnculo largo & $x$ & - & - & - & - & - \\
\hline isósceles & - & - & 1 & & - & - \\
\hline Romboidales: & & & - & - & - & - \\
\hline con pedúnculo ancho & $x$ & - & - & - & - & - \\
\hline con aletas laterales & - & - & - & 3 & - & $x$ \\
\hline \multicolumn{7}{|l|}{ CUCHILLOS (retocados) } \\
\hline lanceolado ancho & - & - & - & 1 & - & - \\
\hline lanceolado estrecho de sección espesa & - & $x$ & - & 1 & - & - \\
\hline lanceolado base redondeada & - & - & 1 & - & 2 & - \\
\hline \multicolumn{7}{|l|}{ lanceolado monofacial } \\
\hline base recta & - & - & 1 & - & - & - \\
\hline hoja triangular & - & - & 2 & - & - & - \\
\hline hoja ovoidal & - & - & 2 & - & - & - \\
\hline \multicolumn{7}{|l|}{ CUCHILLOS (lascas con uso) } \\
\hline lascas de hoja semicircular & - & - & - & 1 & 1 & - \\
\hline lascas no modificadas con uso & - & - & $x$ & - & - & - \\
\hline \multirow{3}{*}{$\begin{array}{l}\text { RASPADORES } \\
\text { dorso alto } \\
\text { semicirculares dorso bajo }\end{array}$} & & & - & - & - & - \\
\hline & - & - & - & - & 1 & - \\
\hline & - & - & 2 & - & 1 & - \\
\hline \multicolumn{7}{|l|}{ OTROS } \\
\hline fragmentos de Choromytilus con uso & - & - & - & $x$ & - & $\times$ \\
\hline retocadores de hueso & - & - & - & 1 & - & $x$ \\
\hline pigmento rojo & $x$ & - & $x$ & $x$ & - & $x$ \\
\hline
\end{tabular}

Tabla 5. Artefactos diagnósticos e indicadores culturales de la Puna Seca, Período Arcaico Temprano, Fase Patapatane.

movimientos entre la sierra y la alta Puna (Dauelsberg 1983: 14-17).

Debe agregarse como nuevo elemento diagnóstico en Tojo Tojone la presencia de puntas triangulares con pedúnculo, similares a las de Las Cuevas (Figura 6: 1 y 2). Estas fueron encontradas en una ampliación de la excavación, cuyos materiales se encuentran en proceso de estudio. Este modelo de punta triangular se recuperó en el estrato más profundo, donde no se hallaron las puntas lanceoladas espesas reportadas anteriormente (Dauelsberg 1983).

En niveles más tardíos, aparecen hojas lanceoladas más delgadas y anchas, similares a las encontradas en los estratos del Arcaico Tardío en el sitio Hakenasa (Figura 11: 48 y 49).

En Las Cuevas el depósito temprano de ocupación está sellado por espesos bloques de roca liparítica 
caídos desde el techo de la cueva (Santoro y Chacama 1982, 1984). El depósito de ocupación temprano (Las Cuevas 1) ocupaba 20-25 cm de espesor y fue dividido en tres niveles arbitrarios. El nivel superior presenta la mayor concentración de restos culturales y una datación de 9540 años AP. Los niveles medio e inferior representan ocupaciones más tempranas con escasos restos culturales.

Se excavaron $6 \mathrm{~m}^{2}$ con un inventario de 2227 artefactos clasificados, de los cuales 1771 (79.5\%) pertenecen a los niveles de la Fase Patapatane.

Considerando los niveles en conjunto se destaca una alta proporción y diversidad de artefactos líticos. Huesos y otros restos orgánicos son escasos. Se distinguieron 16 agrupaciones de instrumentos clasificados en puntas, raspadores y cuchillos. Como rasgos miscelánicos se registraron piedras pintadas sin diseños definidos, pigmentos de color rojo y un diente de tiburón, evidenciando cierto tipo de contacto con la costa (ver Tabla 5 y Figura 6).

El sitio Las Cuevas representaría un típico campamento temporal en el borde del bofedal orientado a la explotación eficiente de sus recursos concentrados. Pudo ser una banda pequeña de cazadores, si se considera el reducido espacio interior de la cueva y la baja densidad de los restos de ocupación. La alta incidencia de lascas y desechos de percusión y presión demostraría que la gente se instalaba, en el interior de la cueva, a preparar sus instrumentos de caza y faenamiento.

Considerando el tamaño de epífisis y diáfisis se hizo una segregación tentativa de los huesos en animales pequeños (roedores y aves) y animales mayores (camélidos y venados), lo que demostraría preliminarmente, un nivel de caza diversificada que se corresponde con la variedad de instrumentos empleados. Señalaría, también, un manejo especializado e integral de la ecozona. Tomando en cuenta su posición en un nivel bajo dentro de la Puna (ca. $4000 \mathrm{~m}$ ), se sugiere que era un campamento reservado para el invierno (mayo-septiembre), cuando las condiciones son más inhóspitas en cualquier otro nivel dentro o fuera de este piso.

El conjunto tardío de la Fase Patapatane del Período Arcaico Temprano, compromete los estratos inferiores de los sitios Patapatane, Hakenasa y Caru. Para este último, Ravinés (1967: 46) obtuvo una fecha de 8190 AP, cercana a la fecha en el sitio Patapatane de 8160 AP y a la segunda muestra de Las Cuevas, de 8270 AP (ver Tabla 8).

El depósito excavado en Patapatane presenta una profundidad promedio de $123 \mathrm{~cm}$ y fue subdividido en 12 niveles. Los componentes correspondientes a esta época tardía de la Fase Patapatane provienen de los niveles más profundos J, K, L y M (Patapatane 1) y cubren un espesor de $5-35 \mathrm{~cm}$. Se inventariaron 284 artefactos, para esta fase que representan el $11.73 \%$ en relación a la muestra total del sitio. La mayor cantidad son líticos: lascas, microlascas, desechos e instrumentos (uno de hueso). Destacan como rasgos miscelánicos fragmentos de Choromytilus, uno con señal de uso, pigmento rojo y un fragmento de arenisca rebajada (ver Tabla 5 y Figura 7).

Los restos de huesos, correspondientes a esta época, señalan importante actividad de faenamiento de animales llevados por presas desde los sitios de matanza. También sugiere que las condiciones ecológicas del piso precordillerano, donde se ubica el sitio, debieron ser menos áridas que las actuales, para ofrecer una alternativa a los cazadores en la búsqueda de recursos complementarios. Análisis preliminares de los restos óseos sugieren una alta proporción de camélidos entre los restos identificados (Denis 1987 Ms). La elaboración de artefactos fue una actividad secundaria, a juzgar por los escasos desechos de percusión. Ambos factores señalarían que Patapatane fue, principalmente, una estación de caza de baja densidad ocupacional. Estos datos permiten sugerir que Patapatane I sería un campamento transitorio correspondiente a cazadores de camélidos, roedores y aves. La presencia de camélidos y roedores sugieren que el área pudo estar disponible en cualquier época del año, pero seguramente fue más propicia en verano y parte del otoño (octubre-abril), cuando los pastos han crecido con las lluvias y ocurren las pariciones de los camélidos. De esta manera, se complementaban los campamentos-bases de invierno localizados alrededor de los bofedales de la Puna. El último sitio con evidencias estratigráficas para la Fase Patapatane es Hakenasa donde se ha excavado un pozo de sondeo de $1 \mathrm{~m}^{2}$ y $2.23 \mathrm{~m}$ de profundidad.

Los episodios correspondientes a la Fase Patapatane del Período Arcaico Temprano comprometen los niveles 

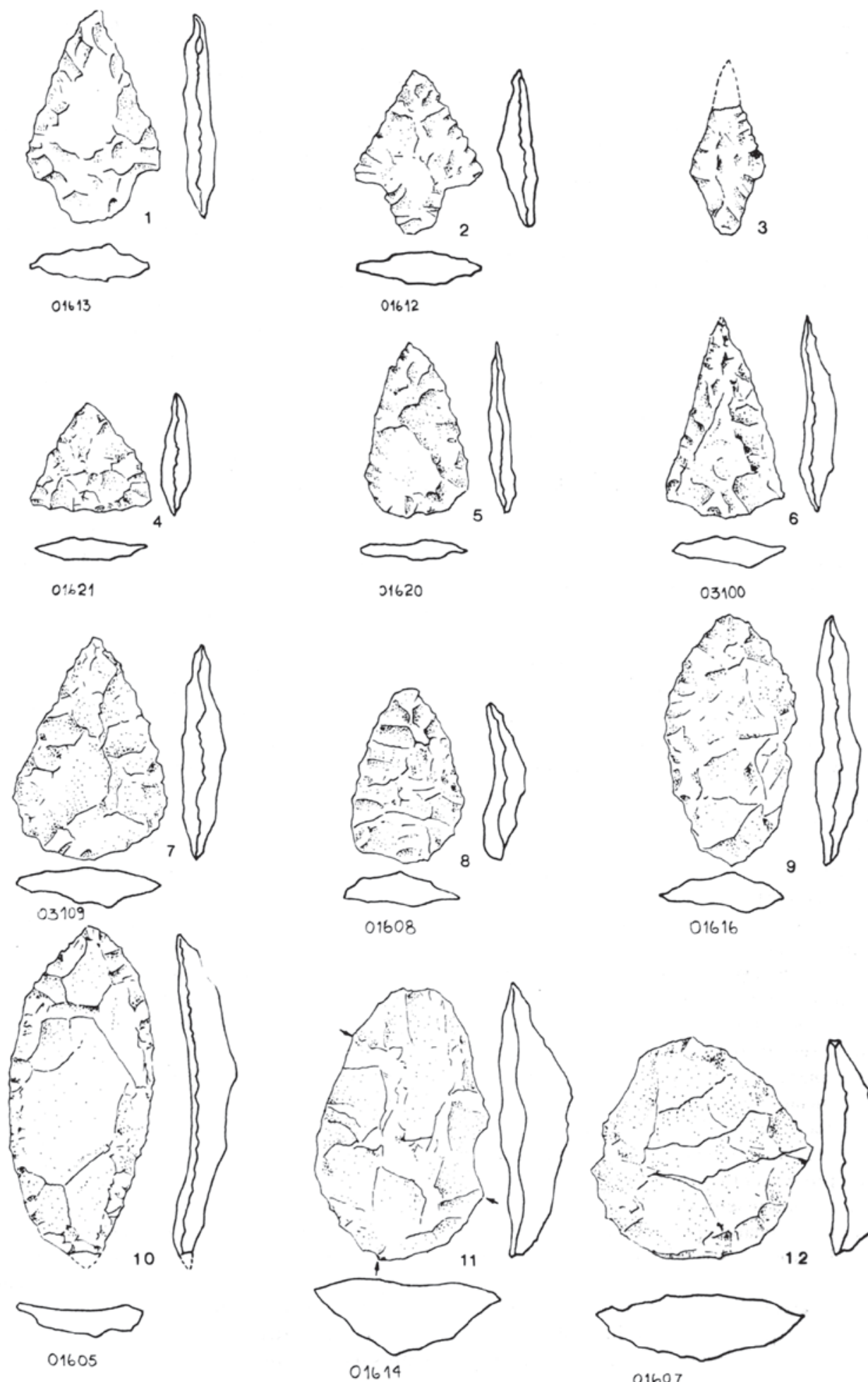

LAS CUEVAS

Figura 6. Artefactos indicadores del sitio Las Cuevas. Fase Patapatane del Período Arcaico Temprano de la Punta Seca. 


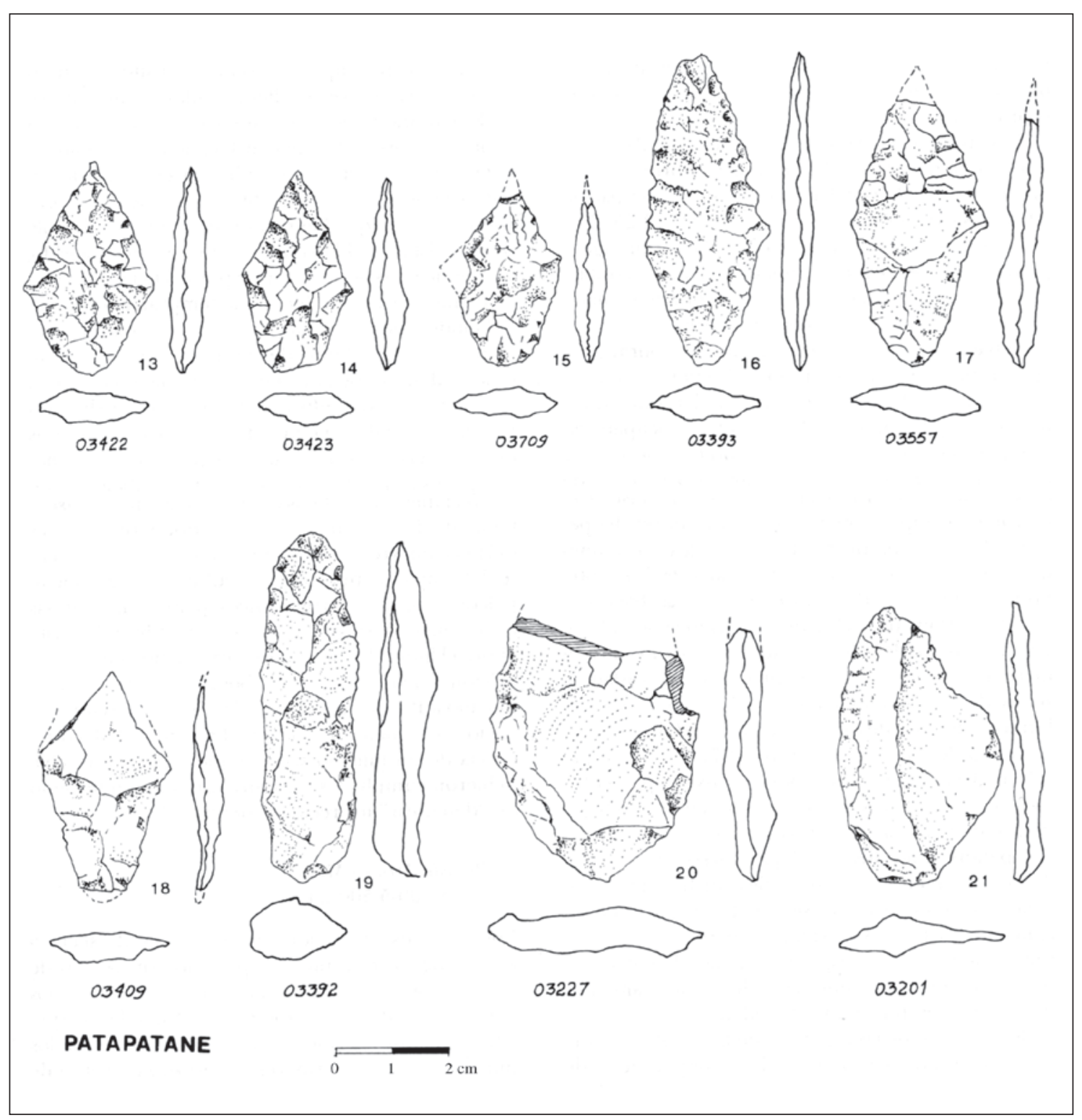

Figura 7. Artefactos indicadores del sitio Patapatane. Fase Patapatane. Componente Patapatane I del Período Arcaico Temprano de la Puna Seca. El artefacto $n^{\circ} 16$ corresponde al Período Arcaico Medio del Componente Patapatane II.

21 al 24, con baja densidad de ocupación (Hakenasa I) (ver Tabla 5 y Figura 8: 22-25, 29 y 30). Los pocos restos de hueso señalarían un ligero predominio de caza de animales mayores (posiblemente vicuña, guanaco o venado), complementado con animales menores (aves y roedores).

Hakenasa I fue un campamento temporal para aprovechar el refugio cerrado de la cueva y los estables recursos ofrecidos por los bofedales de Anco-pujo y Cosapilla (Santoro Ms). Pudo ser ocupado en cualquier época del año incluyendo el invierno por las mismas razones sugeridas para la ocupación de Las Cuevas I.

El uso estacional de las praderas y pendiente occidental andina dado actualmente por los pastores de Cariquima (Van Kessel 1980) podría ilustrar el patrón de comportamiento de los cazadores del Período Arcaico Temprano. En efecto, los cariquimeños 


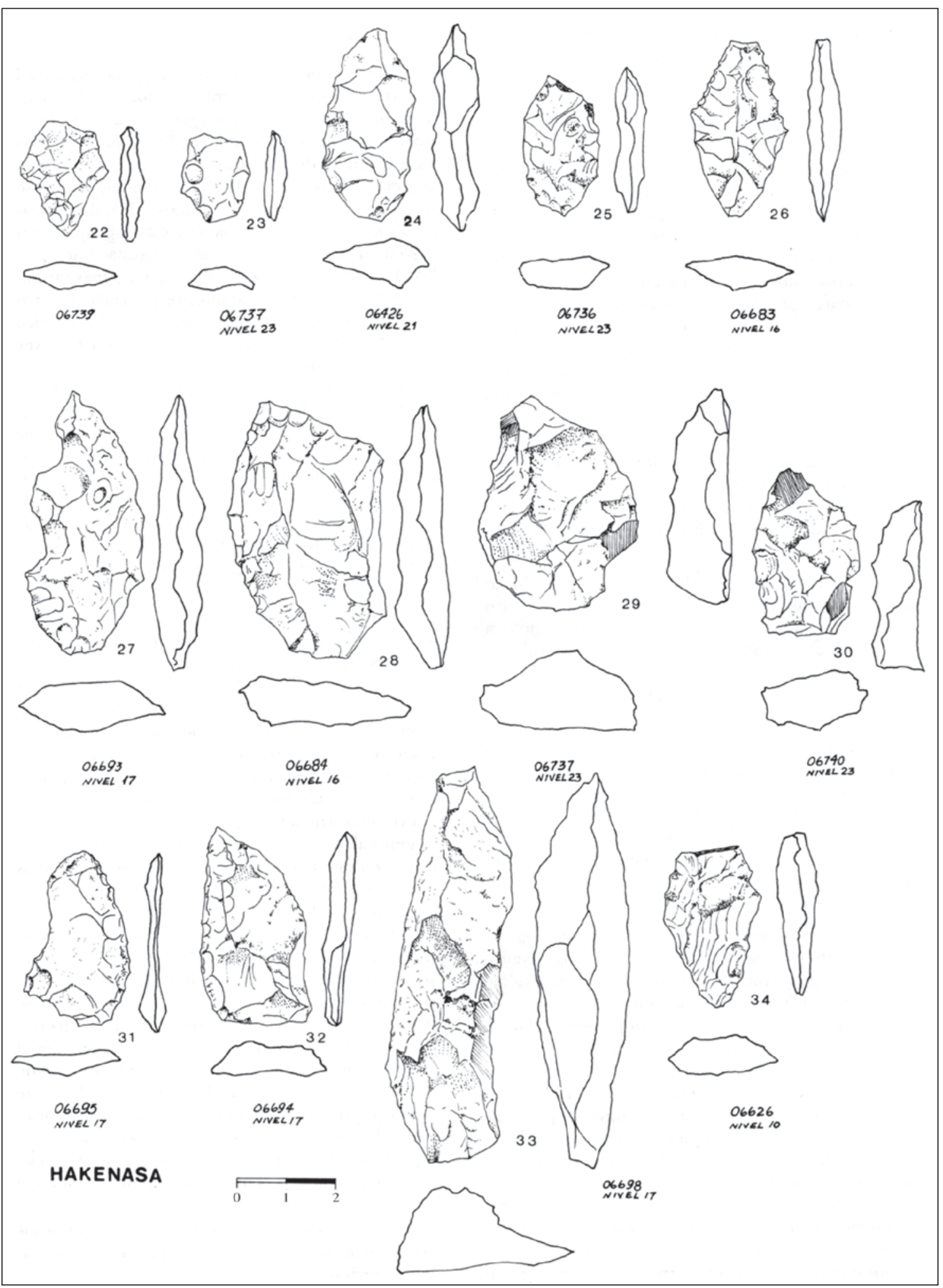

Figura 8. Artefactos indicadores del sitio Hakenasa. Hakenasa I (Período Arcaico Temprano): 22 a 25, 29, 30. Hakenasa II (Período Arcaico Medio): 26 a 28, 31 a 33. Hakenasa III (Período Arcaico Tardío): 34. 
actuales reservan las praderas altas (sobre $4000 \mathrm{~m}$ ) para el verano (diciembre-marzo) y las bajas (ca. 3700-4000 m) para el invierno (junio-septiembre). Un patrón similar de uso del bofedal durante el invierno (estación seca) combinado con el traslado a zonas de pastos más bajos en el verano (estación húmeda) ha sido descrito en la localidad de Espinar, zona alta de Arequipa (Orlove 1977: 91). Este patrón podría estar representado por los campamentos de Las Cuevas y Hakenasa, ubicados en niveles bajos dentro de la Puna. Por su parte, Caru, Toquepala y Patapatane ubicados en el piso precordillerano y Tojo Tojone en el piso de valles cordilleranos, podría corresponder a otro segmento del patrón estacional de Cariquima y Espinar, que representan distintas combinaciones espaciales, teniendo como elemento común la concentración de los campamentos de invierno en torno a los bofedales.

En el marco de las hipótesis, en la Fase Patapatane se destaca la notable aparición de varios paraderos de cazadores tempranos en una zona restringida de la Puna Seca, lo que señalaría que las condiciones climáticas fueron favorables para animales y cazadores andinos que adoptaron como propio esta auspiciosa región. Sin embargo, los datos arqueológicos disponibles para este período no permiten aclarar de qué manera los enclaves de la alta Puna -bofedales- se combinaron durante el invierno con los recursos de caza disponibles en verano en los pisos precordillera y valles cordilleranos. $\mathrm{Si}$ nuestras deducciones ecológicas y etnográficas son correctas es posible que un patrón estacional de caza ocurrió en las tierras altas de la Puna Seca, donde los campamentos de invierno localizados en la alta Puna pudieron alternarse con campamentos más transitorios en los pisos más bajos (precordillera y valles cordilleranos).

El panorama es más complejo aún si se intenta explicar la presencia de conchas de Choromytilus en Patapatane y el diente de tiburón en Las Cuevas. Patapatane se encuentra a $60 \mathrm{~km}$ en línea recta de la costa, mientras que Las Cuevas se encuentra al doble de esta distancia. El primer autor (1984) ha sugerido, siguiendo su experiencia de la Puna Salada, que estos elementos corresponden a una temprana expresión del modelo de movilidad trashumántica inicial sugerido para la Fase Tuina de la Puna atacameña. Pero, esta evidencia costera tiene la misma fuerza para sostener que los cazadores habrían alcanzado hasta el litoral o que habrían obtenido estas conchas y quizás otros materiales a través de trueque, o sistemas más complejos de interacción, como intercambios territoriales entre grupos distintos que tenían residencias relativamente permanentes en las tierras altas o bajas, tal como ocurre entre los ona. Evidentemente, definiciones más detalladas de los patrones de asentamiento de las sociedades de cazadores recolectores del Período Arcaico Temprano requieren claramente del acopio de nuevos datos culturales, geológicos, paleoecológicos y cronológicos para esclarecer las conexiones entre las tierras altas y el litoral. Hasta ahora el litoral fue ocupado inicialmente, tanto en la sección árida como en las bocas de los ríos $c a$. X milenio AP, mientras que en las tierras altas las ocupaciones comienzan $c a$. en el undécimo milenio AP. La diferencia de un milenio sugiere que algún rol posible debieron cumplir los cazadores andinos en término de "descubrir" los recursos del litoral.

\section{c) Período Arcaico Medio (ca. 8000-5500 AP?)}

Los registros muestran una tendencia al "silencio arqueológico" durante este período por desvíos de exploración u otras causas involucradas con cambios ambientales. Por esta razón no se definen fases específicas. Todos los sitios tempranos reseñados muestran en este período un marcado descenso de actividades e incluso largos abandonos, con cortos y esporádicos retornos. Este "abandono" de los ambientes de la alta Puna corresponde al Optimum climaticum, un estadio de eventual clima seco y cálido de acuerdo al esquema de Núñez y colaboradores (1983). Mientras tanto Ybert y Miranda (1984) documentan un clima frío y seco entre 6000 y 7500 AP en la zona de Sajama. Este episodio pudo afectar la disponibilidad de recursos de la Puna presionando a los cazadores a buscar fuentes complementarias con recursos más estables como la costa, donde, coincidentemente, se iniciaron ocupaciones más intensivas y permanentes (p.e., Quiani, Camarones 14, Camarones Punta Norte, Quiani 9, entre otro; Bird 1943; Willey 1971: 199; Niemeyer y Schiappacasse 1977; Dauelsberg 1982; Muñoz y Chacama 1982; Schiappacasse y Niemeyer 1984).

\section{Puna Seca}

Las escasas evidencias del Arcaico Medio recuperadas en Patapatane corresponden a los niveles $\mathrm{H}$ e I (Patapatane II) sin dataciones radiocarbónicas 
por la falta de carbones concentrados en situación estratigráfica. Estos estratos se asignaron al Período Arcaico Medio debido a su ubicación relativa entre los niveles correspondientes a los niveles arcaicos tempranos y tardíos. Los artefactos diagnósticos encontrados en los niveles $\mathrm{H}$ e I incluyen puntas lanceoladas con pequeñas aletas cerca de la base, continuadas del Arcaico Temprano (Figura 7: 16) y un punzón de hueso menos elaborado que los del período anterior. Los restos óseos señalan una caza diversificada, con mayor incidencia de camélidos sobre roedores, entre los que se identifican Lagidium viscacia y Galea musteloides (cuy de la Puna). También se identificó restos de un cérvido adulto (Denis $1987 \mathrm{Ms}$ ).

En Hakenasa los niveles 15 al 19 asignados al Período Arcaico Medio (Hakenasa II) se ubican igualmente entre los estratos del Período Arcaico Temprano y Tardío. Tampoco ha sido acotado con dataciones absolutas. Entre los escasos restos de ocupación se cuentan puntas, cuchillos y preformas (Figura 8: 26-28 y $31-33)$.

En ambos sitios las formas de los instrumentos derivan de las tradiciones tempranas, lo que podría indicar que se trataba de grupos relictuales quienes, esporádicamente, retornaban a los pisos de la Puna; sin que se pueda establecer con claridad, ahora, si sus campamentos-base estuvieron en la costa, o en algún nicho de la Puna que todavía no hemos localizado.

Esta situación de aparente "silencio arqueológico" en la región podría variar de acuerdo a los novedosos datos recientemente descubiertos por Aldenderfer (1988) en el sitio Asana, en el río Osmore, Moquegua (3450 m). Se trataría de un campamento abierto ubicado en el piso de valles cordilleranos con evidencias de estructuras habitacionales correspondientes al Arcaico Medio (ca. 6000-6500 AP; ver Tabla 8). Los restos de ocupación señalan intensas prácticas de caza de camélidos complementadas con una baja proporción de venados. También se han recuperado semillas no identificadas. De esta manera, el sitio representa la primera evidencia de estructuras habitacionales en las tierras altas (Puna Seca), cuyos componentes en proceso de estudio entregarán una mejor comprensión de los patrones de asentamiento de las sociedades arcaicas.

\section{Puna Salada}

Otros campamentos se han ubicado en las playas del Salar de Atacama (2300 m) y en torno a los oasis piemontanos, vegas y microlagos. Así, la concentración de avifauna andina y roedores locales en las vegas y lagunas del salar estimuló el acceso estacional, surgiendo sitios anteriores a Tulan como Tambillo, donde se registró un cementerio con cráneos dolicoides asociados a morteros. Es probable que estas agrupaciones provenían de quebradas más altas (estaciones cálidas), de lugares como Calarcoco datado más tardíamente hacia 5120 AP, al interior de Toconao, otro transecto que presenta un patrón trashumántico típico (Serracino y Pereyea 1977; Núñez 1980) (ver Tablas 3 y 8).

La ocupación de Tambillo, un campamento expuesto en el borde del Salar de Atacama, se ha fechado recientemente a los 8590 AP (Núñez Ms; ver Tabla 8). Presenta el primer conglomerado habitacional asociado a un reducido cementerio. Son recintos circulares socavados, con morteros cónicos y una típica industria de hojas triangulares, raspadores chatos de uña, perforadores finos de obsidiana y ganchos de hueso para propulsores (Figuras 9 y 10).

Se correspondería con las ocupaciones ancestrales del poblamiento arcaico con morteros de la Puna Salada. Se trata de la primera ocupación que inicia el Período Arcaico Medio. Después se establecen los episodios Confluencia (5380 AP) e Isla Grande (6008 AP) (ver Tablas 3 y 8), donde los cazadores recolectores con similares morteros cónicos y puntas lanceoladas se instalaron en campamentos expuestos, también en cotas sensiblemente bajas, esta vez en torno a las vegas del río Loa Medio. Pero en general, no hay evidencias de un activo poblamiento en este período, a lo largo de las tierras altas (entre los 2500 a $4000 \mathrm{~m}$ ) de la vertiente occidental de la Puna Salada. ¿Qué pudo ocurrir si es cierto que hubo una eventual desocupación sobre los $2500 \mathrm{~m}$ ? Independientemente de una disminución de los recursos forrajeros por pulsaciones de regímenes secos, aún no evaluados con análisis de polen in situ, se deben considerar las alteraciones volcánicas. En efecto, recientes estudios han probado que a lo menos el volcán Socompa, ubicado al sureste de San Pedro de Atacama, provocó una avalancha catastrófica que cubrió un área de 490 km² (actividad magmática). Este colapso fue acompañado por erupciones de flujo piroclástico pumisítico que en 


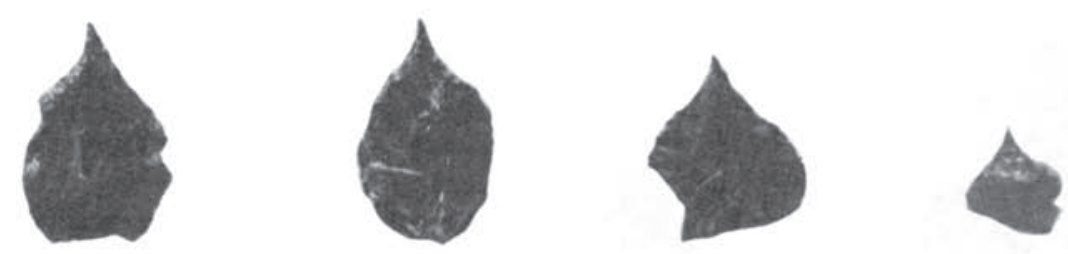

A
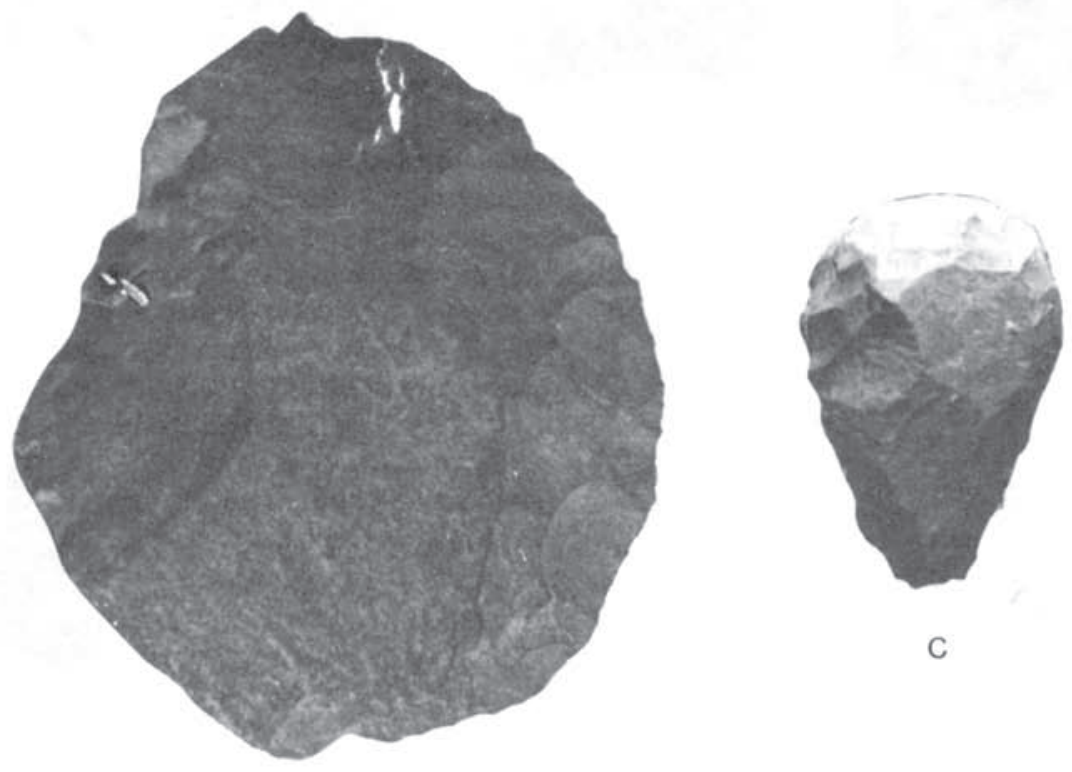

C

B

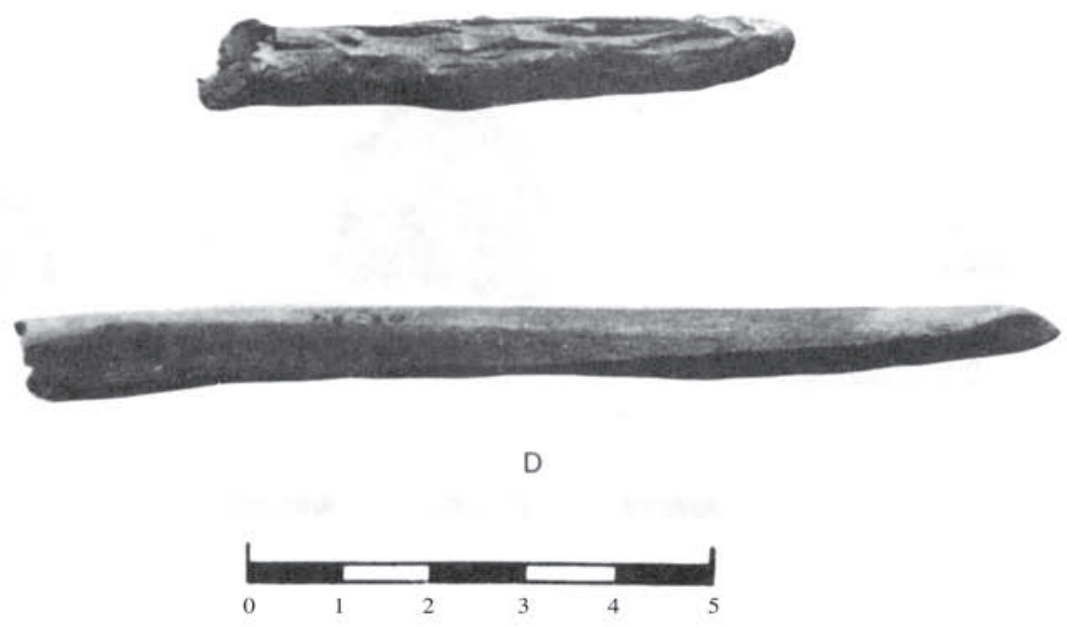

Figura 10. Industria típica del sitio Tambillo 1 (comienzo de ocupación: A) Perforadores de lascas de obsidiana; B) Raspador semidiscoidal; C) Raspador frontal; D) Artefactos óseos con extremo distal agudo o romo. 
conjunto hicieron poco tolerable la ocupación del flanco occidental del área afectada.

Dataciones de maderos carbonizados (depósitos piroclásticos) señalan una edad máxima de la avalancha del orden de $7220 \pm 100$ AP y una mínima de $1860 \pm 60$ AP (Francis et al. 1985). Estos datos hablan a favor de una etapa holocénica cercana a los 7000 AP, en donde toda ocupación humana emplazada en la pendiente occidental de la alta Puna pudo afectarse sensiblemente si estos eventos fueron más generalizados. Esto podría explicar el incremento de la ocupación de los pisos más bajos, incluido el litoral. Si estos episodios ocurrieron también en torno a la Puna Seca, la posibilidad de comprender eventuales descensos, ausencias o abandonos de ocupaciones en las tierras altas durante este período, sería útil para desarrollar otras hipótesis de alternativa y no excluyentes con la tesis de un déficit de recursos.

También en la Puna Seca otros estudios geológicos recientes documentan una gran actividad volcánica de tipo catastrófico ocurrido el final del Pleistoceno ( $c a .13000 \mathrm{AP}$ ) y que continuó durante el Holoceno. Esto incluye, por ejemplo, el colapso y erupción magmática del volcán Parinacota, cuyos materiales habrían provocado la formación del lago Chungará, lagunas de Cotacotani y laguna-bofedal de Parinacota (H. Moreno, com. pers.; Craig 1984). Los mismos estudios han podido determinar que la formación del actual volcán Parinacota habría ocurrido durante el Holoceno en época que no ha sido definida con precisión (H. Moreno, com. pers.). Sin embargo, considerando los datos de la Puna de Atacama, probablemente esta actividad volcánica pudo haber tenido un carácter regional afectando en épocas relativamente sincrónicas a la Puna Salada y Seca.

\section{d) Período Arcaico Tardío (5500?-4000 AP)}

Este período correspondería al clímax de ocupación de los cazadores arcaicos con uso extensivo de una mayor diversidad de enclaves dentro de las ecozonas de la Puna, con patrones de asentamientos particularizados tanto en la Puna Seca como en la Salada.

\section{Puna Seca}

Varios sitios documentan este período: Patapatane (precordillera), Puxuma, Piñuta, Guañure y Tojo Tojone (valles cordilleranos) (Santoro y Chacama
1982, 1984; Dauelsberg 1983) y Hakenasa, Lipiche y Pukara en el piso alta Puna (Santoro Ms). Se propone el nombre de Fase Hakenasa, considerando que este sitio representa en mejor forma al Período Arcaico Tardío.

La explotación más especializada del área queda evidenciada por la amplia utilización de artefactos más diversificados; algunos continúan o recuerdan tradiciones anteriores evolucionadas en diversos sentidos. En términos generales, se observa una reducción del tamaño de los instrumentos, como reflejo de nuevas tecnologías o por la simple adopción de nuevas formas de instrumentos, destinadas a la misma actividad: caza de camélidos, venados, roedores y aves.

Este tradicional énfasis cazador representaría un nivel de caza especializada, acentuado por las condiciones de la Puna Seca, como lo fue la ausencia de plantas de recolección susceptibles de molienda versus el dominio de plantas forrajeras que soportan diversas e importantes presas de caza.

Esta situación no se repite con el mismo acento en la Puna Salada (transecto oasis piemontanos-alta Puna) donde la recolección de frutos de Prosopis, bulbos, gramíneas, raíces silvestres suculentas, énfasis en caza menor, jugaron un significativo rol en la definición del patrón de asentamiento trashumante, circunscrito al perfil occidental de la Puna de Atacama, que incluía la cuenca del Loa, quebradas, oasis y vegas de la cuenca del Salar y la alta Puna, como un territorio con pisos complementarios explotados estacionalmente.

El sitio Hakenasa presenta para el Arcaico Tardío, en la Puna Seca, una fecha de 4380 AP (ver Tabla 8), obtenida en el estrato intermedio del depósito correspondiente a esta época y que representa el clímax de ocupación (Hakenasa III). Se recuperó una gran cantidad de puntas de proyectil, cuchillos, raederas, raspadores, un perforador cilíndrico, un afilador, sobadores de cuero, percutores, una cuenta de collar, pigmentados de color rojo y un canto rodado con señas de uso y dos machacadores (Tabla 6 y Figuras 11, 12, 13).

Se asocian formas triangulares de cuchillos (Figura 13: 79-80) y los primeros ejemplares de puntas triangulares escotadas (Figura 13: 81-83). Estos nuevos tipos triangulares, con o sin escotadura, reemplazan en el período siguiente (Formativo) a las tradicionales 


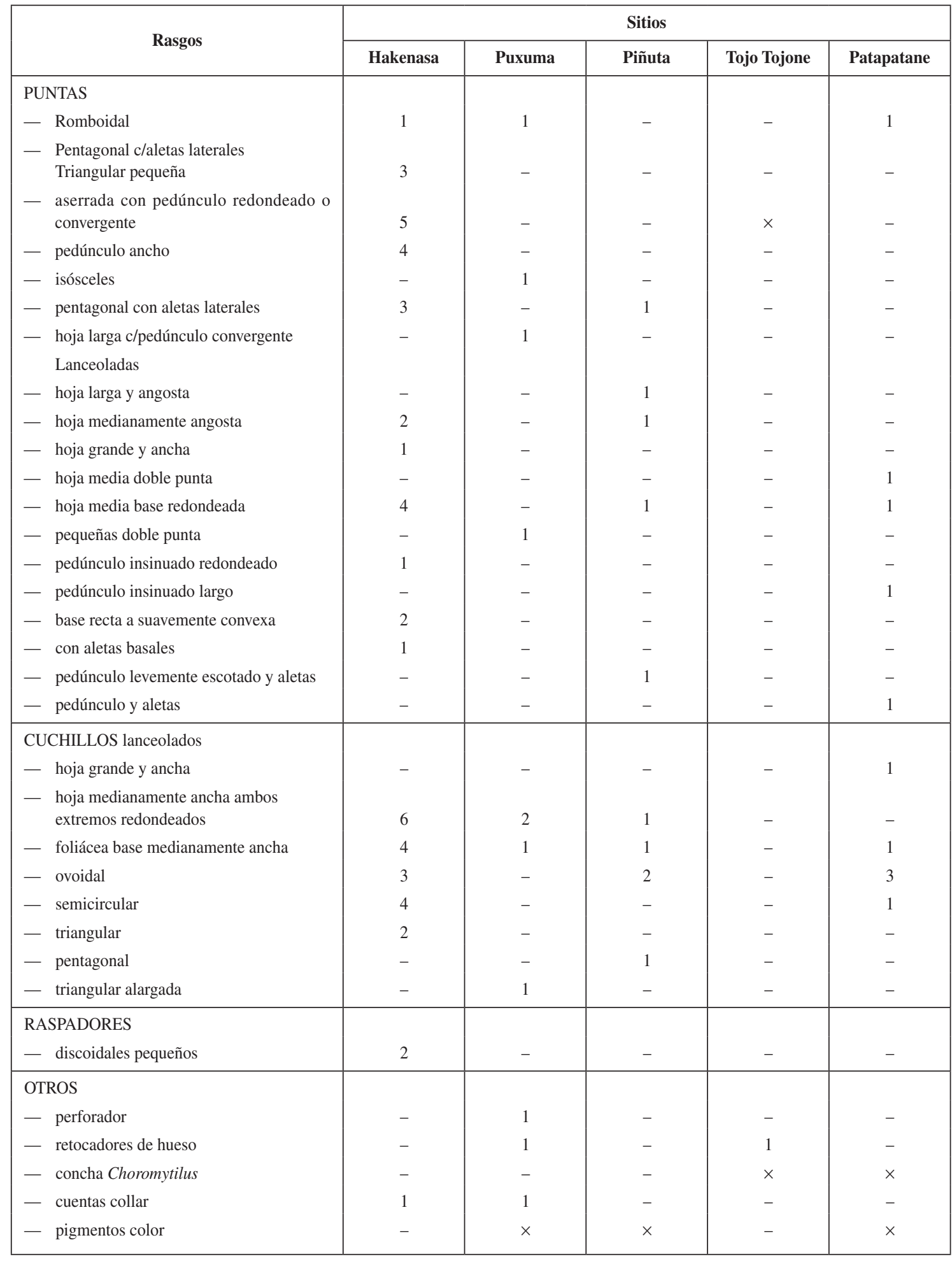

Tabla 6. Artefactos diagnósticos e indicadores culturales de la Puna Seca, Período Arcaico Tardío, Fase Hakenasa. 


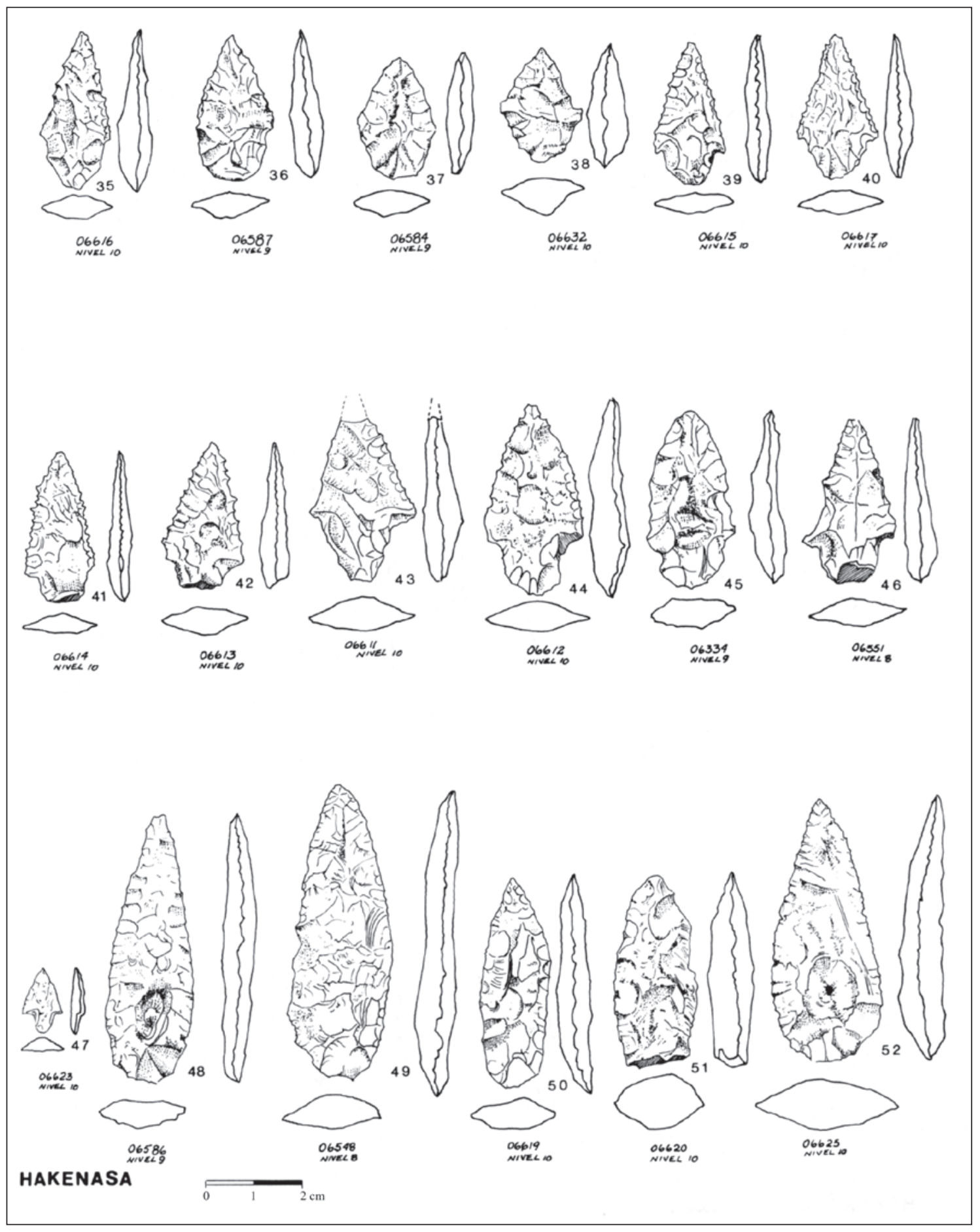

Figura 11. Artefactos indicadores del sitio Hakenasa, Componente Hakenasa III del Período Arcaico Tardío de la Puna Seca. 


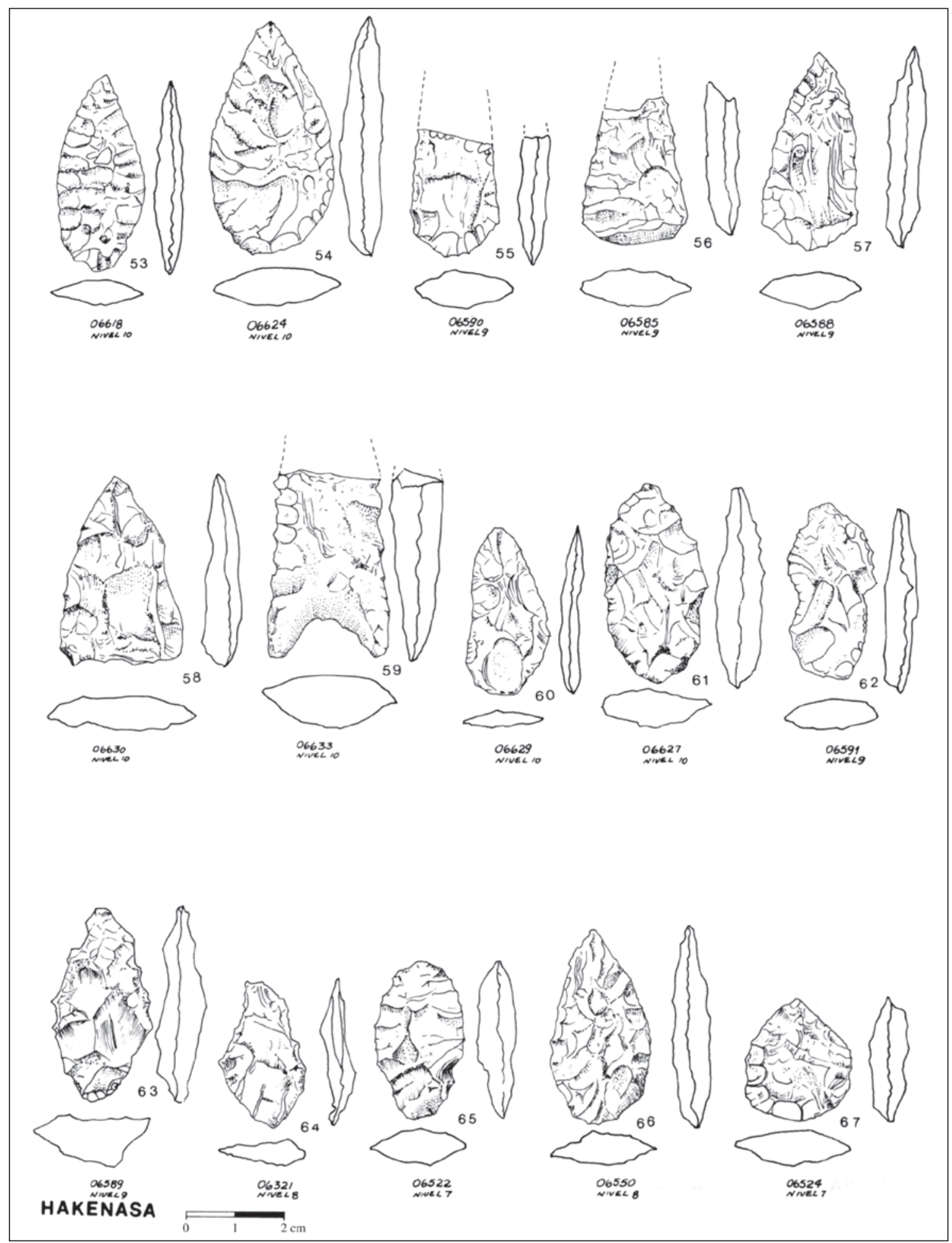

Figura 12. Artefactos indicadores del sitio Hakenasa, Componente Hakenasa III del Período Arcaico Tardío de la Puna Seca. 


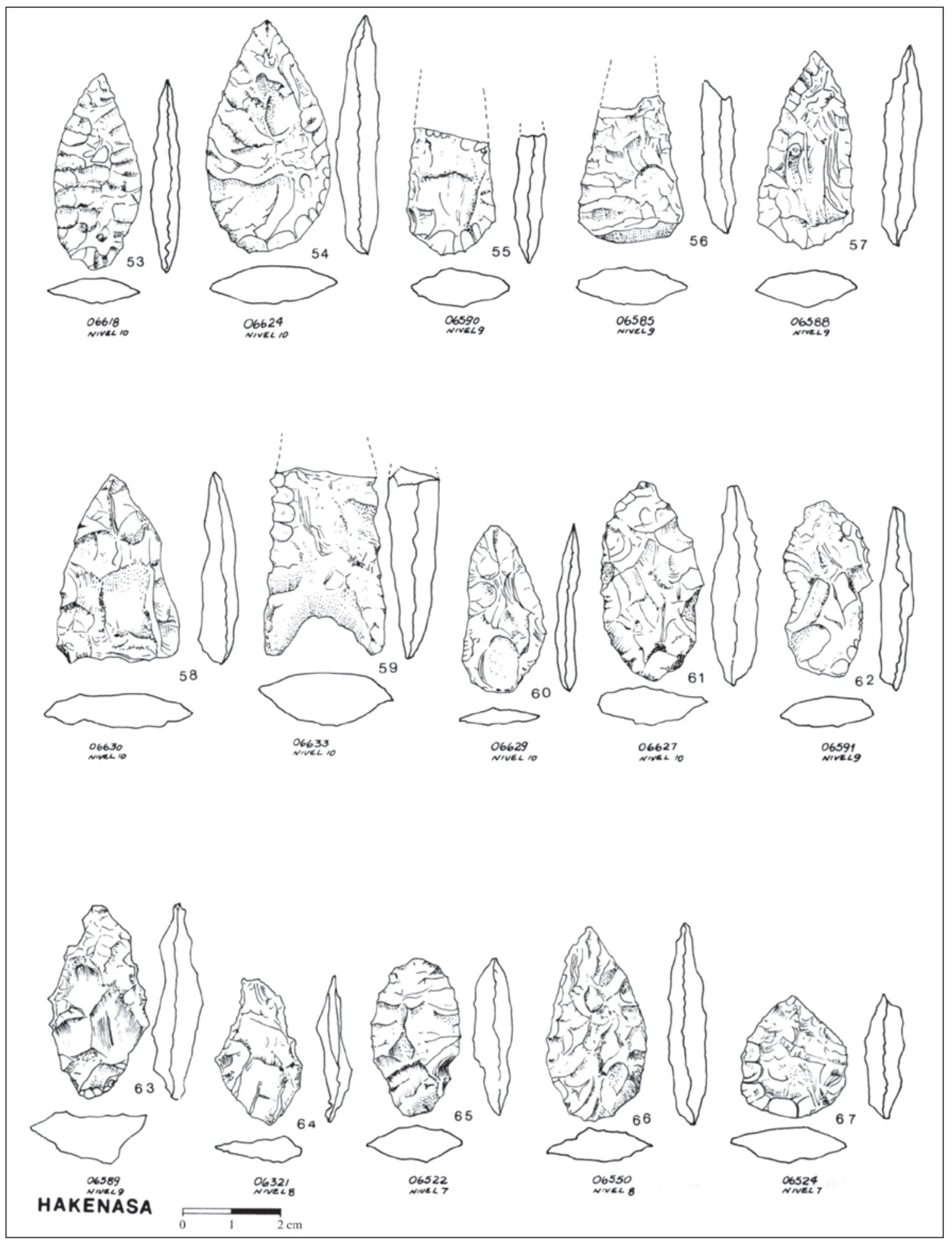

Figura 13. Artefactos indicadores del sitio Hakenasa, Componente Hakenasa III del Período Arcaico Tardío de la Puna Seca. 
formas foliáceas, ovaladas y triangulares con pedúnculo. Los cambios tecnológicos mencionados, parecen formar parte de un proceso de cambios socioculturales mayores, cuyos indicadores como algunos fragmentos de cerámica con desgrasante vegetal y una plaquita de oro datados en $2850 \mathrm{AP}$, aparecen bien representados en los estratos postarcaicos tardíos.

Tanto la cerámica con desgrasante vegetal como las puntas triangulares escotadas son comparables a similares registros obtenidos en Wankarani (Walter 1966: Figura 7a; Ponce 1970: 23 y 44, Figura 16). También las puntas son muy semejantes a aquellas obtenidas en Ichuña y Arcata, cuyas típicas formas se repiten en otros sitios de los Andes, no obstante que éstas provienen de una discutible excavación de prueba (Menghin y Schroeder 1957: 44).

En Hakenasa III el recuento general de los huesos señala un mayor predominio de animales mayores sobre los menores, en una proporción de dos a uno, aproximadamente. La presencia de abundantes desechos de percusión, instrumentos como perforadores y objetos de adornos (p.e., cuentas), indicaría que el sitio fue mucho más que paradero transitorio de caza. Se trataría más bien de un campamento semipermanente de cazadores, que viviendo una buena parte del año allí pudieron sumar a la elaboración de los instrumentos de caza, actividades artesanales que incluían la fabricación de collares y trabajo en cuero (perforadores). Articularon temporalmente los otros pisos de la Puna durante las estaciones más cálidas y húmedas (octubre-abril).

Distinta situación presentan una serie de ocupaciones más temporales en refugios y cuevas excavados en el piso de valles cordilleranos, entre los que se registran Puxuma, Piñuta, Guañure y Tojo Tojone. Con excepción de Tojo Tojone, las evidencias del Arcaico Tardío representan estratos de inicio de ocupación. Esta situación puede indicar una innovación de las estrategias adaptativas de los cazadores de este Período Arcaico Tardío, quienes comenzaron el uso intensivo de enclaves ecológicos que en los períodos anteriores fueron escasamente explotados.

Los tradicionales enclaves de la alta Puna y precordillera se continuaron ocupando incluyéndose el fondo de las profundas quebradas del piso de valles cordilleranos. Se recordará que en el Período Arcaico Temprano ocupaciones de este tipo no fueron constatadas.
Puxuma 1 forma parte de una serie de aleros ubicados en el fondo de la quebrada del mismo nombre, presenta dos fechas casi contemporáneas controladas del mismo nivel a comienzo de ocupación: 4010 AP y 4240 AP (ver Tablas 3 y 8). Los instrumentos diagnósticos y otros indicadores culturales se presentan en la Tabla 6. Los escasos restos de huesos señalan un predominio de animales mayores sobre animales menores. Hay pigmentos de color rojo y amarillo obtenidos de óxido de fierro y negro de manganeso (L. Figueroa, com. pers.), los que probablemente fueron usados durante el Período Arcaico Tardío para pintar las figuras que se encuentran más desdibujadas en las paredes del alero, cubiertas con una pátina de polvo, lo que indicaría una larga exposición a la intemperie. Entre las figuras que podrían corresponder al Arcaico Tardío se pueden mencionar algunas naturalistas de camélidos y la posible representación de un perro, ambas de color negro. Pigmentos de este color no se repiten en los estratos tardíos que se vinculan con el Período Incaico. Figuras naturalistas de camélidos de color rojo y amarillo aparecen superpuestas alternadamente, pero estos pigmentos se registran hasta épocas tardías, lo que dificulta su identificación cultural y cronológica.

Los escasos rasgos de este pequeño alero representarían un campamento temporal, para el aprovechamiento de recursos localizados de caza, con grupos conectados probablemente con algún campamento-base en la alta Puna.

Los otros tres aleros de Puxuma también presentan evidencias de arte rupestre. Recientes excavaciones practicadas en el alero Puxuma 2 arrojaron escasos restos de ocupación en un depósito de no más de $10 \mathrm{~cm}$ de espesor. Sin embargo, se obtuvieron allí las primeras evidencias de enterratorios en sitios arcaicos en las tierras altas de la Puna Seca, correspondientes a dos párvulos. El primero corresponde al cráneo aislado de un individuo de 5-6 años, basado en la dentadura (L. Vega, com. pers.). Fue sepultado con un collar de conchas de Oliva peruviana; conchas del mismo tipo fueron introducidas en los orificios de la nariz y un puñado de ellas fue colocado bajo su parietal izquierdo. Sobre el parietal derecho se ubicó una lasca grande de cuarzo. La cara está orientada hacia la costa. Entre las pocas rocas que formaban parte de la tumba, merece destacarse la presencia de un mortero invertido, lo que denota el carácter temporal y estacional de la ocupación. La misma orientación presenta el segundo individuo, de pocos meses de edad. Al contrario del anterior, el cuerpo fue 
enterrado sin la cabeza, en posición decúbito dorsal, con las piernas flexionadas, sobre una camada de vegetales. Una camada similar cubría el enterratorio apisonado con una mano de moler. Otros elementos diagnósticos asociados a estos enterratorios incluyen un pendiente de collar semicircular, de cobre no fundido, una punta pequeña triangular y una punta pequeña pentagonal, similar esta última a las de Patapatane y Hakenasa (Figura 11: 37 y 38). Una muestra de carbón obtenida de la superficie donde yacía el cráneo aislado, arrojó una fecha 3510 AP (ver Tabla 8).

Piñuta, una pequeña cueva en el piso valles cordilleranos, tiene una fecha de 3750 AP (ver Tablas 3 y 8) obtenida a comienzos de ocupación. Al igual que en Puxuma 1, pocos elementos diagnósticos están asociados con la ocupación arcaica tardía, presentados en la Tabla 6 .

El recuento de huesos muestra una leve superioridad de animales mayores (camélidos y venados) sobre los menores (roedores y aves).

También se registraron pigmentos de color amarillo y rojo, usados para pintar algunas de las figuras del panel localizado en la pared de la cueva. Se ha sugerido que una hilera de figuras humanas que corona el panel podría corresponder al Arcaico Tardío, representando el patrón de caza colectiva de arrinconamiento de animales (Santoro y Chacama 1982: Lám. 2; Santoro y Dauelsberg 1985).

Considerando la baja densidad de ocupación en el reducido espacio de la cueva, los episodios arcaicos tardíos ocurridos en Piñuta podrían corresponder a un campamento temporal usado para explotar los restringidos recursos de caza localizados en el cañón del piso cordillerano donde se ubica el sitio.

En Piñuta no hay una clara transición en la forma de los instrumentos como ocurre en Hakenasa, pero tampoco hay una clara interrupción entre los estratos arcaicos tardíos y los estratos siguientes correspondientes al Período Formativo Temprano. Sin embargo, la presencia de cerámica con desgrasante vegetal en los niveles correspondientes al Formativo Temprano, datados en 2540 y 2520 AP, muestran la culminación del proceso de cambios ocurridos durante el Arcaico Tardío.

Guañure corresponde a una ocupación de corta duración, en un pequeño alero localizado en un estrecho cañón del mismo nombre, en el piso de valles cordilleranos (ver Tablas 3 y 8). Se obtuvo una fecha de 4380 AP asociada a pigmentos rojos, que podrían datar las mal conservadas pinturas de las paredes del alero. Aunque no hay instrumentos de formas diagnósticas, la presencia de lascas y desechos de percusión y algunos huesos de animales mayores y menores demuestran que éste fue un refugio de uso temporal, correspondiente a un grupo muy reducido de cazadores de camélidos y venados, que todavía es posible encontrar en el área.

Un segundo sector excavado en Tojo Tojone (Dauelsberg 1983: 12) parece corresponder a otro campamento temporal de cazadores arcaicos tardíos, que aprovecharon la disponibilidad de venados, guanacos, roedores y roca volcánica del lugar (ver Tabla 6). La fecha radiocarbónica de 3740 AP no tiene asociaciones culturales (Dauelsberg 1983).

En las excavaciones practicadas recientemente en el sitio, a cargo del segundo autor, se ha identificado una punta lanceolada similar a aquéllas del Arcaico Tardío del sitio Patapatane. Esta punta junto a otra triangular con pedúnculo convergente y dos fragmentos de Choromytilus proviene de un estrato superior de la excavación que corresponde a una leve ocupación enrolada en el Período Arcaico Tardío (ver Tabla 6). Carbones obtenidos a este nivel entregaron una fecha de 2590 AP (ver Tabla 8), lo que representaría el límite tardío de este período (Santoro Ms).

Finalmente, los estratos superiores de la parte central de la estratigrafía de Patapatane (niveles F y G) representan el último sitio, bien documentado con ocupación arcaica tardía en la Puna Seca, con una fecha radiocarbónica de 4890 AP (Patapatane III) (ver Tablas 3 y 8). En la Tabla 6 se presentan los artefactos diagnósticos e indicadores culturales asociados a estos niveles en conjunto con los elementos de los demás sitios de esta época presentados en este capítulo.

Como en los sitios anteriores la proporción de huesos de animales mayores de Patapatane tardío supera en cantidad a aquéllos de especies menores. Se identificaron camélidos y una baja proporción de venados (Denis 1987 Ms). Estas evidencias sugieren que, durante el Arcaico Tardío, Patapatane fue probablemente un campamento estacional para el aprovechamiento de los recursos de caza de pradera y quebradas en el piso precordillera. Al igual que 
en Tojo Tojone, los restos de Choromytilus señalan algún tipo de contacto con la costa.

Para este período Patapatane III se han observado paneles de arte rupestre, entre los que se destaca un bloque asociado a la fecha señalada, con un diseño de tres figuras humanas en hileras, similares a los del sitio Piñuta. El desarrollo de estas expresiones, posiblemente de tipo mágico-religioso, mostraría parte de la complejidad de estas sociedades de cazadores tardíos en la Puna Seca, en sus expresiones transicionales tardías.

Los sitios arcaicos tardíos de la Puna Seca parecen representar un uso más intensivo en la utilización de diferentes enclaves en los tres pisos ecológicos. $\mathrm{Si}$ asumimos, a modo de hipótesis, que las condiciones climáticas en esa época ( $c a$.6000-4000 AP) fueron similares a las actuales, se podría esperar que durante las épocas normales de humedad los cazadores pudieron establecer sus patrones de movilidad sin fuerte presión estacional, ya que cada uno de los pisos ecológicos presentaba recursos favorables en cualquier época del año. Sin embargo, durante épocas de sequía, normales en el sistema climático actual, la situación debió ajustarse de manera más estacional, con campamentos de invierno probablemente localizados en la alta Puna (zona de bofedales), quedando reservado para la primavera y verano el acceso a los pisos de precordillera y valles cordilleranos.

En este contexto, los pequeños campamentos en los fondos de quebradas del piso de valles cordilleranos, orientados a la explotación temporal de recursos muy localizados de caza, y obtención de materias primas, podrían formar parte de una compleja red de campamentos con distintos tamaños y funciones, distribuidos a través del territorio, controlado por estos cazadores andinos del Arcaico Tardío típicos de la Puna Seca. A nivel de datos y conclusiones se deberán lograr nuevas tácticas metodológicas y teóricas para explicar en mejor forma la complejidad adaptativa y el desarrollo cultural alcanzado por estas sociedades de cazadores recolectores.

\section{Puna Salada}

Varios sitios de la Puna Salada correspondientes a cazadores tardíos documentan este período tardío. Se ha reconocido un patrón especializado de trashumancia estacional entre la alta Puna, quebradas intermedias y los oasis junto a las vegas del Salar de Atacama incluyendo el curso medio del río Loa (Núñez 1981, 1983 a y b) (ver Tablas 3 y 8). Los artefactos diagnósticos e indicadores culturales de estos sitios no son presentados en tablas como ocurrió con los sitios de la Puna Seca, ya que sus contextos son más conocidos y han sido recientemente revisados por el primer autor (1983 a y b). Sin embargo, los aspectos más significativos de aquellos sitios serán discutidos en esta sección incluyendo algunos datos que aún no han sido publicados. Las Tablas 3 y 8 presentan una lista completa de las dataciones radiocarbónicas y los sitios asociados al Período Arcaico Tardío.

De la quebrada y cerros de Tulan procedía una típica industria de láminas de datación, incierta, asociada superficialmente a morteros de hueco cónico (Le Paige 1970). En el borde sur de esta quebrada, siempre en cercanía a la vertiente homónima, a 2955 m de altura (flanco occidental de la Puna), hemos identificado varias ocupaciones arcaicas que se manifiestan a través de estructuras habitacionales disgregadas (emplantillados) y sectores con concentración de tallado lítico. En uno de estos sectores (locus de $200 \mathrm{~m}^{2}$ ), con preformas y desechos líticos, se registró un depósito estratigráfico con escasos implementos de molienda (morteros cónicos) y una densa acumulación de actividad de talla lítica. El sitio Tulan 51 presenta en el estrato I sedimentos eólicos mezclados con artefactos y desecho lítico, sin restos de fogones. El estrato II, se presenta con lentes de fogones, depósitos de cenizas, sedimentos eólicos, reflejando asentamientos leves y discontinuos, sobre la base estéril. Estos lentes contienen huesos muy fragmentados e industria lítica significativa. La base estéril fue socavada en varios sectores conformando bolsones que contienen fogones (carbón vegetal), huesos y artefactos predominantes de láminas (estrato III). A juzgar por el contenido del bolsón principal se advierte una clara asociación entre restos de camélidos, carbones y láminas líticas en proceso de elaboración y usadas, por lo que se puede sugerir que en torno a estas depresiones se realizaron actividades de cocina con preparación y utilización de artefactos in situ. Una muestra del fogón principal se dató a los 4990 AP (ver Tabla 8), tiempo en que determinamos la utilización de un conjunto de artefactos típicamente laminadores elaborados en toba desvitrificada o Tulan (Figura 14).

El test estratigráfico proporcionó 411 artefactos sujetos a clasificación mezclados con $2600 \mathrm{gr}$ de fragmentos laminares no modificados y desechos de percusión 


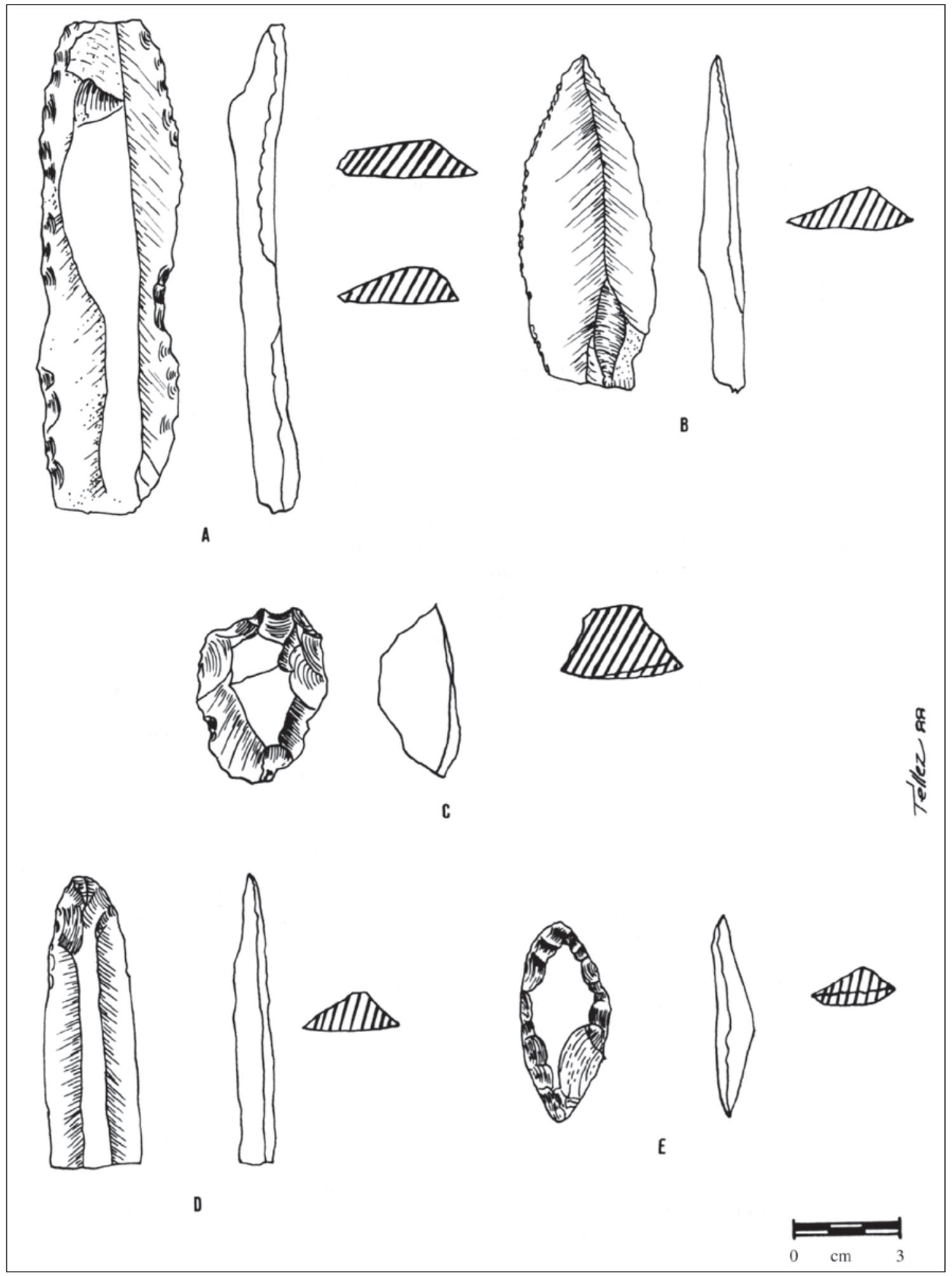

Figura 14. Industria del sitio Tulan 51 (comienzo de ocupación): A) Raedera-muesca en lámina de toba Tulan;

B) Cuchillo bilateral en lámina de toba Tulan; C) Preforma de raspador en tres lados; D) Lámina con modificación distal de toba Tulan; E) Raedera foliácea en lámina de toba Tulan. 
sobre láminas, y en menor proporción, desperdicios de lascas finas de sílice, cuarzo y obsidiana. Se cuantificaron $600 \mathrm{gr}$ de restos óseos con predominio de camélidos sobre roedores. Se clasificaron 29 rasgos líticos diferenciados que a continuación se reseñan. En general, es común el uso de láminas, recuperadas desde las canteras situadas al norte de la quebrada y de algunos afloramientos locales. La relativa ausencia de núcleos sugiere que eran trasladadas a manera de preformas para ser finiquitadas en los talleres-campamentos y campamentos específicos como Tulan 52. Junto a esta industria se destaca con menor frecuencia el uso de obsidiana, cuarzo, sílice y basalto, orientados a elaborar implementos sobre lascas refinadas, entre los que se destacan los típicos microlíticos similares al Complejo Chiu Chiu (27051675 AC), aunque éstos se recobraron sobre el bolsón fechado. En términos generales, los registros líticos similan a los ubicados en el campamento cercano (Tulan 52), pero la predominancia de abundante talla de láminas se explica a raíz del carácter de sitio-taller, más que un campamento propiamente habitacional (ausencia de estructuras), especializado en la labor de reducción de láminas preformas. Estas actividades reflejan un alto índice de piezas líticas rechazadas, al tanto que los escasos restos óseos demuestran el carácter transitorio del establecimiento. Las evidencias de conchas de mar y de microlíticos, similares a los registrados en el río Loa Medio, caracterizan una situación de contacto con otros ambientes más bajos, otorgando otra similitud con el yacimiento Tulan 52. Para los efectos de secuencia se atribuye a esta estación-taller, como uno de los momentos iniciales del Complejo Tulan que a continuación se presenta (patrón de caza especializada).

Dentro del Período Arcaico Tardío se destaca ahora al campamento Tulan 52, con dos fechas cercanas a 4340 y 4270 AP (ver Tablas 3y 8). De acuerdo al total de artefactos clasificados se observa el predominio de puntas lanceoladas o foliáceas de diversos tamaños. Estas coexisten con puntas tetragonales o de pedúnculo agudo y aleta desde el comienzo de ocupación, aunque obviamente el patrón pedunculado en general es de muy baja frecuencia. El total de puntas es del orden de los 586 especímenes, segregadas en los siguientes grupos: a) Puntas lanceoladas con 17 subtipos (556 especímenes); b) Puntas triangulares con tres subtipos (cinco especímenes); c) Puntas pedunculadas con cuatro subtipos (25 especímenes).
El total de los instrumentos cortantes apoya las actividades de caza inferidas por las puntas a raíz de una profusa actividad de faenamiento que arroja un total de 1175 especímenes, segregados en los siguientes grupos: a) Cuchillos bifaciales en lascas rebajados a presión con 17 subtipos (461 especímenes); b) Cuchillos en láminas modificados a presión (111 especímenes); c) Cuchillos en láminas no modificados con uso en filos naturales (498 especímenes); d) Cuchillos en lascas no modificados con filos naturales cortantes y usados (105 especímenes).

Las raederas cubren 20 subtipos (273 especímenes), al tanto que los cuchillos-raederas con seis subtipos (83 especímenes), demuestran cifras menores a las precedentes. Los perforadores grandes con cuatro subtipos (28 especímenes), y los perforadores microlíticos con dos subtipos (69 especímenes), sugieren actividades vinculadas con el subproducto de la caza con un rango menor en popularidad, sumando un total de 97 especímenes. Los perforadores aquillados microlíticos, tanto preformas como terminados en sus dos subtipos, totalizan 113 especímenes, sugiriendo actividades regulares y significativas en torno a los subproductos de caza.

Los raspadores y muescas con 14 subtipos totalizan 175 especímenes, al tanto que otros microlíticos cortantes, para raer y raspar (algunos retomados de otros artefactos), a través de tres subtipos totalizan 98 especímenes, reforzando lo anteriormente expuesto.

Los tajadores y percutores con dos subtipos totalizan 29 especímenes, cifra que parece bastante baja en lo que respecta a la presencia de percutores en trabajos de terminación de preformas, pero el registro de múltiples huesos con estriamientos a manera de retocadores equilibra de algún modo esta cifra.

Los implementos de molienda muestran siete subtipos en manos que totalizan 57 especímenes, vinculados con los morteros de hueco cónico (12 especímenes), por lo que las prácticas de molienda, ya sea para preparación de alimentos, o como maceración de pinturas y huesos, alcanza una representación regularmente destacable.

Considerada la industria del Complejo Tulan como un todo, se advierte el uso predominante de más del 50\% de artefactos elaborados en láminas Tulan, trasladadas al campamento, donde se tallaron 


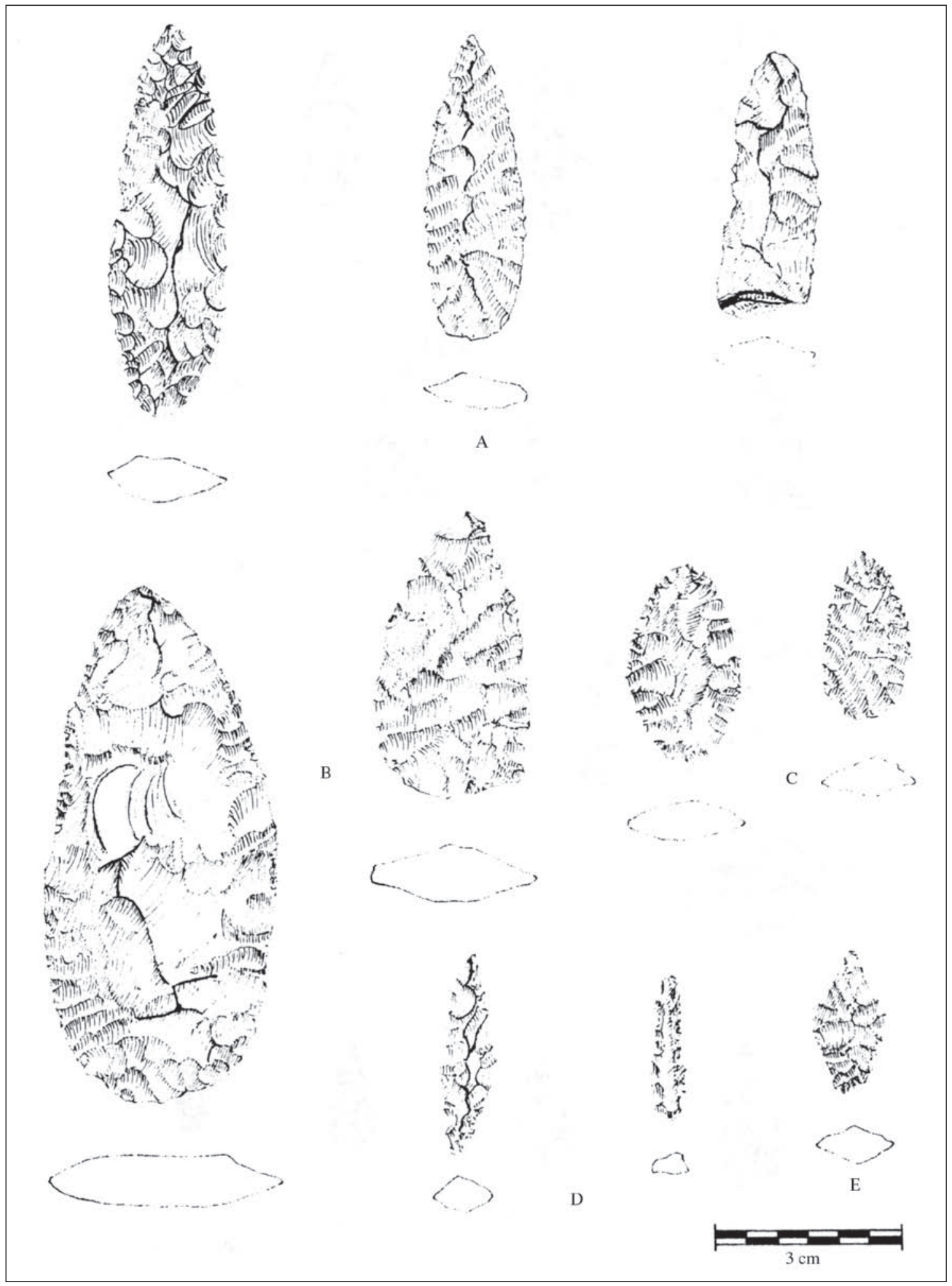

Figura 15. Industria lítica del sitio Tulan 52 (comienzo de ocupación): A) Puntas bifaciales foliáceas; B) Cuchillos bifaciales asimétricos; C) Puntas bifaciales pequeñas; D) Perforadores de cuerpos estrechos, sección triangular; E) Perforador de cuerpo extendido. 
implementos de mayor tamaño, mientras que con lascas de cuarzo, calcedonia, sílice y vidrio volcánico, se prepararon instrumentos más pequeños y refinados (Figura 15).

Entre los materiales misceláneos se registran esferoides pulidos, fragmentos basálticos pulidos, trozos de piedras pómez con estrías vinculadas con el proceso de rebajamiento de los bordes de los instrumentos líticos. Se encuentran, además, pequeños depósitos cilíndricos de piedra pómez, micromorteros de granito y pómez, piedras con estrías para afilar o pulir, recipientes cilíndricos de hueso y diversas conchas del Pacífico (Oliva peruviana, Pectén, Concholepas concholepas, Semele y Choromytilus). Es destacable el hecho de que estas conchas demuestran valores de estatus a través de su uso en cuentas de collares, aspecto que se enfatiza con el uso de cuentas de mineral de cobre y líticas (hay registros de mica brillosa con fines seguramente similares).

En términos generales existe una continuidad de la industria lítica entre la Zona Temprana, Intermedia y Tardía, constituyendo un desarrollo tecnológico funcional homogéneo, incluso durante la Zona Tardía cuando las habitaciones se habían cubierto de desperdicios. De modo que es probable que las últimas ocupaciones de este mismo patrón hayan utilizado viviendas más superficiales que se observaron a través de concentraciones de bloques, industria lítica e implementos de molienda dispuestos sobre la superficie. Precisamente la tradición lanceolada y los implementos de molienda perduran en todo el depósito. Algo similar ocurre con los típicos instrumentos lanceolados.

En suma, el campamento-taller Tulan 51 y Tulan 52 (conglomerado residencial) como ejemplo este último de asentamiento más sedentario, con viviendas circulares aglutinadas, concentraron cazadores recolectores que explotaban los recursos de la quebrada Tulan, la cual conecta la alta Puna con el oasis de Tilomonte. En la industria lítica destaca el uso de obsidiana andina para la elaboración de finos instrumentos y bloques con ranuras como afiladores. Elemento distintivo ausente en la Puna Seca son los típicos morteros de hueco cónico con varios tipos de manos usados eventualmente tras la preparación de alimentos, molienda de pigmentos y huesos. A pesar que no se registraron restos de plantas en las excavaciones, se lograron recuperar con técnicas de flotación evidencias de semillas de quínoa (Chenopodium sp.), que por su analogía a las actuales se trataría tentativamente de alguna especie doméstica (Núñez Ms).

El intenso uso de obsidiana andina en estos sitios asegura que la explotación de la alta Puna fue constante, a través de campamentos de verano (Meniques y Miscanti; Niemeyer y Schiappacasse 1976), mientras que los desechos de camélidos adultos sugiere que los hábitos de vida semisedentarios se apoyaban en cacerías especializadas, recurrentes en el fondo de la quebrada (chacu), suplementados de roedores locales: Lagidium sp., Ctenomys sp., Chinchilla sp. y aves (Núñez 1986 Ms).

Estas agrupaciones articulaban los ambientes de oasis (Tilomonte) y las vegas del Salar (Tilocalar), con artefactos típicos procesados con toba Tulan, procedente de las canteras localizadas al norte de quebrada Tulan.

En general, el esquema de trashumancia propuesto para el transecto Tulan (ver Figura 3) sugiere que los cazadores recolectores del Período Arcaico Tardío de la Puna Salada ubicaron sus campamentos-bases en la quebrada intermedia cerca del curso de agua. Durante el verano habrían subido a la alta Puna para cazar y obtener obsidiana por los campamentos de Miscanti y Meniques (Niemeyer y Schiappacasse 1968). Otro tanto habría ocurrido al final del verano, en la desembocadura de la quebrada, en torno a la recolección de algunos frutos de chañar y Prosopis sp. Este esquema habría permitido sostener los campamentos de vida semipermanente localizados en las quebradas que unen a la alta Puna, y en las vegas y lagunetas del Salar de Atacama (Núñez 1981, 1983 a y b).

En coexistencia con el Complejo Tulan se dispone Puripica, con indicadores muy singulares, datado entre 4815-4050 AP (ver Tablas 3 y 8). La industria de Puripica se caracteriza por el empleo de lascas más que láminas, alternándose diversas preformas con instrumentos terminados a consecuencia de los trabajos de finiquito de herramientas in situ. La abundante presencia de materia prima de basalto y en menor proporción de sílice, cuarzo y vidrio volcánico, acentúan con mayor rigor la utilización de lascas, puesto que el área es potencialmente rica en depósitos basálticos (Figura 16). En términos generales, los artefactos de Puripica son más reducidos que los de Tulan y no hay cambios tecnológicos ni funcionales a través de los estratos, por lo que se 


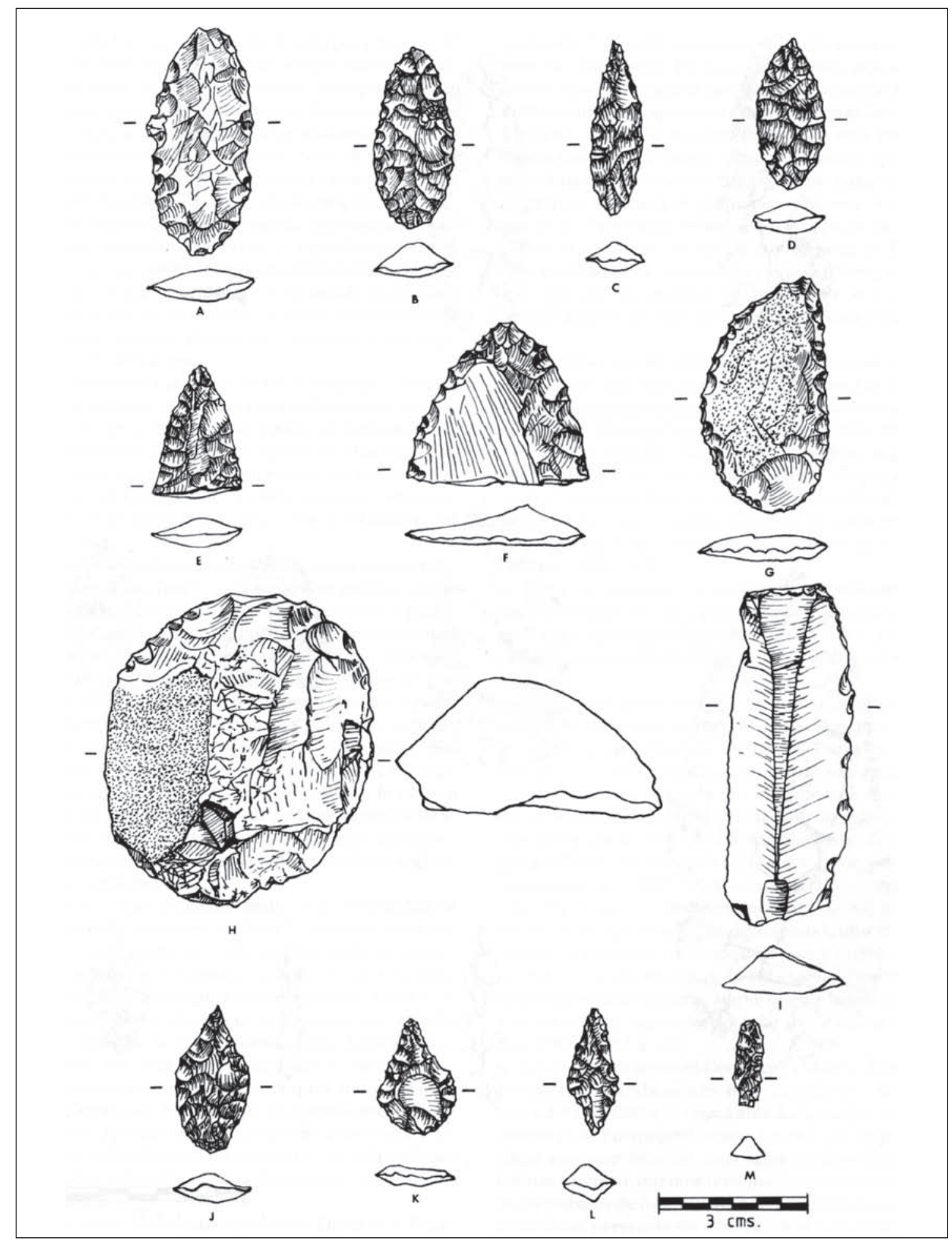

Figura 16. Industria lítica del sitio Puripica 1 (comienzo de ocupación): A) Punta basáltica bifacial con denticulaciones; B) Punta foliácea denticulada bifacial de obsidiana; C) Punta foliácea bifacial estrecha de obsidiana; D) Punta bifacial basáltica; E) Vértice bifacial de cuchillo simétrico (sílice); F) Vértice de cuchillo simétrico (basalto); G) Cuchillo bifacial asimétrico (sílice); H) Raspador plan convexo semidiscoidal (basalto); I) Lámina con bordes modificados (basalto); J) Punta bifacial retomada con vértice biconvexo (obsidiana); K) Perforador de cuerpo ancho (sílice); L) Perforador de sección bitriangular (sílice); M) Perforador de sección triangular (sílice). 
debe entender que el yacimiento presenta un desarrollo continuo a través de un lapso de a lo menos dos ocupaciones con estructuras aglomeradas. Las puntas de proyectil, con 10 subtipos, suman 133 especímenes con un patrón lanceolado dominante, que coexiste desde el comienzo de ocupación con fragmentos de puntas tetragonales, pero de baja frecuencia. Las actividades de golpes tajantes y percutores persisten en toda la ocupación con 49 especímenes. Comparativamente, el trabajo de raspado es de baja frecuencia a través del total de la ocupación con 54 especímenes, correspondiendo a una actividad menor de las de raído que suman 76 especímenes. La acción perforante, a través de microlíticos, adquiere un significado mayor que las de raspado (50 especímenes). No obstante, las funciones cortantes, del orden de los 230 especímenes, señalan una intensa actividad de faenamiento de animales que no guarda proporción con la relativa baja frecuencia de puntas de proyectiles (133 especímenes). Por estas razones, se sugiere que los grupos arcaicos de Puripica contaban con alimentos cárneos abundantes, sin énfasis en una caza intensiva, por lo que las primeras prácticas de crianza de camélidos se habrían logrado como un régimen primariamente complementario a las labores de cacería. Este acercamiento controlado sobre los camélidos parece ser la causa de que solamente en este sitio aparezcan grabados de camélidos con un estilo homogéneo (Figura 17).

Se calcula que un total de 50 estructuras habitacionales y secundarias (circulares y aglomeradas), algo más que Tulan 52, conforman el total del campamento, situación que refleja un alto nivel de estabilidad que estaría dado fundamentalmente por la captura y domesticación de camélidos andinos, complementados de animales menores como roedores y aves. Hasta hoy sobrevive aquí un tipo de vicuña de mayor alzada y fibra distinta al resto de las vicuñas del norte de Chile (A. Santoro, com. pers.), no obstante pertenecen a una misma especie.

Estos grupos se trasladaban hacia la alta Puna para intensificar las prácticas de caza complementaria y captura de camélidos, oportunidad en que recogían vidrio volcánico (obsidiana), que era utilizado para realizar instrumentos presionados pequeños y de funciones más sofisticadas. También entraron en contacto con los grupos arcaicos del momento clímax y terminal del Complejo Tulan, a raíz del registro de algunas láminas elaboradas con la típica toba localizada en el contorno de la quebrada de Tulan.
La utilización de microlíticos aquillados, similares al Complejo Tulan (3040-2390 AC) y Chiu Chiu (2715-1675 AC, ver Tabla 8), vinculados mutuamente con dataciones sincrónicas, también habla a favor de contactos con grupos entre el borde sur del Salar al río Loa medio, pasando por los arroyos afluentes del río San Pedro y Loa, respectivamente.

Entre los materiales misceláneos de Puripica se advierte el uso de artefactos óseos de extremos aguzados y redondeados, a través de toda la ocupación, al tanto que algunos fragmentos de carbonato de cobre y cuentas líticas sugieren ciertas prácticas de estatus similares al Complejo Tulan. Se han registrado conchas del Pacífico (Pectén, Concholepas concholepas, Choromytilus), prácticamente en toda la ocupación, con mayor énfasis en el estrato II, también utilizadas para adornos de collares. Al igual que el Complejo Tulan, durante el clímax y momento final de este asentamiento se habría intensificado la movilidad hacia las tierras bajas, con contactos a través del río Loa, para proveerse de productos de estatus obtenidos en la costa del Pacífico.

Se sugiere que los grupos de Puripica fueron contemporáneos al momento clímax y terminal de Tulan y se habrían especializado en la captura de camélidos andinos en un ambiente sumamente propicio, iniciando de esta manera ciertos reemplazos en el patrón de subsistencia cazador-recolector arcaico a través de prácticas experimentales de control de camélidos, esta vez domésticos, aunque las prácticas de caza continuaron pero con menor énfasis que las registradas en el Complejo Tulan.

En suma, este circuito trashumántico se ha identificado en la quebrada intermedia del río Puripica (3200 m), en el extremo noreste de San Pedro de Atacama, en un ambiente forrajero más rico en relación a Tulan. $\mathrm{El}$ asentamiento comparte una industria lítica y de molienda similar a la de Tulan, aunque hay un notable déficit de láminas, reemplazadas por lascas de basalto locales. Destacan puntas lanceoladas, cuchillos, perforadores, microlíticos y morteros de tipo cónico.

Considerando la alta frecuencia de cuchillos, en relación a la baja frecuencia de puntas, el primer autor ha sugerido que había un mayor énfasis en actividades de faenamiento y preparación de pieles de camélidos al mismo tiempo que se producía un descenso en las prácticas de caza. Hasta ahora este territorio presenta una alta concentración de 


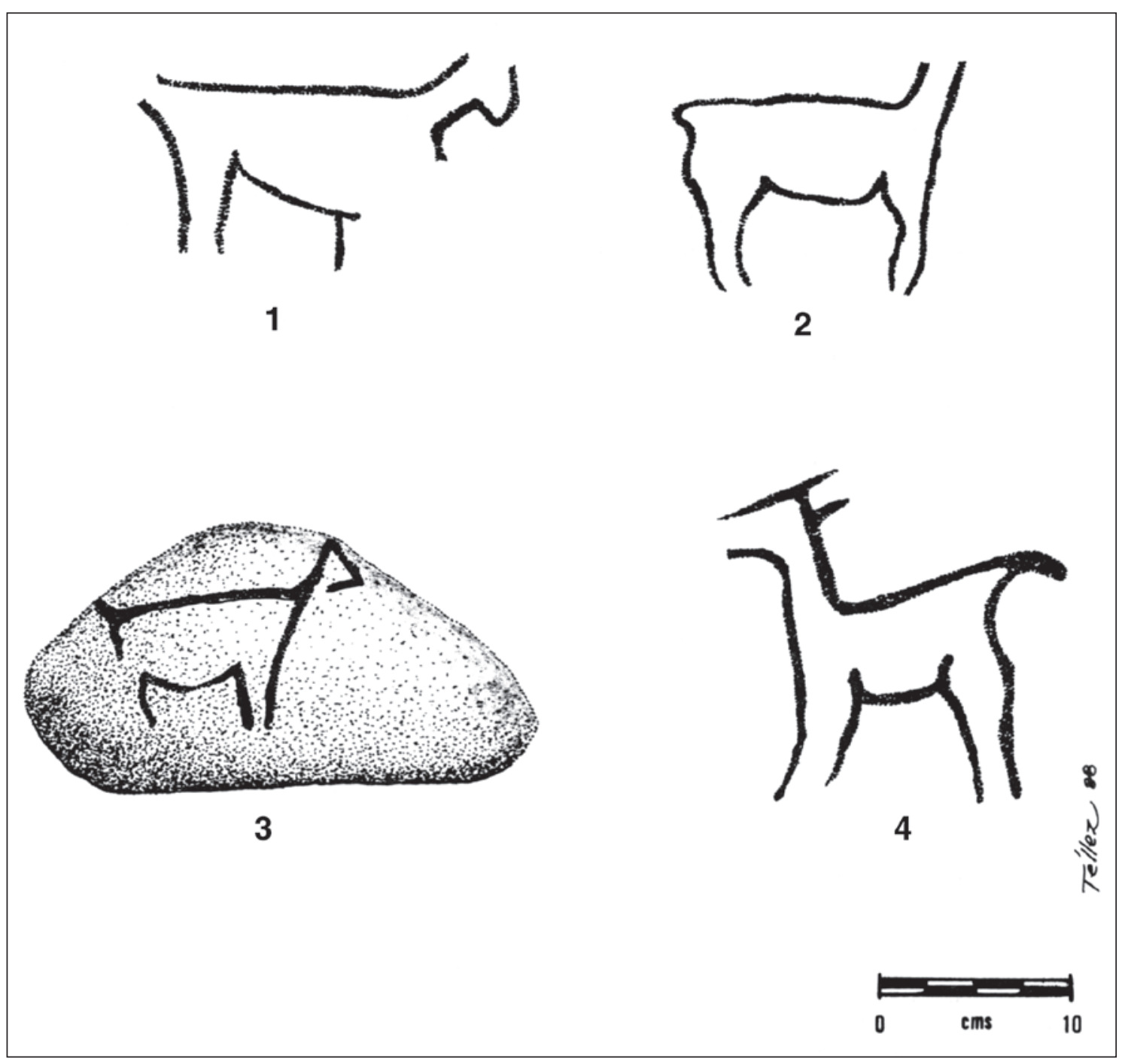

Figura 17. Grabados de camélidos en bloques muebles del sitio Puripica 1: 1) Bloque asociado al I nivel de ocupación del recinto excavado; 2) Grabado ubicado en la superficie del sitio; 3) Bloque grabado asociado a la base de un recinto testeado (comienzo de ocupación); 4) Bloque grabado asociado al II nivel de ocupación de un recinto testeado.

Vicugna vicugna, y sostiene crianza de llamas a lo largo del río y cerros con forraje estacional de alta perdurabilidad. La gran cantidad de residuos óseos de camélidos tiernos y neonatos (evidencia osteométrica) ha planteado una incipiente economía productora de carne. La crianza en cautiverio habría motivado patologías que se reflejaron en la alta tasa de mortalidad precoz. Esta evidencia coincide con las nuevas funciones de la industria lítica ya mencionada y con el registro único de bloques muebles con grabados de camélidos, vinculados a un culto auspiciatorio y de fertilidad en torno a llamas domesticadas. Probablemente Puripica fue más usado durante el verano (reproducción de camélidos), complementado con campamentos menores ubicados a lo largo de la quebrada y aun hacia el Loa medio donde sus rasgos coinciden con las evidencias de los campamentos del Complejo Chiu Chiu. Por otro lado, la similitud del estilo de los grabados de camélidos permite sugerir conexiones con el sitio Kalina del alto Loa, sumándose las analogías de los recintos habitacionales, dataciones radiocarbónicas y conchas del Pacífico (Aldunate et al. 1986). 
El Complejo Chiu Chiu se había vinculado con un patrón de trashumancia dentro de un área más restringida y correlacionada con fluctuaciones del medio ambiente de acuerdo a Druss (1977). Se localiza en el curso medio del río Loa y está datado entre 4665 AP y 3625 AP (ver Tabla 8). Se registraron más de 70 sitios correspondientes a pequeños campamentos transitorios y semipermanentes o más complejos. Se ha sugerido que durante condiciones más húmedas, se mantuvieron ambientes cenagosos que permitieron mayor abundancia de recursos de caza; mientras que en los períodos secos se abandonaron para recurrir a nichos más altos. Estos cambios ambientales no habrían sido de tipo estacional, sino más bien cíclicos, comprometiendo algunos años o varias décadas. Entre la industria lítica de estos sitios destacan puntas lanceoladas, doblespuntas simétricas, cuchillos bifaciales, microlíticos de sección triangular e implementos de molienda, asociados a una amplia variedad de recursos consumidos, tales como: camélidos, roedores, aves, pescados y semillas.

La presencia de lana parecía indicar una incipiente domesticación de camélidos, cuyo proceso es interpretado por Druss (1977) como consecuencia de una alta especialización en los patrones trashumánticos de caza y recolección. Varias bandas habrían aprovechado los recursos intercalados entre el río Loa medio y sus áreas altas, pero no se conocían conexiones bien documentadas con asentamientos sincrónicos de mayor altitud.

Las nuevas evidencias de Puripica han revalorado los vínculos entre el Complejo Chiu Chiu y el acceso a la domesticación de camélidos.

Las viviendas circulares socavadas, puntas foliáceas, implementos de molienda y microlíticos comunes en Puripica y Chiu Chiu, han permitido ahora sugerir que estas comunidades de cazadores recolectores formaron parte de un patrón trashumántico que involucraba cacerías de camélidos en la alta Puna, domesticación de llamas en las quebradas intermedias y mantención de rebaños, caza y recolecta vegetal en las vegas del río Loa, cuando estos recursos no estaban bajo un período de sequía (Núñez 1986 Ms).

Estas actividades protopastoriles estarían configurando los inicios de una complejidad creciente de repercusión regional si se considera que la presencia de conchas en Puripica y Chiu Chiu indicarían contactos con recursos alternativos del litoral (Druss 1977; Núñez 1980; Hesse 1982).

Por su parte, los sitios Isla Grande y Confluencia, ubicados en el curso medio del río Loa, podrían mostrar los inicios del patrón Puripica-Chiu Chiu. Isla Grande está datado en $6008 \mathrm{AP}$ en tanto que Confluencia tiene una fecha de 5380 AP (ver Tablas 3 y 8). En Isla Grande destacan puntas lanceoladas e implementos de molienda, asociados a abundantes restos de plantas y huesos de camélidos. En Confluencia se hallaron también viviendas semisubterráneas asociadas a puntas lanceoladas y pedunculadas, grandes cuchillos de hojas anchas lanceoladas y de formas triangulares (Lanning 1968). Finalmente, se ha sugerido que estos episodios representan un desarrollo, tal vez inicial, de una eficiente adaptación trashumántica controlando pisos entre el curso medio del río Loa y nichos más altos en la Puna Salada, basada en la caza de camélidos, avifauna y domesticación (?), aunque estos sitios limitan los períodos Arcaico Medio y Tardío, sin asegurarse hasta ahora sus vínculos más específicos con los episodios tardíos de Puripica-Chiu Chiu.

El análisis osteométrico de los sitios Tulan 52, Puripica 1 y Tambillo 1 posibilita documentar el problema de domesticación. El Complejo Tulan, de acuerdo a su equipamiento lítico, se apoya en cacerías locales con suplemento de horticultura de quínoa, mientras que Puripica representa actividades de caza-recolección, con indicios iniciales de actividad pastoril. Tambillo podría representar el estadio de desarrollo pre Tulan y Puripica, en momentos estacionales en que ocupan espacios bajos, donde se reflejan claramente sus logros cazadores. De esta manera, el desarrollo arcaico tardío Tulan 52 y Puripica 1, de las tierras medias demostraría, entre los 2000 a 3000 años AC, un proceso de caza especializada, complementada de horticultura, a través de grupos trashumantes que distribuían sus campamentos-bases en las quebradas intermedias, articulando a través de diversas temporadas el perfil alta Puna-cuenca de Atacama. Este proceso de adaptación circumpuneña varió durante la etapa tardía hacia el control de camélidos, disponiendo las bases de actividades protopastoriles (Puripica).

Los estudios de Bryan y Paula Hesse (1979) se han fundamentado en un total de $129 \mathrm{k}$ de residuos óseos de Tulan 52, de Puripica 1, y de Tambillo 1 (Tabla 7). 


\begin{tabular}{|l|r|r|r|}
\cline { 2 - 4 } \multicolumn{1}{c|}{} & Tulan 52 & Puripica 1 & Tambillo 1 \\
\hline Camélidos & 12096 & 3.426 & 1047 \\
Roedores & 2067 & 825 & 1085 \\
Aves & 101 & 239 & 76 \\
$\mathrm{~N}^{\circ}$ de cuadrículas de $\mathrm{m}^{2}$ & 28 & 27 & 42 \\
\hline
\end{tabular}

Tabla 7. Distribución de los fragmentos óseos.

Los análisis demuestran claramente que en Tulan 52 y Tambillo 1, la proporción de camélidos es del orden de dos grandes por uno pequeño, en tanto que en Puripica la situación es al revés, de modo que si se toma en cuenta las conclusiones tecnológicas, en el caso particular de Puripica (prioridad en las actividades de faenamiento más que en las de caza), se puede establecer que la domesticación de camélidos se inició hacia los 2000 años AC en ciertos enclaves de alturas subandinas en el ámbito circumpuneño. De acuerdo a esto, los grupos del patrón Puripica reflejan el acceso hacia un nuevo modelo económico en los primeros bloques grabados con diseños de camélidos registrados exclusivamente hasta ahora, en los sitios arcaicos del total de las tierras altas del norte de Chile.

La combinación de caza de camélidos, aves y roedores, de acuerdo a la variación altitudinal, agregado a la domesticación de camélidos (de acuerdo a las evidencias de Puripica) se involucra con la problemática de la identificación y cronologización de diversos locus de domesticación de plantas, camélidos y roedores andinos. Esto debió ocurrir tanto en subáreas nucleares de los Andes Centrales (p.e., Puna de Junín) como en aquellas subáreas periféricas (p.e., Circumpuneña). La presunción de que la llama surgió en este contexto no nuclear, a lo menos a nivel del Período Arcaico Tardío, como un cambio revelador es ahora más real a la luz de la conexión Puripica-Chiu Chiu-Kalina en la fricción alta de las subáreas Valles Occidentales con la Circumpuneña. Es probable que estos episodios hayan ocurrido en la Puna Seca, pero las evidencias de domesticación en esta parte de la Puna aún exigen mayor investigación.

\section{Sumario y discusión}

La nueva información arqueológica presentada, correspondiente a los períodos Arcaico Temprano y Tardío y las reseñas sobre el Período Arcaico Medio, muestran en general una identidad de formas en las industrias. Los procesos socioculturales de las sociedades de cazadores recolectores que habitaron la Puna Seca y Salada, en lo que corresponde actualmente a los territorios del sur peruano y norte de Chile, tienden a su vez a observarse homogéneos. La sugerencia de Schiappacasse y Niemeyer (1975) en el sentido que los pisos altos son un factor de unificación cultural parece corroborarse con la data presentada.

Sin embargo, estudios más recientes que han incorporado datos faunísticos, florísticos y medio ambientales permiten distinguir patrones diferenciados dentro de las dos punas. Siguiendo la información florística disponible para el área, se ha sugerido correr el límite de la Puna Seca, definido por Troll (1958), hasta las localidades de Cariquima e Isluga. Mientras que la Puna Salada o Desértica abarcaría desde el sur de Cariquima-Isluga hasta el borde meridional de la Puna de Atacama.

Para la I Región, Puna Seca se ha definido en términos generales un patrón persistente semitrashumántico de caza, considerando la ausencia de recursos significativos de recolección (p.e., algarrobo). La presencia de un ambiente rico en forraje en los tres nichos que componen esta área: precordillera, valles cordilleranos y alta Puna concentraron, aunque no en exceso, pero sí permanentemente, recursos diversificados de caza representados por camélidos, venados, roedores y aves. Estos recursos, contrariamente a lo que ocurre en la Puna Salada, no presentan una marcada alternancia o movilidad estacional.

Se ha presentado a la Puna Seca como un eje nuclear a base de enclaves con bofedales localizados en el piso alta Puna, donde se concentran recursos estables todo el año. Es decir, que las condiciones de la Puna Seca la hacen habitable para hombres y animales en cualquier época del año. Considerando estos elementos en su conjunto se formula la siguiente reconstrucción de estilos de vida. Desde épocas tempranas holocénicas, agrupaciones de cazadores habrían ubicado sus campamentos-bases en refugios y aleros alrededor de los bofedales durante el invierno (mayo-septiembre). Durante esta estación seca y helada, en los pisos valles cordilleranos y precordillera, las praderas pierden gran parte de su potencial por lo que los animales tienden a dispersarse, mientras el bofedal mantiene una adecuada concentración de recursos, entre los que destaca la vicuña.

La ubicación de los sitios tempranos (ca. 95008000 AP) en enclaves sensiblemente más bajos, dentro de la alta Puna, en la Puna Seca, parece 
demostrar que durante la estación húmeda y cálida, los cazadores pudieron articular enclaves más altos dentro de este piso, como así también en los más bajos, especialmente en espacios restringidos de praderas en el piso precordillerano.

Cronológicamente consideradas ambas regiones in toto, Puna Seca y Salada, se propusieron cinco períodos (ver Tabla 2). El más temprano, Paleoindio, sin registros cronoestratigráficos eventualmente algo anterior a $c a .11000 \mathrm{AP}$. La tendencia a ocupar lugares abiertos y el uso de puntas triangulares por parte de los cazadores del Período Arcaico Temprano sugiere cierta derivación de algún ancestro paleoindio no bien identificado. De no ser válida esta hipótesis, el primer poblamiento debió corresponder a algún flujo arcaico temprano como los cazadores de la Fase Tuina.

En efecto, el segundo Período Arcaico Temprano se separa en una fase temprana y otra tardía. La primera, denominada Tuina, presenta un rango temporal en la Puna Salada, entre 11000-9000 AP. En la Puna Seca, las evidencias de Toquepala, Tojo Tojone y Las Cuevas sugieren un límite más temprano (ca.9500 AP) para el término de esta fase, dentro de un estilo de vida semitrashumántico más regularizado.

La Fase Tuina, en cambio, se caracteriza por un patrón de menor movilidad interambiental no regularizado, tal vez, dando origen a un régimen trashumántico muy incipiente, articulando gradualmente el perfil regional in toto (Núñez 1983a, 1983b). Se trata de cazadores de camélidos que optan por alturas moderadas inmediatamente prealta Puna, estableciendo un hábitat particular en las quebradas intermedias y bajo los 3500 m (Núñez 1983: 60). Se considera que los pisos más altos sobre $3500 \mathrm{~m}$ habrían sido inhóspitos (helados y secos) para el estacionamiento sostenido de ocupaciones arcaicas tempranas durante las estaciones frías. Este patrón de ocupación se advierte funcional en la Puna Salada de Atacama, particularmente relacionado con los episodios sensiblemente más tempranos de Tuina y San Lorenzo (ca. $10500 \mathrm{AP}$ ), configurando un temprano flujo circumpuneño que involucró a otras ocupaciones de la vertiente oriental.

En cambio, la presencia en la Puna Seca de tres sitios ubicados en distintos pisos dentro del área, con fechas que se agrupan alrededor de 9500 AP (p.e., Toquepala, Tojo Tojone, Las Cuevas) sugiere que estos cazadores comenzaban a ocupar con más regularidad los ambientes de altura, al mismo tiempo que demarcaban un patrón de movilidad ambiental, sin dependencia estricta de las variaciones estacionales como sucedía con los episodios Tuina-San Lorenzo-Chulqui.

Se trata de un estadio con más eficiencia laboral que logra un nivel de arraigo más sostenido dentro del Período Arcaico Temprano. Esta Fase Patapatane (ca. 9500 a 8000 AP) se inicia con el uso de artefactos triangulares. En cambio, el clásico patrón lanceolado o foliáceo comienza a aparecer al final de esta fase, por lo que representaría una innovación laboral que emerge de los nuevos hábitos de caza y recolección andinas, cuyas derivaciones se popularizan más tardíamente. La distribución de los sitios principalmente en sectores de praderas en los pisos alta Puna y precordillera, señalaría el inicio de un patrón de ocupación más regularizado de carácter estacional circunscrito a estos pisos altos. La Fase Patapatane no está representada hasta ahora en la Puna Salada, por lo que se podría mantener para esa zona el límite tardío de la Fase Tuina establecido por el primer autor (ver Tabla 2).

El Período Arcaico Medio, ubicado por cronología relativa y en parte absoluta entre $c a$. 8000 a $6000 \mathrm{AP}$, presenta escasos restos de ocupación y los sitios muestran un significativo abandono, lo que coincide con el inicio de intensivas ocupaciones en el litoral. Aunque las causas no se han podido explicar, el registro de sellos de cenizas volcánicas que cubren las ocupaciones tempranas, localizadas en varios de los sitios reportados del sur peruano, norte chileno y Noroeste Argentino, indicarían eventos volcánicos catastróficos que podrían explicar en parte el abandono parcial de las tierras altas en esta amplia región de los Andes, ocurrentes durante el Holoceno, dentro del rango de tiempo de este período.

La reciente datación de la Fase Tambillo, en el Salar de Atacama, en los albores del período, abre nuevas posibilidades para comprender los sucesos del Arcaico Medio en la Puna Salada.

El Período Arcaico Tardío está mejor documentado en ambas punas donde coinciden en mostrar una especializada adaptación laboral en actividades de caza y recolección. Las evidencias son más elocuentes en la Puna Salada, donde los conjuntos de instrumentos y los restos de densas ocupaciones en campamentos expuestos demuestran un uso especializado de los recursos, jalonados entre las vegas y lagunetas del 


\begin{tabular}{|c|c|c|c|c|c|}
\hline Sitio & Referencia & Lab. & Años AC & Fecha absoluta & Muestra \\
\hline \multicolumn{6}{|l|}{ Puna Seca } \\
\hline Asana & Aldenderfer 1958 & Beta-24628 & 7900 & $9580 \pm 130$ & madera \\
\hline Toquepala & Ravines 1972 & Y-1325 & 7900 & $9580 \pm 160$ & carbón \\
\hline Tojo Tojone & Dauelsberg 1983 & Gak-7958 & 7900 & $9580 \pm 1950^{1}$ & carbón \\
\hline Las Cuevas & Santoro y Chacama 1982 & I-12835 & 7590 & $9540 \pm 160$ & carbón \\
\hline Toquepala & Ravines 1972 & Y-1372 & 7540 & $9490 \pm 140$ & carbón \\
\hline Asana & Aldenderfer 1988 & Beta-24630 & 6840 & $8790 \pm 170$ & madera \\
\hline Asana & Aldenderfer 1988 & Beta-18924 & 6580 & $8530 \pm 240$ & madera \\
\hline Hakenasa & Santoro 1986 & I-13287 & 6390 & $8340 \pm 300$ & carbón \\
\hline Las Cuevas & Santoro y Chacama 1984 & I-13128 & 6320 & $8270 \pm 250$ & carbón \\
\hline Caru & Ravines 1967 & Hv-1087 & 6240 & $8190 \pm 130$ & carbón \\
\hline Patapatane & Santoro y Chacama 1984 & I-12837 & 6210 & $8160 \pm 160$ & carbón \\
\hline Asana & Aldenderfer 1988 & Beta-23363 & 5910 & $7860 \pm 110$ & madera \\
\hline Asana & Aldenderfer 1988 & Beta-24629 & 4600 & $6550 \pm 110$ & madera \\
\hline Asana & Aldenderfer 1988 & Beta-25049 & 4900 & $6850 \pm 70$ & madera \\
\hline Asana & Aldenderfer 1988 & Beta-24634 & 4090 & $6040 \pm 90$ & madera \\
\hline Patapatane & Santoro y Chacama 1984 & I-12838 & 2940 & $4890 \pm 130$ & carbón \\
\hline Asana & Aldenderfer 1988 & Beta-24632 & 2660 & $4610 \pm 60$ & madera \\
\hline Asana & Aldenderfer 1988 & Beta-24631 & 2630 & $4580 \pm 120$ & madera \\
\hline Hakenasa & Santoro 1986 & I-13230 & 2430 & $4380 \pm 120$ & carbón \\
\hline Guañure & Santoro y Chacama 1982 & I-11873 & 2380 & $4330 \pm 105$ & carbón \\
\hline Puxuma & Santoro y Chacama 1982 & I-11872 & 2290 & $4240 \pm 95$ & carbón \\
\hline Puxuma 1 & Santoro y Chacama 1982 & I-11645 & 2060 & $4010 \pm 100$ & carbón \\
\hline Quevilque & Santoro Ms & Beta-24355 & 2050 & $4000 \pm 50$ & carbón \\
\hline Piñuta & Santoro y Chacama 1982 & I-11832 & 1800 & $3750 \pm 140$ & carbón \\
\hline Tojo Tojone & Dauelsberg 1983 & Gak-7959 & 1790 & $3740 \pm 130$ & carbón \\
\hline Asana & Aldenderfer 1988 & Beta-23364 & 1690 & $3640 \pm 80$ & carbón \\
\hline Puxuma & Santoro Ms & Beta-24357 & 1560 & $3510 \pm 80$ & carbón \\
\hline Hakenasa & Santoro 1986 & I-13229 & 900 & $2850 \pm 200$ & carbón \\
\hline Tojo Tojone & Santoro Ms & Beta-24358 & 640 & $2590 \pm 80$ & carbón \\
\hline Piñuta & Santoro y Chacama 1982 & I-12834 & 590 & $2540 \pm 180$ & carbón \\
\hline Piñuta & Santoro y Chacama 1982 & I-12833 & 570 & $2520 \pm 90$ & carbón \\
\hline \multicolumn{6}{|l|}{ Puna Salada } \\
\hline Tuina & Núnez 1983a & SI-3112 & 8870 & $10820 \pm 630$ & carbón \\
\hline San Lorenzo 1 & Núñez 1983a & $\mathrm{N}-3423$ & 8450 & $10400 \pm 130$ & carbón \\
\hline San Lorenzo & Spahni & $\mathrm{Hv}-299$ & 8330 & $10280 \pm 120$ & carbón \\
\hline San Lorenzo 1 & Núñez 1983a & $\mathrm{N}-242$ & 8010 & $9960 \pm 125$ & carbón \\
\hline Chulqui 1 & Sinclaire 1985 & Beta- 6845 & 7640 & $9590 \pm 60$ & carbón \\
\hline Tuina 1 & Núñez 1983a & $\mathrm{N}-3424$ & 7130 & $9080 \pm 130$ & carbón \\
\hline Tambillo 1 & Núñez Ms & Beta-25536 & 6640 & $8590 \pm 130$ & carbón \\
\hline Toconce/Confluencia & Aldunate et al. 1986 & Beta-1995 & 6040 & $7990 \pm 125$ & carbón \\
\hline Chulqui 3 & Aldunate et al. 1986 & Beta-7324 & 5230 & $7180 \pm 80$ & carbón \\
\hline Isla Grande & Lanning 1968 & - & 4058 & $6008 \pm 130$ & carbón \\
\hline Chulqui 4 & Aldunate et al. 1986 & Bcta-7323 & 3780 & $5730 \pm 90$ & carbón \\
\hline Confluencia & Lanning 1968 & - & 3430 & $5380 \pm 130$ & carbón \\
\hline Calarcoco & Serracino y Pereyea 1977 & - & 3170 & $5120^{2}$ & colágeno hueso \\
\hline Tulan 51 & Núñez 1981 & $\mathrm{~N}-2486$ & 3040 & $4990 \pm 110$ & carbón \\
\hline Puripica 1 & Núñez 1981 & SI-3113 & 2865 & $4815 \pm 70$ & carbón \\
\hline
\end{tabular}




\begin{tabular}{|c|c|c|c|c|c|}
\hline Sitio & Referencia & Lab. & Años AC & Fecha absoluta & Muestra \\
\hline Chiu Chiu ${ }^{3}$ & Druss 1977 & $1-5173$ & 2715 & $4665 \pm 110$ & carbón \\
\hline Kalina/Los Morteros & Aldunate et al. 1986 & Beta-12977 & 2420 & $4370 \pm 220$ & carbón \\
\hline Tulan 52 & Núñez 1981 & $\mathrm{~N}-2487$ & 2390 & $4340 \pm 95$ & carbón \\
\hline Tulan 52 & Núñez 1981 & $\mathrm{~N}-2488$ & 2320 & $4270 \pm 80$ & carbón \\
\hline Calarcoco & Serracino 1975 & - & 2170 & $4120 \pm 170$ & colágeno apatita \\
\hline Puripica 1 & Núñez 1981 & $\mathrm{CN}-2360$ & 2100 & $4050 \pm 95$ & carbón \\
\hline Kalina/Los Morteros & Aldunate et al. 1986 & Beta-6844 & 2000 & $3950 \pm 50$ & carbón \\
\hline Chiu Chiu ${ }^{4}$ & Druss 1977 & $1-7016$ & 1675 & $3625 \pm 85$ & carbón \\
\hline
\end{tabular}

1 La muestra de carbones obtenidas en los estratos tempranos fue insuficiente, por lo que fue enriquecida con carbones de época más tardía. Debido a esta alteración convenida con el Laboratorio, se citan tres sigmas de desviación estándar (Dauelsberg 1983: 16).

2 La desviación estándar de esta muestra no fue publicada.

3 Esta es la muestra más temprana de una serie de fechas correspondientes al Complejo Chiu Chiu representado por 70 sitios.

$4 \quad$ Esta es la fecha más tardía del Complejo Chiu Chiu.

Tabla 8. Fechas radiocarbónicas no corregidas de sitios arqueológicos de la Puna Seca y Salada (sur Perú-norte de Chile).

Salar de Atacama, quebradas intermedias y alta Puna, incluyendo el curso medio del río Loa, organizados en eficientes circuitos de trashumancia estacional. Se asocia un creciente desarrollo de campamentos semipermanentes, con habitaciones circulares de piedras, en depresiones semisubterráneas, ubicadas en espacios abiertos junto a quebradas, vegas del Salar o en pisos forrajeros más altos, perdiéndose la dependencia a la disponibilidad natural de cuevas y aleros. Esto coincide con un proceso local de domesticación de camélidos y caza especializada, tal como se ha observado en los sitios de Puripica y Tulan, respectivamente, incluido horticultura de quinua en el transecto Tulan.

Para la Puna Seca, aunque la evidencia no es tan explícita, se vislumbra el surgimiento de campamentos estables o semipermanentes en torno a los bofedales sostenidos por una caza especializada y/o posible domesticación de camélidos. Este proceso se ha sugerido considerando la aparición gradual, en el Arcaico Tardío, de nuevos tipos de instrumentos (p.e., puntas escotadas y cuchillos triangulares) que se popularizan en el período siguiente asociado a fragmentos de cerámica inicial y elaboración de objetos de oro. Esto sugiere el desarrollo de una nueva época formativa en las auspiciosas, aunque poco dispensiosas punas de los Andes del Centro Sur. Aquí existió al final del Período Arcaico una densa población que debió transitar hacia un estilo de vida agropastoril temprano, dominando gradualmente el paisaje de las tierras de altura media y altas, en ambas punas, creando las condiciones necesarias para la emergencia de sociedades complejas que caracterizaron a los asentamientos postarcaicos del territorio in toto entre el segundo y primer milenio AC. El registro de densos asentamientos agropastoriles con cerámica imbricada, en el transecto Tulan (Puna Salada), datados en 1200 AC presupone que existieron durante un rango de tiempo más temprano de lo esperado, poblaciones arcaicas tardías que se incorporaron de una manera más neolítica al nuevo y más productivo estilo de vida aldeano-agropastoril. Este proceso parece derivarse de las experiencias de domesticación y horticultura local (Puripica y Tulan), paralelo al arribo de comunidades externas, asumidos estos aportes en una singular combinación cultural y productiva intrapuneña.

Agradecimientos El primer autor ha aportado los datos provenientes de la Puna Salada conjuntamente con la organización de la edición de esta versión corregida del artículo que publicamos en Andean Past 1 (1987). Agradece a los colegas colaboradores participantes de los proyectos en curso en la Subárea Circumpuneña, patrocinados por Universidad del Norte, Smithsonian Institution y FONDECYT (Proyecto 1017-86), de los cuales resumimos algunos de sus aportes más relevantes y pertinentes a la naturaleza de este artículo. El segundo autor agradece la decisiva participación de los colegas del Museo San Miguel de Azapa que han colaborado en el programa de estudio de Tierras Altas de Arica, que ha contado con apoyo financiero de la Universidad de Tarapacá y del National Geographic Society (Proyecto 2623/83, 2983/84). 


\section{REFERENCIAS CITADAS}

ALDENDERFER, M., 1985 Ms. Archaic Period settlement system in Southern Perú. Preliminary report on the 1984 field season, Northwestern University Archaic Proyect.

1988. Middle Archaic Period domestic architecture from Southern Perú. Science 240.

ALDUNATE, C., J. ARMESTO, V. CASTRO y C. VILLAGRAN, 1981. Estudio etnobotánico en una comunidad precordillerana de Antofagasta: Toconce. Boletín del Museo Nacional de Historia Natural 38: 183-223.

ALDUNATE, C., J. BERENGUER, V. CASTRO, L. CORNEJO, J. L. MARTINEZ y C. SINCLAIRE, 1986. Cronología y asentamiento en la región del Loa superior. Dirección de Investigación y Biblioteca, Universidad de Chile, Santiago.

ALVAREZ, L., 1980. Cazadores altoandinos en la costa de Arica. Actas y Trabajos del III Congreso Peruano "El Hombre y la Cultura Andina”, vol. 5: 1029-1031.

ASCHERO, C., 1985. Notas sobre el uso de pigmentos minerales en el sitio CCP-5. Prov. de Santa Cruz, Argentina. En Estudios en arte rupestre, C. Aldunate, J. Berenguer y V. Castro (Eds.), pp. 13-24. Museo Chileno de Arte Precolombino, Santiago.

BAILEY, G., 1983. Hunter-gatherer economy in prehistory. A European perspective. Cambridge University Press, Cambridge.

BIRD, J., 1943. Excavations in Northern Chile. Anthropological Papers of the American Museum of Natural History XXXVIII Part. IV, Nueva York.

BOWMAN, I., 1924. Desert trails of Atacama. American Geographical Society Special Publications 5, Nueva York.

CARDICH, A., 1980. Origen del hombre y la cultura andinos. Historia del Perú, vol. 1. Perú antiguo, pp. 31-156. Editorial Juan Mejía Baca, Lima.

CASHDAN, E. 1983 Territoriality among human foragers: Ecological models and application to four Bushman groups. Current Anthropology 24: 47-66.

CASTRO, M., C. VILLAGRAN y M. KALIN, 1982. Estudio etnobotánico de los Andes del norte de Chile (18-19 S). En Ambiente natural y las poblaciones humanas en los Andes del norte de Chile (Arica, Lat. $18^{\circ} 28^{\prime}$ 'S), E. Bustos y A. Veloso (Eds.), vol. 2, pp. 133-199. UNESCO, Santiago.

CRAIG, A., 1982. Ambiente costero del norte de Chile. Chungara 9: 4-20.

_ 1984. Paleoambiente durante el precerámico nor-chileno: Uso de imágenes Landsat. Chungara 13: 93-98.

1985. Cis-Andean environmental transects: Late Quaternary ecology of Northern and Southern Perú. En Andean ecology and civilization, an interdisciplinary perspective on Andean ecological complementarity, S. Masuda, I. Shimada y C. Morris (Eds.), pp. 21-44. University of Tokio Press, Tokio.

DAUELSBERG, P., 1982. Prehistoria de Arica. Diálogo Andino 1: 31-82.

1983. Tojo Tojone un paradero de cazadores arcaicos en la Sierra de Arica. Chungara 11: 11-30.

DAVIS, E., 1963. The Desert Culture of the western Great Basin: A lifeway of seasonal transhumance. American Antiquity 29: $202-212$.

DENNIS, B., 1987 Ms. Faunal analysis of the bones from Patapatane, Chile. University of Colorado, Boulder.

DRUSS, M., 1977. Computer analysis of Chiu Chiu Complex settlement pattern. El Dorado 2 (3): 51-73.

FERNANDEZ DISTEL, A., 1974. Excavaciones en las cuevas de Huachichocana. Dep. de Tumbaya, Prov. de Jujuy. Relaciones de la Sociedad Argentina de Antropología 7: 101-127.

FRANCIS, P., M. GARDEWEG, C RAMIREZ y D. ROTHERY, 1985. Catastrophic debris avalanche deposit of Socompa volcano, Northern Chile. Geology 13: 601-603.

GRAF-MEIR, K., 1977. Nuevos datos palinológicos del Cuaternario alto de Bolivia. Boletín del Servicio Geológico de Bolivia 1 (1): 1-14.

1981. Palynological investigations of two post-glacial peat bogs near the boundary of Bolivia and Perú. Journal of Biogeography 8: 353-368.

HESSE, B. y P. HESSE, 1979 Ms. Archaic animals explotation in inland Northern Chile. Departamento de Antropología, Smithsonian Institution, Washington D.C.

HESSE, B., 1982. Archaeological evidence for camelid explotation in the Chilean Andes. Säugetierekunde Mitteilungen 30 (3): 201-211.

HESTER, J., 1966. Late Pleistocenic environments and Early Man in South America. The American Naturalist 100: 377-388.

JOHNSON, L., 1978. The Aguas Verdes industry of Northern Chile. En Advances in Andean archaeology, D. Browman (Ed.), pp. 7-39. Mounton Publishers, The Hague-París.

KALIN, M., C. VILLAGRAN y J. ARMESTO, 1982. Flora y relaciones biogeográficas en los Andes del norte de Chile. En El ambiente natural y las poblaciones humanas en los Andes del norte de Chile (Arica, Lat. 18 28' S), F. Bustos y A. Veloso (Eds.), vol. 1, pp. 71-92. UNESCO, Santiago.

KALIN, M., F. SQUEO, J. ARMESTO y C. VILLAGRAN, 1988. Effects of aridity on plant diversity in the Northern Chilean Andes: Results of a natural experiment. Ann. Missouri Bot. Gar. 75. 
VAN KESSEL, J., 1980. Holocausto al progreso. Los aymaras de Tarapaca. En Incidentale Publicaties 16. Centro de Estudios y Documentación Latinoamericanos (CEDLA), Amsterdam.

LANNING, E., 1963. A pre-agricultural occupation on the Central Coast of Perú. American Antiquity 28 (3): 360-371.

1968. Informe previo de las excavaciones realizadas por la Columbia University Field Station durante el año 1967. Revista de la Universidad del Norte II (1): 63-67.

LEE, R. e I. DEVORE, 1968. Man the hunter. Aldine Publishing Company, Chicago.

LE PAIGE, G, 1970. Las industrias líticas de San Pedro de Atacama. Orbe-Universidad del Norte, Santiago.

_ 1975. ¿Se puede hablar de trashumancia en la zona atacameña? Estudios Atacameños 3: 11-16.

LYNCH, T., 1967a. The nature of the Andean Preceramic. Occacional Papers of the Idaho State University Museum 21.

_ 1967b. Quishqui Puncu: A preceramic site in highland Peru. Science 158: 780-783.

_ 1971. Preceramic transhumance in the Callejón de Huaylas. Peru. American Antiquity 36: 139.

- 1973. Harvest timing, transhumance and the process of domestication. American Anthropologist 75: 1254-1259.

1980. Guitarrero Cave: Early Man in the Andes. Academic Press, Nueva York.

- 1981. Zonal complementarity in the Andes: A History of the concept. En Networks of the past: Regional interaction in archaeology. Proceedings of the Twelfth Annual Chacmool Conference, P. Francis y F. Kense (Eds.), pp. 221-231. The Archaeological Asociation of the University of Calgary, Calgary.

1983. The paleoindians. En Ancient South Americans, J. Jennings (Ed.), pp. 87-138. W. H. Freeman, San Francisco.

- 1986. Climate change and human settlement around the late glacial laguna de Punta Negra, Northern Chile: The preliminary results. Geoarchaeology 1: 146-161.

LYNCH, T. y K. KENNEDY, 1970. Early human cultural and skeletal remains from Guitarrero Cave, Northern Peru. Science 169: 1307-1309.

MENGHIN, O. y G. SCHROEDER, 1957. Un yacimiento en Ichuna (Depto. Puno, Perú) y las industrias precerámicas de los Andes Centrales y Septentrionales. Acta Prehistórica 1: 41-57.
MONTANE, J., 1972. Las evidencias del poblamiento temprano de Chile. Pumapunku 5: 40-53.

MUÑOZ, I. y J. CHACAMA, 1982. Investigaciones arqueológicas en las poblaciones precerámicas de la costa de Arica. Documentos de Trabajo 2: 3-97.

NIEMEYER, H. y V. SCHIAPPACASSE, 1963. Investigaciones arqueológicas en las terrazas de Conanoxa, valle de Camarones (Provincia de Tarapacá). Revista Universitaria año XLVIII, Anales de la Academia Chilena de Ciencias Naturales 26: 101-166.

1968. Tres industrias líticas de la Puna de Atacama. Parte I: El yacimiento Miscanti Sur. Revista Universitaria año LIII. Anales de la Academia Chilena de Ciencias 31: 133-144.

1976. Los yacimientos arqueológicos de la laguna Meniques. En Homenaje al Dr. Gustavo Le Paige, H. Niemeyer (Ed.), pp. 31-57. Universidad del Norte, Antofagasta.

1977. Investigaciones de un sitio temprano de cazadores recolectores arcaicos en la desembocadura del valle de Camarones. Actas del VII Congreso de Arqueología de Chile, vol. 1: pp. 115-118.

NOGAMI, M., 1982. Circulación atmosférica durante la última época glacial en los Andes. Revista de Geografía Norte Grande 9: 41-48.

NUÑEZ, L., 1975. Dinámica de grupos precerámicos en el perfil costa altiplano, norte de Chile. Estudios Atacameños 3: 59-74.

1980a. Cazadores tempranos en los Andes Meridionales. Evaluación cronológica de las industrias líticas del norte de Chile. Boletín de Antropología Americana 2: 87-120.

— 1980b. Hipótesis de movilidad trashumántica en la Puna de Atacama: Quebrada de Tulan (nota preliminar). Actas del V Congreso Nacional de Arqueología Argentina, vol. 2, pp. 19-46. San Juan.

NUÑEZ, L., 1981. Asentamientos de cazadores tardíos de la Puna de Atacama: Hacia el sedentarismo. Chungara 8: 137-168.

_ 1983a. Paleoindio y Arcaico en Chile: Diversidad, secuencia y procesos. Ediciones Cuicuilco, Serie Monografías, México D. F.

— 1983b. Paleoindian and Archaic cultural periods in the arid and semiarid regions of Northern Chile. En Advances in World Archaeology vol. 2, pp. 161-203. Academic Press, Nueva York.

1984 Ms. Cazadores tempranos de Tuina: Correlaciones en el Area Centro Sur Andina.

1986 Ms. El período lítico en el extremo occidental de América del Sur (sur Perú, Bolivia, noroeste de Argentina y Chile). 
1988 Ms. Informe Proyecto FONDECYT 1017-86.

NUÑEZ, L. y T. DILLEHAY. 1979. Movilidad giratoria, armonía social y desarrollo en los Andes Meridionales: Patrones de tráfico e interacción económica (ensayo). Universidad del Norte, Antofagasta.

NUÑEZ, L. y C. MORAGAS, 1977-1978. Ocupación arcaica temprana en Tiliviche, norte de Chile (I Región). Boletín Museo Arqueológico La Serena 16: 52-76.

NUÑEZ, L., J. VARELA y R. CASAMIQUELA, 1983. Ocupación paleoindia en Quereo (IV Región): Una reconstrucción multidisciplinaria en el territorio semiárido de Chile. Universidad del Norte, Antofagasta.

NUÑEZ, L., V. ZLATAR y P. NUÑEZ, 1975. Un circuito trashumántico entre la costa de Pisagua y el borde occidental de la Pampa del Tamarugal. Estudios Atacameños 3: 49-52.

OCHSENIUS, C., 1986. La glaciación Puna durante el Wisconsin, deglaciación y máximo lacustre en la tradición WisconsinHoloceno y refugios de la megafauna postglaciales en la Puna y Desierto de Atacama. Revista de Geografía Norte Grande 13: 29-58.

ORLOVE, B., 1977. Integration through production: The use of zonation in Espinar. American Ethnologist 4: 84-101.

PONCE, C., 1970. Las culturas Wankarani y Chiripa y sus relaciones con Tiwanaku. Academia Nacional de Ciencias de Bolivia Publicación 25, La Paz.

RAVINES, R., 1967. El abrigo de Caru y sus relaciones con otros sitios tempranos del sur de Perú. Ñawpa Pacha 5: 39-57.

_ 1972. Secuencia y cambios en los artefactos líticos del sur de Perú. Revista del Museo Nacional XXXVIII: 133-184.

RICK, J.,1980. Prehistoric hunters of the High Andes. Academic Press, Nueva York.

- 1983. Cronología, clima y subsistencia en el Precerámico peruano. Colección Mínima, Instituto Andino de Estudios Arqueológicos, Lima.

SANTORO, C., 1986. Antiguos cazadores de la Puna. En Culturas de Chile. J. Hidalgo, H. Niemeyer, V. Schiappacasse, C. Aldunate e I. Solimano, Eds. Editorial Andrés Bello, Santiago.

_ 1987. Settlement patterns of Holocene hunting and gathering societies in the South Central Andes. Tesis de Maestría. Cornell University, Ithaca.

_- Ms. Excavaciones en sitios arcaicos de la Puna Seca, norte de Chile.

SANTORO, C. y J. CHACAMA, 1982. Secuencia cultural de las tierras altas del Area Centro Sur Andina. Chungara 9: 22-45.
- 1984. Secuencia cultural de las tierras altas del extremo norte de Chile. Estudios Atacameños 7: 85-103.

SANTORO, C. y P. DAUELSBERG, 1985. Identificación de indicadores tempo-culturales en el arte rupestre del extremo norte de Chile. En Estudios en arte rupestre, C. Aldunate, J. Berenguer y V. Castro (Eds.), pp. 69-86. Museo Chileno de Arte Precolombino, Santiago.

SANTORO, C. y L. NUÑEZ, 1987. Hunters of the Dry Puna and the Salt Puna in Northern Chile. Andean Past 1: 54-109.

SERRACINO, G., 1975. Los movimientos de los cazadores recolectores en la Cordillera de los Andes (entre la latitud $21^{\circ}$ y $26^{\circ}$ y longitud $67^{\circ} 00^{\prime}$ y $70^{\circ} 22^{\prime}$ ). Estudios Atacameños 3: $17-44$.

SERRACINO, G. y F. PEREYEA, 1977. Tumbre: Sitios estacionales en la industria Tambillense. Estudios Atacameños 5: 5-17.

SCHIAPPACASSE, V. y H. NIEMEYER, 1975. Apuntes para el estudio de la trashumancia en el valle de Camarones (Prov. de Tarapacá), Chile. Estudios Atacameños 3: 53-57.

- 1984. Descripción y análisis interpretativo de un sitio arcaico temprano en la quebrada de Camarones. Publicación Ocasional del Museo Nacional de Historia Natural 41.

SINCLAIRE, C., 1985. Dos fechas radiocarbónicas del alero de Chulqui, río Toconce: Noticia y comentario. Chungara 14: 71-79.

SPANHI, J., 1967. Recherches archéologiques a l'embouchure du Río Loa (côte du Pacifique-Chili). Journal de la Société des Americanistes 56 (1): 179-252.

TROLL, C., 1958. Las culturas superiores andinas y el medio geográfico. Revista del Instituto de Geografía 5.

TRUE, D., 1975. Early maritime cultural orientations in prehistoric Chile. En Maritime adaptations of the Pacific, R. Castel y G. Quimby (Eds.), pp. 89-143. Mouton Publishers, The Hague.

TRUE, D. y H. CREW, 1980. Archaeological investigations in Northern Chile: Tarapacá 2A. En Prehistoric trails of Atacama. Archaeology of Northern Chile, C. Meighan y D. True (Eds.), pp. 59.50. Monumenta Archaeologica 7. University of California, Los Angeles.

TRUE, D. y L. GILDERSLEEVE, 1980. Archaeological investigations in Northern Chile: Tarapacá 18. En Prehistoric trails of Atacama, Archaeology of Northern Chile, C. Meighan y D. True (Eds.). Monumenta Archaeologica 7. University of California, Los Angeles.

VILLAGRAN, C., J. ARMESTO y M. KALIN, 1981. Vegetation in a high Andean transect between Turi-Cerro León in Northern Chile. Vegetation 48 (1): 3-16.

VILLAGRAN, C., M. KALIN y J. ARMESTO, 1982. La vegetación de una transecta altitudinal en los Andes del norte de Chile $\left(18^{\circ}-19^{\circ} \mathrm{S}\right)$. En El ambiente natural y las 
poblaciones humanas en los Andes del Norte Grande de Chile (Arica Lat. $18^{\circ} 28^{\prime} \mathrm{S}$ ), vol. I, E. Bustos y A. Veloso (Eds.). UNESCO, Santiago.

WALTER, H., 1966. Grabung mound Huancarani, Buträge zur archäologie Boliviens. Baessler-Archiv, Neue Folge, Beiheltt 4: 15-99.
WILLEY, G., 1971. An introduction to American archaeology, vol. 2. Englewood Cliffs, N. J. Prentice-Hall.

YBERT, J. y P. MIRANDA, 1984. Análisis palinológico de un corte del Sajama. Actas del Segundo Congreso Geológico de Bolivia, pp. 691-695. La Paz. 